\title{
FACULDADE DE SAÚDE PÚBLICA DA UNIVERSIDADE DE SÃO PAULO
}

\section{Educação Ambiental para Promoção da Saúde com Trânsito Solidário}

Sandra Costa de Oliveira

Dissertação apresentada ao Programa de Pós-Graduação em Saúde Pública para obtenção do título de Mestre em Ciências.

Área de concentração: Serviços de Saúde Pública.

Orientadora: Prof ${ }^{a}$ Associada Maria Cecilia Focesi

Pelicioni

São Paulo 


\section{Educação Ambiental para Promoção da Saúde com Trânsito Solidário}

Sandra Costa de Oliveira

Dissertação apresentada ao Programa de Pós-Graduação em Saúde Pública para obtenção do título de Mestre em Ciências.

Área de concentração: Serviços de Saúde Pública.

Orientadora: Prof ${ }^{\mathrm{a}}$ Associada Maria Cecilia Focesi Pelicioni

São Paulo 
"A gente tem que sonhar senão as coisas não acontecem"

Oscar Niemayer 


\section{AGRADECIMENTOS}

Em primeiro lugar a Deus e aos meus pais Maria Conceição Costa (in memoriam) e Bento Lopes de Oliveira (in memoriam), pois sem eles eu não estaria aqui para deixar minha pequena contribuição para a sociedade.

À minha irmã Celia e meu sobrinho Eduardo que são a minha família querida.

Ao Michel Mazard, inventor do site Eco-carroagem que foi um instrumento importante para que eu pudesse realizar parte da minha pesquisa. Marido, amigo, companheiro de todas as horas por ter suportado meus momentos difíceis e por me incentivar a continuar sempre, ajudando-me e valorizando-me. Te amo muito.

Ao amigo Edson Vanderlei Zombini que sempre que eu precisei de um socorro ele estava ali pronto para me ajudar.

À minha querida amiga Edna Faria Assini que um dia me disse se eu precisasse de ajuda para alguma atividade do mestrado eu poderia chamá-la e foi o que eu fiz. Agradeço muito sua disponibilidade e amizade.

Ao Prof. Dr Delsio Natal que sempre foi um grande amigo e me incentivou muito a dar continuidade nos meus estudos fazendo o mestrado. E na minha qualificação esteve presente e contribuiu muito para o resultado final.

Ao Prof. Dr Marcos Reigota que sempre que eu precisei de alguma informação, mandava emails e o mesmo prontamente respondia com muita atenção e carinho.

À Prof ${ }^{a}{ }^{-} r^{a}$ Sonia Chebel Mercado Sparti que me foi apresentada pelo Prof. Reigota e me ajudou de uma forma tão carinhosa e humana que não tenho palavras para dizer o quanto estou grata por sua contribuição em minha pesquisa. Desculpe-me por ligar tão tarde em sua casa.

À Sra Maria Helena Sponton Coordenadora do Serviço de Humanização da Instituição Hospitalar onde realizei a pesquisa, que deu total apoio ao 
projeto e sempre esteve presente quando das minhas necessidades dentro da Instituição.

À funcionária Bruna Morante, assessora da Coordenadoria do Serviço de Humanização que me ajudou muito fazendo a ponte entre os funcionários da Instituição Hospitalar que participaram da pesquisa e eu.

Aos funcionários da Pós-Graduação, do Serviço de Alunos e do Comitê de Ética da Faculdade de Saúde Pública que me ajudaram prontamente quando eu precisei de qualquer informação para o bom desempenho e cumprimento dos prazos referentes ao mestrado.

Aos funcionários do Departamento de Prática de Saúde Pública, Antônio Carlos dos Santos, Bianca Benedeti Mazini, Edina Aparecida Condé Arouca Paladini, Fernando Miguez Vargas Junior, Livia Mara Silva Rosa, Maria Aparecida do Nascimento Soares Alves, Sônia Francisca Martins e Valdívia Moreira Romariz pela atenção carinho e disposição em ajudar-me em tudo o que eu precisei durante o processo.

Às queridas amigas Paula Cristina Ischkanian, Elaine Cristina Silva, Thais Guerreiro, leda Borges, Roberta Oliveira, Ludmila, Miriam e Silvana Ribeiro pelo carinho e amizade.

À Faculdade de Saúde Pública por ter me aceito como aluna de PósGraduação.

E à CAPES pela concessão da bolsa de estudos que muito contribuiu para a realização deste trabalho. 


\section{AGRADECIMENTOS ESPECIAIS}

À minha querida orientadora $\operatorname{Prof}^{\mathrm{a}} \mathrm{Dr}^{\mathrm{a}}$ Maria Cecilia Focesi Pelicioni pois sem ela e seu carinho, dedicação, paciência, amor, competência, motivação eu não teria conseguido chegar onde cheguei.

Minha orientadora é o maior exemplo de que vale a pena lutar para um mundo melhor por seus valores e conhecimentos que nos são trazidos.

Agradeço ainda por me enxergar entre tantos alunos (as) que como eu almejam fazer um mestrado com qualidade e determinação.

Agradeço por ter permitido conhecer toda a sua família e conviver com pessoas tão maravilhosas seus filhos, netos, genros, irmãs, amigos.

Agradeço sua filha Andrea Focesi Pelicioni por sua gentileza de sempre ter me avisado dos eventos que aconteceram em São Paulo e no Brasil, ligados a sustentabilidade e mobilidade urbana, no decorrer desses dois anos.

Agradeço também ao Prof. Américo Colli Pelicioni por estar junto em todos os momentos. Nunca esquecerei o dia da minha qualificação em que ele ajudou-me quando fui ensaiar a apresentação e disse muitas coisas que eu deveria falar na hora, uma prova de carinho como essa não existe. Quando eu estava apresentando lembrei-me de algumas informações, que ele disse; outras, não, por conta da ansiedade que nos toma no momento. 


\section{APRESENTAÇÃO}

Minha vida mudou muito desde que eu vim para São Paulo no ano de 2006. Em um primeiro momento eu não sabia o que fazer e nem por onde começar.

Um dia, passando pela Rua Theodoro Sampaio descobri a Faculdade de Saúde Pública (USP) que anunciava um evento sobre resíduos sólidos. Eu tinha feito na graduação alguns trabalhos sobre resíduos e achava a temática muito interessante até aquele momento. Mesmo sem ter feito nenhuma inscrição, tomei coragem, entrei na faculdade e fiz a inscrição naquele momento e participei do primeiro evento fora de minha cidade, até então, Ubatuba. O melhor foi quando me falaram que tinha direito a um certificado de participação. Quando peguei e vi um certificado pela USP senti uma emoção e pensei: chegou o meu momento.

Atualmente, sou mestranda da Faculdade de Saúde Pública da Universidade de São Paulo, da qual tenho muito orgulho, pois jamais eu tinha imaginado fazer mestrado na minha vida. Porém antes de ingressar no mestrado eu fiz duas especializações: uma, em Administração Hospitalar, e outra, em Saúde Pública, ambas na mesma faculdade.

Nasci na cidade de Piracicaba, em 19 de julho de 1965. Sou a filha mais velha de Bento Lopes de Oliveira, um Policial Militar e de Maria Conceição Costa, prendas domésticas (ambos in memoriam). Tenho uma irmã chamada Célia Costa de Oliveira e um sobrinho chamado Eduardo de Oliveira Guedes que são minha paixão.

Quando eu fazia o $2^{\circ}$ grau demorei para concluir o ensino médio, por falta de motivação. Fiquei alguns anos começando o ensino médio e deixando no meio do ano até que:

Em 1999, resolvi fazer supletivo de segundo grau em uma escola particular, onde o método de ensino era o método Positivo. Em 1 ano e meio conclui o curso. Depois disso, comecei a me interessar pelos estudos. Nessa 
época eu trabalhava na Prefeitura Municipal de Ubatuba, no Departamento de Turismo.

Nesse Departamento de Turismo, conheci duas pessoas que naquela época já faziam Faculdade de Administração com Habilitação em Hotelaria e Turismo e os mesmos me incentivaram a dar continuidade aos estudos. Era mais ou menos no final do ano 2000, que foi quando eu conheci o Michel, meu marido, mais exatamente no dia 12 de novembro de 2000.

Resolvi então prestar vestibular no final de 2001 na Universidade de Taubaté (UNITAU) e no início de 2002 comecei a cursar a Universidade. O bom é que o campus era em Ubatuba e isso me facilitou muito, pois Taubaté fica a $90 \mathrm{Km}$ de Ubatuba, ou seja, $2 \mathrm{~h} 30$ de ônibus.

Antes de tudo isso, trabalhei no Banco Bradesco no ano de 1985 e, no início da década de 1990, comecei a trabalhar na Prefeitura, onde fiquei por 12 anos passando pelos cargos de Encarregada de Setor, Secretaria de Gabinete e Assessora de Gabinete, todos cargos comissionados.

Os quatro anos de Faculdade foram muito ativos participei de Iniciação Científica nos quatro anos e de todos os eventos que a faculdade dispunha.

Por outro lado tiveram também algumas turbulências. Em 2004, quando eu estava no 3ำ ano, minha mãe veio a falecer, o que foi muito difícil e em 2005 foi meu pai quem faleceu. Confesso que me deu até vontade de desistir, mas eu já estava no último ano e com a ajuda de Deus e de alguns colegas de classe, fui ganhando forças para continuar.

Meu estágio de conclusão da Graduação foi na Santa Casa de Ubatuba onde o meu projeto tinha como objetivo, estudar a logística de materiais e medicamentos daquele hospital, tudo isso incentivado pela minha então orientadora Prof $^{a}{ }^{-} r^{a}$ Quesia Postigo Kamimura.

Foi a partir daí, que nasceu minha paixão pela área da saúde. Colei grau em março de 2006 e em Abril do mesmo ano comecei a fazer uma Especialização em Administração Hospitalar, na Faculdade de Saúde Pública (USP), conforme citei acima. 
Minha escolha pela Faculdade de Saúde Pública se deu por conta de ser da Universidade de São Paulo. Foi uma Especialização bem difícil, com 595 horas/aula, eu frequentava as aulas de segunda à sexta-feira, das 18 às $21 \mathrm{~h}$.

Nesse período conheci uma docente do Departamento de Epidemiologia Prof ${ }^{a}{ }^{-} r^{a}$ Maria Lúcia Lebrão, que me convidou para trabalhar em um projeto em parceria com a Prefeitura de São Paulo, por um período de 6 meses. Após o término deste trabalho e a conclusão do curso, fui convidada para ser secretária do Curso Interdisciplinar em Saúde Pública da Faculdade de Saúde Pública (FSP/USP). Fiquei por mais 1 ano e meio neste trabalho que gostei muito e resolvi, no ano de 2009, fazer como aluna, o curso de Especialização Interdisciplinar em Saúde Pública.

Conheci a Prof ${ }^{a}$ Cecilia neste período. Ela orientava uma aluna do Curso de Saúde Pública e eu fazia a ponte entre alunos e orientadores. Um certo dia após ter terminado o curso, o qual eu secretariava encontrei-a e ela me presenteou com um livro. Enquanto acontecia o processo seletivo para ingressar no Curso de Saúde Pública eu fiquei na espera pelo resultado.

Consegui fazer o curso e a Prof ${ }^{a}$ Cecilia me orientou no projeto intitulado "Educação ambiental para promoção da saúde com vistas para um trânsito saudável".

Em meados de 2010, terminei a especialização e em outubro do mesmo ano prestei a prova de proficiência para o Mestrado, passei e comecei a pósgraduação no ano de 2011, dando continuidade no projeto começado na Especialização, no qual o Michel meu marido, tem uma parcela importante, pois foi ele quem fez o site Eco-carroagem, o qual se tornou um dos instrumentos de meu projeto.

Hoje estou aqui contando um pouco de minha história, mas, somente das coisas que tiveram grande relevância em minha vida. Se me perguntarem se eu quero continuar os estudos tenho certeza que sim mas isso é uma outra história. 


\section{RESUMO}

Oliveira Costa S. Educação Ambiental para promoção da Saúde com Trânsito Solidário \{dissertação de mestrado\}. São Paulo: Faculdade de Saúde Pública da USP; 2013.

A poluição do ar é um fenômeno decorrente, principalmente, da atividade humana em vários setores, agravada pelo crescimento populacional e econômico, pelas grandes inovações tecnológicas e a rápida industrialização, que tornaram-na uma preocupação crescente, pois seus efeitos são claramente perceptíveis e sentidos por toda a sociedade, sejam crianças, adultos e idosos. Um dos maiores problemas ambientais atualmente é a poluição do ar. Os veículos automotores são a principal fonte de poluição atmosférica e de ruído na cidade de São Paulo como também, de outras regiões metropolitanas do país. Uma das alternativas que poderá minimizar este problema é a implantação de um Programa de Carona Solidária. O objetivo deste estudo portanto, foi: a) identificar os motivos que levam ou não as pessoas a participarem de um Programa de Carona Solidária na cidade de São Paulo-SP; b) verificar seus conhecimentos, opiniões e percepções sobre as relações entre a saúde e o meio ambiente; e em particular sobre o uso do automóvel e a poluição ambiental e c) verificar em que medida essas percepções poderão influenciar a decisão em participar de um Programa dessa natureza. A metodologia utilizada nesta pesquisa foi a quali-quantitativa, tendo sido aplicado um questionário voltado para os funcionários de uma Instituição Hospitalar e também foram realizadas entrevistas com profissionais das áreas de saúde e meio ambiente. Conclusão: todos os participantes da pesquisa demonstraram ter preocupação com a qualidade do meio ambiente, pensando nas futuras gerações. No entanto, nas questões práticas como compartilhar o automóvel para participar da Carona Solidária, verificou-se um certo desinteresse. O grupo não está preparado para compartilhar o automóvel principalmente por razões socioculturais. Dar e receber carona de pessoas conhecidas, também é um fator que influencia a adesão ao Programa, para que 
os entrevistados sintam segurança ao participar. Na opinião dos entrevistados a implementação da Carona Solidária será mais efetiva se for realizada em empresas, escolas, universidades ou outras instituições onde as pessoas já se conhecem. Possuir um carro constiui-se ainda em um valor para uma parcela considerável da população entrevistada. A dificuldade em estabelecer relação entre saúde e ambiente também interfere na adesão dos profissionais mesmo considerando uma iniciativa interessante. Acredita-se que a educação ainda seja o melhor caminho para que ocorram mudanças de atitudes. 


\section{ABSTRACT}

Oliveira Costa S. Educação Ambiental para Promoção da Saúde com Trânsito Solidário./Environmental Education for promotion of Health by Sympathetic Traffic \{dissertation\}. São Paulo (BR): Faculdade de Saúde Pública da Universidade de São Paulo; 2013.

Air pollution is a phenomenon mainly derived from human activity in several sectors, aggravated by economy and population growth, by the large technological innovations and the rapid industrialization, which made it a growing concern, for its effects are clearly perceptible and felt by the entire society, whether they are children, adults or elderly. One of the major environmental problems is currently air pollution. Automotive vehicles are the main source of atmospheric pollution and noise in the city of São Paulo as well as in the other metropolitan regions of the country. One alternative to possibly minimize this problem is the implementation of a Sympathetic Car Ride Program. The objective of this study was therefore: a) to identify the reasons for people participating or not in a Sympathetic Car Ride Program in São Paulo City-SP; b) to verify their knowledge, opinions and perceptions about the relationship between health and environment; and particularly about the use of the automobile and environmental pollution and c) to verify in to what extent these perceptions would influence their decision to take part in a Program of this nature. The quail-quantitative research methodology was used: a hospital clerk oriented questionnaire was applied to the workers of a health institution and so were interviews with health and environment professionals. Conclusion: all the participants surveyed demonstrated to have preoccupation with the quality of the environment when thinking on future generations. Nonetheless, on practical issues such as sharing the automobile to participate in the Sympathetic Car Ride, a certain lack of interest was verified. The group showed not to be prepared to share the automobile mainly for socio-cultural reasons. To give and to get a ride from known people is also a factor that influences the adhesion to the Program in order that the interviewees feel safe 
when participating. In the interviewees' opinion the implementation of the Sympathetic Ride will be more effective if it is carried out in companies, schools, universities or other institutions where people already got to know one another. A considerable part of the interviewed population still places high value on owning a car. The difficulty in establishing a relationship between health and environment also interferes in the adhesion of the professionals even though they consider it to be an interesting initiative. Education is still believed to be the best way in order that attitude change occurs. 


\section{ÍNDICE}

1 - INTRODUÇÃO

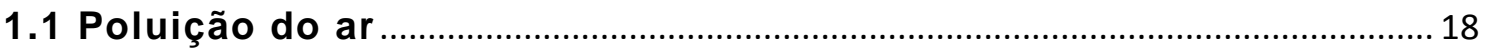

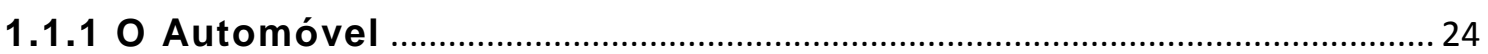

1.2 As Mudanças Climáticas, O Aquecimento Global e a Saúde ................ 32

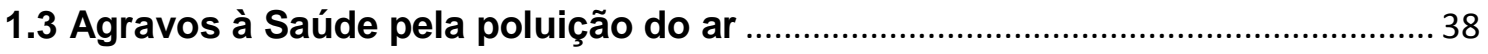

1.4 A Poluição do ar e os veículos automotores …................................................... 45

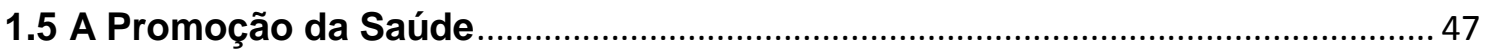

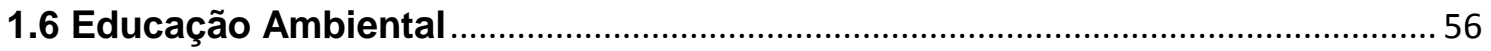

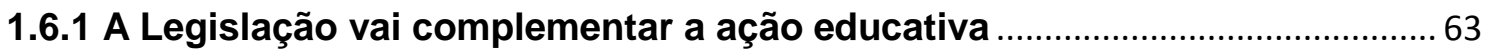

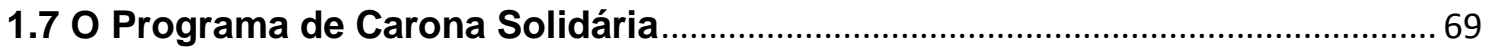

1.8 A Sociedade de Consumo

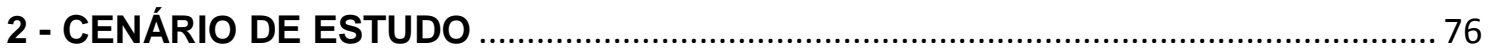

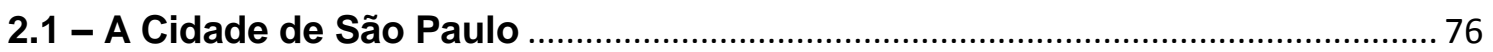

2.2 - O Instituto do Câncer do Estado de São Paulo (ICESP) ………....................... 78

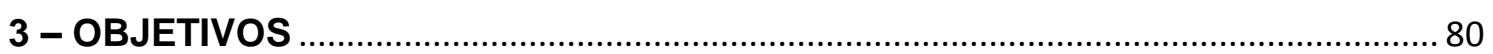

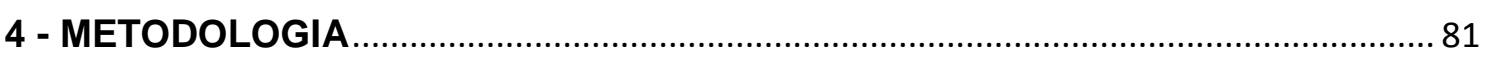

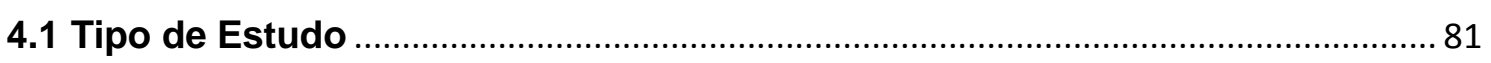

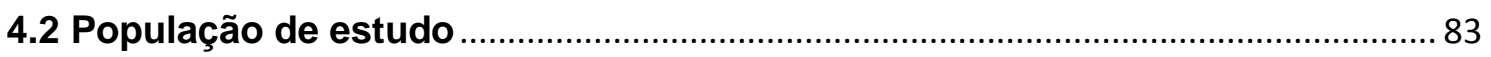

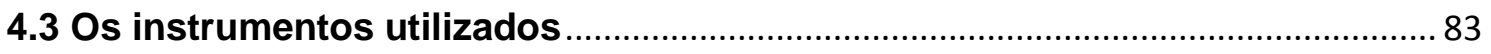

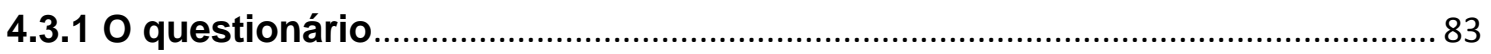

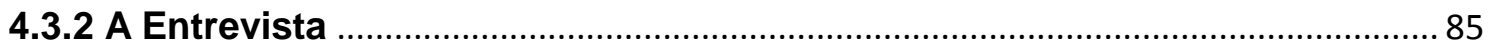

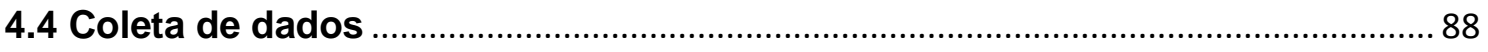

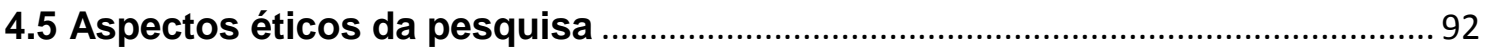

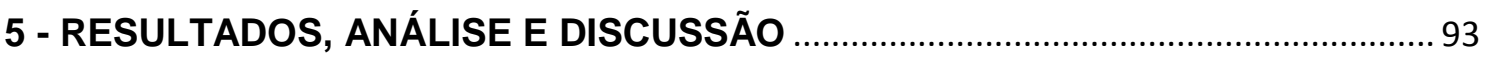

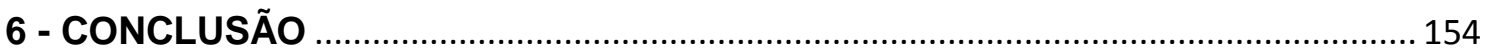

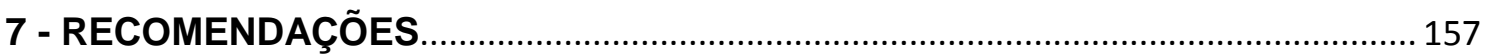

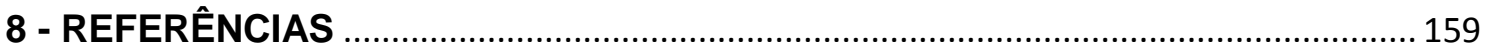

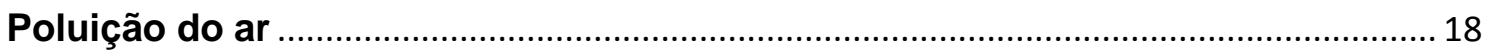

\section{ANEXOS}




\section{LISTA DE QUADROS E FIGURAS}

Quadro I Distribuição de combustíveis utilizados na cidade de São Paulo, em 2007

Quadro II Fontes e características dos principais poluentes na atmosfera 54

Figura 1 Congestionamento causado pelos automóveis na cidade de São Paulo

Figura 2 A estrutura vertical da atmosfera

Figura 3 Instituto do Câncer do Estado de São Paulo - ICESP

Figura 4 Snowball sampling ou "Bola de Neve"

Figura 5 Causas de preocupação com o Meio Ambiente pelos entrevistados 94

Figura 6 Problemas ambientais mais importantes da cidade de São Paulo 96

Figura 7 Problema de saúde relacionado a problemas ambientais relatados pelos entrevistados 


\section{LISTA DE QUADROS E FIGURAS}

Figura 8 Doenças e sintomas apresentados por familiares citados como decorrência da Poluição do Ar na cidade de São Paulo

99

Figura 9 Conhecimento sobre Transporte Compartilhado ou Carona Solidária

Figura 10 Conhecimento sobre Transporte Compartilhado ou Carona Solidária. Sim O que? 102

Figura 11 Opinião dos respondentes sobre Transporte Compartilhado ou Carona Solidária 104

Figura 12 Razões de ausência de cadastro anterior em site de carona 107

Figura 13 Opiniões sobre o site de carona para adesão de outras pessoas 108

Figura 14 Fatores relacionados à segurança dos participantes de um Programa de Carona Solidária 109

Figura 15 Em relação a possuir ou não automóvel 


\section{1 - INTRODUÇÃO}

Atualmente, entre vários conflitos da sociedade, a poluição do ar tem incomodado a população. Esse fenômeno é decorrente, principalmente, da atividade humana em vários setores, agravada pelo crescimento populacional e econômico, pelas grandes inovações tecnológicas e a rápida industrialização, que tornaram-na uma preocupação crescente, pois seus efeitos são claramente perceptíveis e sentidos por toda a sociedade, sejam crianças, adultos e idosos.

A poluição do ar acompanha o ser humano desde os mais remotos tempos, quando seus antepassados descobriram o fogo. $\mathrm{O}$ uso controlado do fogo talvez tenha sido sua primeira grande intervenção ambiental, pois, ao prover calor para seu conforto e proteção, gerava em seu abrigo uma atmosfera tóxica (ASSUNÇÃO e MALHEIROS, 2005, p.135).

Estudos arqueológicos mostram que o uso do fogo nas cavernas oferecia risco de exposição aos homens pré-históricos, uma vez que se tratava de ambientes confinados (WHO, 1999).

A utilização intensiva do petróleo nas indústrias de carvão, nas termoelétricas e no transporte automotivo, se constitui, atualmente, na grande fonte móvel de poluição atmosférica dos centros urbanos, no mundo todo contribuindo para o aumento dos riscos para a saúde da população e para 0 meio ambiente em geral (WHO, 1999).

Na América Latina merece destaque a poluição do ar da cidade do México, da cidade de São Paulo, do Rio de Janeiro, de Porto Alegre, de Belo Horizonte, de Recife e de Santiago do Chile que é causada entre outras coisas, pelo excesso de veículos automotores que circulam diariamente pelas ruas e avenidas das cidades. 


\subsection{Poluição do ar}

A poluição do ar é considerada um problema mundial, ocasionando concentração de poluentes na atmosfera que ultrapassam o limite da capacidade de autodepuração do ecossistema, causando problemas como 0 efeito estufa e a redução da camada de ozônio.

Há pelo menos três décadas, a poluição do ar gera apreensão aos habitantes da Região Metropolitana de São Paulo (RMSP). No início dos anos de 1980, pesquisadores da Faculdade de Medicina da Universidade de São Paulo (FMUSP) criaram um Centro de Pesquisas sobre os efeitos deletérios dos poluentes gerados pelos motores dos veículos - o Laboratório de Poluição Atmosférica Experimental (LPAE). Os estudos experimentais, realizados em câmaras de intoxicação ou no meio ambiente, mostraram mudanças importantes no aparelho respiratório de ratos com alteração das estruturas e perda da função das células e das estruturas responsáveis pelo mecanismo de defesa do sistema respiratório (PEREIRA et al 2010, p.157).

Segundo os mesmos autores, uma vez demonstrados os efeitos adversos dos poluentes do ar sobre os ratos, o passo seguinte foi investigar qual é o impacto dos poluentes na saúde dos habitantes da cidade de São Paulo.

As crianças e os idosos são identificados como os grupos etários mais suscetíveis aos efeitos da poluição atmosférica. Na década de 1990, as primeiras estimativas dos efeitos da poluição do ar mostraram que a mortalidade total de idosos estava diretamente associada à variação do material particulado inalável.

Estudos também têm demonstrado a associação de poluentes com 0 aumento no número de atendimentos em pronto-socorro por doenças respiratórias em idosos, por arritmia cardíaca e doença isquêmica do coração. Recentemente, o Laboratório de Poluição Atmosférica Experimental (LPAE) da Faculdade de Medicina da Universidade de São Paulo demonstrou que os efeitos dos poluentes nas doenças cardiovasculares se manifestam também 
em adultos e que as mulheres podem ser mais acometidas que os homens (LPAE, 2007).

Outro ponto importante é a possibilidade de encontrar alterações clínicas e metabólicas, que são precursoras de doenças respiratórias e cardiovasculares entre indivíduos sadios, mas expostos aos poluentes do ar. Esse foi o caso do estudo realizado em 2000 pelo mesmo grupo que mostrou controladores de tráfego da Companhia de Engenharia de Tráfego (CET), da Prefeitura Municipal de São Paulo, com alterações da pressão arterial e de marcadores inflamatórios sanguíneos em dias mais poluídos.

Segundo TOLEDO (2010 p.21), desde a década de 1970, a Companhia de Tecnologia de Saneamento Ambiental (CETESB) iniciou o monitoramento das concentrações de $\mathrm{SO}_{2}$ e fumaça no ar. No entanto, foi apenas na década de 1990, que este assunto ganhou importância.

Na Região Metropolitana, a poluição do ar é até hoje monitorada pela Companhia de Tecnologia de Saneamento Ambiental (CETESB), através de 22 estações fixas de monitoramento que medem as concentrações dos poluentes: monóxido de carbono, dióxido de enxofre, óxidos de nitrogênio, material particulado e ozônio. As medições de dióxido de enxofre ( $\left.\mathrm{SO}_{2}\right)$ e fumaça começaram a ser realizadas a partir de 1973. O monitoramento automático da qualidade do ar no município iniciou-se a partir de 1981, sendo que em 1999, teve início o monitoramento manual de material particulado fino (PM2,5), o que ainda não ocorre de maneira sistemática.

Até a década de 1980, a poluição do ar em São Paulo era de origem predominantemente industrial. Nesta época, as indústrias automobilísticas, química, siderúrgica, têxtil e alimentícia fixadas no município alavancavam a economia. 
$\mathrm{Na}$ década de 1990, o aumento do controle das emissões industriais e mudanças na ocupação do solo fizeram com que muitas destas indústrias se transferissem para outras áreas do Estado. Atualmente, a poluição emitida pela frota veicular é a principal fonte de poluição atmosférica (TOLEDO, 2010, p.21).

Definido pela CETESB (2011), poluente atmosférico é toda e qualquer forma de matéria ou energia com intensidade e em quantidade, concentração, tempo ou características em desacordo com os níveis estabelecidos em legislação, e que tornem ou possam tornar o ar impróprio, nocivo ou ofensivo à saúde, inconveniente ao bem-estar público, danoso aos materiais, à fauna e à flora ou prejudicial à segurança, ao uso e gozo da propriedade e às atividades da comunidade.

Para CANÇADO et al (2006, p.5), a poluição atmosférica pode ser definida como a presença de substâncias estranhas na atmosfera, resultantes da atividade humana ou de processos naturais, em concentrações suficientes para interferir direta ou indiretamente na saúde, segurança e bem-estar dos seres vivos.

A poluição do ar ocorre quando a alteração da composição da atmosfera resulta em danos reais ou potenciais. Dentro deste conceito, pressupõe-se a existência de níveis de referência para diferenciar a atmosfera poluída da atmosfera não poluída. Sob o aspecto legal é denominado de qualidade do ar o nível de referência utilizado no Brasil (CETESB, 2011).

Ainda segundo a CETESB (2011), os padrões de qualidade do ar (PQAr), segundo publicação da Organização Mundial da Saúde (OMS) em 2005, variam de acordo com a abordagem adotada para balancear riscos à saúde, viabilidade técnica, considerações econômicas e vários outros fatores políticos e sociais, que por sua vez dependem, entre outras coisas, do nível de desenvolvimento e da capacidade nacional de gerenciar a qualidade do ar. As diretrizes recomendadas pela OMS levam em conta esta heterogeneidade e, em 
particular, reconhecem que, ao formularem políticas de qualidade do ar, os governos devem considerar cuidadosamente suas circunstâncias locais antes de adotarem os valores propostos como padrões nacionais.

De acordo com GUIMARÃES, citado por REIS, PINHEIRO e LIMA (2002, p.291), "a poluição do ar é o resultado da alteração das características físicas, químicas ou biológicas normais da atmosfera, de forma a causar danos ao ser humano, à fauna, à flora e aos materiais ou restringir o pleno uso da propriedade, afetar negativamente o bem-estar da população; ou seja, a poluição ocorre quando a alteração resulta em danos reais ou potenciais".

As fontes naturais de poluição do ar são a queima acidental de biomassa (qualquer derivado de plantas ou animais) e erupções vulcânicas, as quais podem ser consideradas as mais antigas fontes de contaminação do ar (CANÇADO et al, 2006, p.5).

Para os autores a queima de biomassa, em ambientes externos e internos, utilizada desde a pré-história para produção de energia, tem sido uma das importantes fontes antropogênicas de poluição atmosférica.

A partir da Revolução Industrial, surgiram novas fontes de poluição do ar devido à queima de combustíveis fósseis nos motores a combustão e nas indústrias siderúrgicas e, mais recentemente, nos veículos automotivos, além dos produtos químicos (CANÇADO et al, 2006, p.6).

No entanto, o problema da poluição atmosférica começou a ser sentido de forma acentuada quando as pessoas começaram a viver em assentamentos urbanos de grande densidade demográfica, com o crescimento acelerado da população mundial, indo de 1,5 bilhões de pessoas, no início do século $X X$, para seis bilhões de pessoas no fim desse mesmo século. Com relação às inovações tecnológicas, ocorridas principalmente nesse último período, merecem destaque 
como agentes poluidores os processos industriais, a metalúrgica e o automóvel (ASSUNÇÃO e MALHEIROS, 2009, p.136).

De acordo com SZWARC et al (2010, p.134), o transporte individual motorizado ganhou popularidade no mundo em função da liberdade de mobilidade e do status social que oferece. Esses valores são acentuados diariamente por uma avalanche de publicidade que vende o "sonho" do automóvel para todos os gostos e classes sociais. No Brasil, o recente ciclo de desenvolvimento econômico, que proporciona ascensão social e crescimento de renda, também tem estimulado a venda de veículos automotores.

Esse processo apoiado em disponibilidade de crédito e financiamentos de longo prazo aumentou as vendas de automóveis e comerciais leves (pic-ups) de 1,2 milhão de unidades em 1999 para três milhões em 2009, representando uma expansão de 150\% (cento e cinquenta por cento) no período.

Para as motocicletas e motonetas, a variação no mesmo período foi de 440 mil para 1,6 milhão, com um crescimento de $265 \%$ (duzentos e sessenta e cinco por cento). O resultado é evidente: houve uma invasão das ruas pelos carros e motos, com consequente aumento da emissão de poluentes e geração de ruído.

Destaca-se nesse processo a diversidade de atividades desenvolvidas por vários grupos sociais com mobilidade intensa e variada e que não têm em outras formas de transporte, as opções para fazer a conectividade entre destinos encadeados. Tudo isso por conta da baixa qualidade dos serviços de transporte por ônibus, com sua falta de pontualidade, lotação excessiva, períodos longos de espera, falta de conforto e insegurança em diversas rotas, especialmente nos horários noturnos; abrangência limitada dos serviços de metrô e trens e alto custo dos serviços de táxi (SZWARC et al, 2010, p.135). 
A elevada e crescente taxa de motorização para transporte individual estimula a baixa ocupação dos veículos; em média cada automóvel transporta 1,2 pessoas por viagem na Região Metropolitana de São Paulo (RMSP), ou seja, vai o motorista e, eventualmente, mais uma pessoa. Trata-se, evidentemente, de uma situação insustentável, energética e ambientalmente. 


\subsubsection{O Automóvel}

É interessante conhecermos um pouco do histórico e da evolução do automóvel no mundo e no Brasil.

O primeiro veículo autopropulsionado surgiu em 1769. Era um triciclo construído para fins militares, utilizando motor a vapor, e foi concebido pelo engenheiro francês Nicolas Joseph Cugnot (1725 - 1804). Foi construído no Arsenal de Paris pelo mecânico Brezin, sob a orientação de Cugnot e foi usado pelo exército francês para puxar canhões a uma velocidade de $4 \mathrm{~km} / \mathrm{h}$. $O$ veículo tinha de parar a cada 15 minutos para reabastecer o motor.

Tanto o motor como o depósito da água eram separados do resto do veículo, ficando na sua parte dianteira. No ano seguinte (1770), Cugnot construiu outro modelo de triciclo capaz de transportar quatro pessoas (http://www.sinaldetransito.com.br/curiosidade foto.php?IDcuriosidade $=38$ acessado em 10/10/2012).

Já o primeiro automóvel motorizado a ser produzido com o propósito comercial foi um carro com apenas três rodas, em 1885, pelo alemão Karl Benz e possuía um motor a gasolina. Posteriormente, foram surgindo outros modelos, vários deles com motores de dois tempos, inventado, no ano de 1884, por Gottlieb Daimbler.

Algum tempo depois, uma empresa francesa, chamada Panhard et Levassor, iniciou sua produção e venda de veículos. Em 1892, Henry Ford produziu seu primeiro carro na América do Norte.

Os ingleses demoraram um pouco mais em relação aos outros países europeus devido à lei da bandeira vermelha (1862). Esta impunha aos veículos transitar somente com uma pessoa em sua frente, segurando uma bandeira vermelha como sinal de aviso. O Lanchester foi o primeiro carro inglês, e, logo após vieram outros como: Subean, Swift, Humber, Riley, Singer, Lagonda, entre outros. 
No ano de 1904, surgiu o primeiro Rolls Royce com um radiador que não passaria por nenhuma transformação. A Europa seguiu com sua frota de carros: na França (De Dion Bouton, Berliet, Rapid), na Itália (Fiat, Alfa-Romeo), na Alemanha (Mercedez-Benz), já a Suiça e a Espanha partiram para uma linha mais potente e luxuosa: o Hispano-Suiza.

Após a Primeira Guerra Mundial, os fabricantes iniciaram uma linha de produção mais barata, os automóveis aqui seriam mais compactos e fabricados em séries. Tanto Henry Ford, nos Estados Unidos da América quanto Willian Morris na Inglaterra, produziram modelos como: o Ford, o Morris e o Austin. Estes tiveram uma saída impressionante das fábricas.

Com o resultado, logo outras fábricas começaram a produzir veículos da mesma forma, ou seja, em série. Este sistema de produção ficou conhecido como fordismo.

No caso do Brasil e também em outros países da América Latina, esta evolução automotora chegou somente após a Segunda Guerra Mundial. Já na década de 1930, fábricas estrangeiras, como a Ford e a General Motors, colocaram suas linhas de montagem no país. Porém, foi somente em 1956, durante o governo de Juscelino Kubitschek que as multinacionais automotivas começaram a montar realmente os automóveis.

Primeiramente fabricaram caminhões, camionetas, jipes, furgões e, finalmente, carros de passeio. Esta indústria foi iniciada pela Fábrica Nacional de Motores, que era responsável pela produção de caminhões pesados. Posteriormente vieram: automóvel JK com estilo Alfa-Romeo, Harvester, Mercedes-Benz do Brasil com seus caminhões e ônibus, a Scania-Vabis e a Toyota.

Logo depois, carros de passeio e camionetas começaram a ser produzidos: Volkswagem, DKW-Vemag, Willys-Overland, Simca, Galaxie, Corcel (da Ford), Opala (da Chevrolet), Esplanada, Regente 
e Dart (da Chrysler). Todos estes veículos, embora montados no Brasil, eram projetados nas matrizes européias e norte-americanas, utilizando a maioria de peças e equipamentos importados.

Diferente de antigamente, hoje o automóvel possui como características o conforto e a rapidez, além de ser bem mais silencioso e seguro. Nos últimos anos, os carros vêm passando por inúmeras mudanças, e estas, os tornaram cada vez mais cobiçados pelos consumidores. Todo o processo de fabricação gera milhões de empregos em todo mundo e movimenta bilhões de dólares, gerando lucros para as multinacionais que os fabricam.

Dessa forma aumentou o número de pessoas que possuem automóveis como podemos observar na figura 1.

Figura 1 - Trânsito causado pelos automóveis na cidade de São Paulo

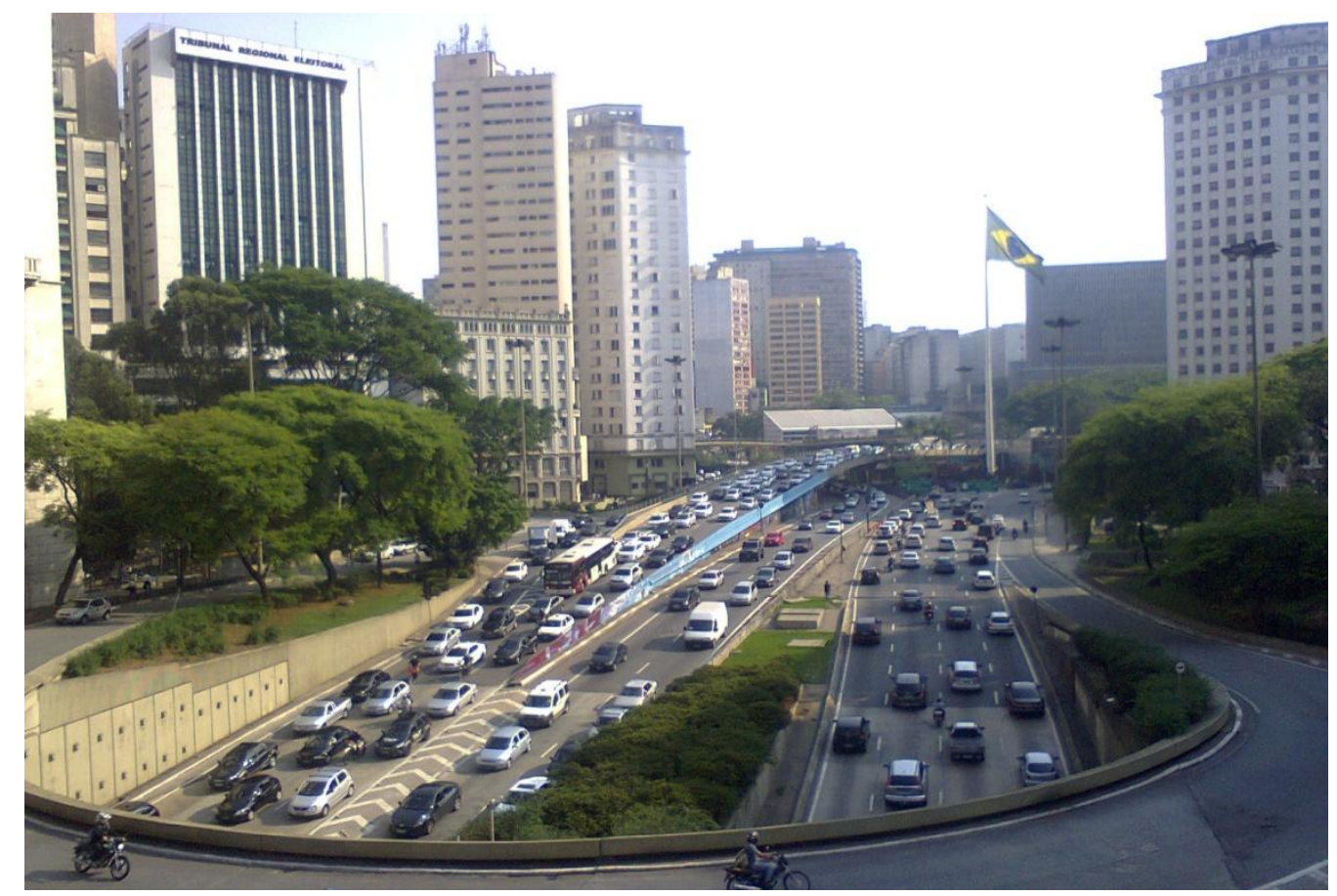

Foto: Oliveira, SC tirada em 2012 
SZWARC et al (2010, p.135-136), destacam que um dos principais problemas associados ao contínuo e intenso crescimento da frota de veículos automotores é a ocupação do espaço viário, cada vez mais escasso. Essa questão torna-se ainda mais crítica quando se observa uma tendência no aumento de vendas de veículos desnecessariamente grandes, como as peruas e jipes tipo SUV (Sport Utility Vehicles), que viraram moda e tornam o trânsito ainda mais problemático. Esses veículos foram originalmente desenvolvidos para o mercado norte-americano, onde as cidades dispõem de vias largas e apropriadas para a sua circulação, o que normalmente não ocorre nas grandes cidades brasileiras.

Enquanto um veículo compacto ocupa aproximadamente $12 \mathrm{~m} 2$ de espaço viário, uma perua SUV ocupa cerca de $17 \mathrm{~m} 2$, ou seja, $42 \%$ (quarenta e dois por cento) mais do que o veículo compacto, o que reduz o espaço de circulação nas já estreitas ruas da Região Metropolitana de São Paulo (RMSP) e contribui para a lentidão do trânsito.

É fato conhecido que os veículos automotores são a principal fonte de poluição atmosférica e de ruído em São Paulo como também, em outras regiões metropolitanas do país.

Para diminuir a severidade do problema e compatibilizar o uso do transporte motorizado com os padrões de qualidade do ar e de qualidade sonora vigente no país, o Conselho Nacional do Meio Ambiente (CONAMA) criou quatro programas importantes, destinados a reduzir a emissão de poluentes dos veículos e das motocicletas: o Programa de Controle da Poluição do Ar por Veículos Automotores (Proconve), o Programa de Controle da Poluição do $\operatorname{Ar}$ por Motociclos, Ciclomotores e Similares (Promot), o Programa Nacional de Controle de Ruído Veicular (PNCRV) e a Inspeção e Manutenção (IM). Foram desenvolvidos com base em experiências bem-sucedidas nos EUA, União Europeia e em outros países. 
Para BRANCO, SZWARC e BRANCO (2012, p.25), é necessário esclarecer que no caso dos três primeiros programas mencionados, os limites de emissão tem como objetivo primordial promover a adoção de tecnologias para reduzir a emissão em massa dos poluentes regulamentados monóxido de carbono (CO), hidrocarbonetos $(\mathrm{HC})$, óxidos de nitrogênio (NOx), material particulado (MP), aldeídos) e o ruído a determinados níveis máximos, enquanto, no caso da Inspeção e Manutenção (I/M), são apenas valores de referência para a aferição do estado de regulagem e manutenção do veículo e, portanto, meros padrões de verificação.

Segundo a Resolução CONAMA № 003 (1990, p 01), um poluente atmosférico é qualquer forma de matéria ou energia com intensidade e em quantidade, concentração, tempo ou características em desacordo com os níveis estabelecidos e que tornem ou possam tornar o ar:

- Impróprio, nocivo ou ofensivo à saúde;

- Inconveniente ao bem-estar público;

. Danoso aos materiais, à fauna e flora e

- Prejudicial à segurança, ao uso e gozo da propriedade e as atividades normais da comunidade.

A variedade de substâncias que podem estar presentes na atmosfera é muito grande. No entanto, em relação à sua origem, os poluentes podem ser classificados em:

Poluentes Primários - aqueles emitidos diretamente pelas fontes de emissão. Exemplos: Monóxido de Carbono (CO), Dióxido de Enxofre ( $\mathrm{SO}_{2}$ ) e Óxido Nítrico (NO).

A emissão destes poluentes para a atmosfera pode desencadear a formação de outros poluentes devido a determinadas 
reações com as variáveis metereológicas: radiação solar, temperatura e umidade.

Poluentes Secundários - aqueles formados na atmosfera através da reação química entre poluentes primários e/ou constituintes naturais na atmosfera. Exemplos: Ozónio $\left(\mathrm{O}_{3}\right)$ e Nitrato (NO3).

Quase toda massa da atmosfera, cerca de $90 \%$ (noventa por cento), localiza-se nos primeiros $30 \mathrm{~km}$ de altitude, sendo que $50 \%$ (cinquenta por cento) estão concentrados nos primeiros $5 \mathrm{~km}$.

A atmosfera é uma espessa camada de gases contendo líquidos em suspensão e partículas sólidas que envolvem completamente a Terra, e junto com esta formam um sistema ambiental integrado (KEMP, 1994).

Segundo KEMP (1994), a camada seguinte, a estratosfera, é mais seca e contém grandes quantidades de ozônio, tendo uma importância científica em função dos processos de absorção e dispersão dos raios solares que ali incidem.

Acima da estratosfera estão as regiões quimiosfera (mesosfera) e ionosfera (termosfera) que influenciam diretamente na quantidade e na distribuição espectral da energia solar e nos raios solares cósmicos que alcançam as camadas inferiores. 
Esta estrutura vertical da atmosfera, sua delimitação em várias camadas sobrepostas, está baseada no perfil de temperatura traçado na medida em que varia a altitude, conforme mostra a Figura 2, a seguir.

Figura 2 - A estrutura vertical da atmosfera

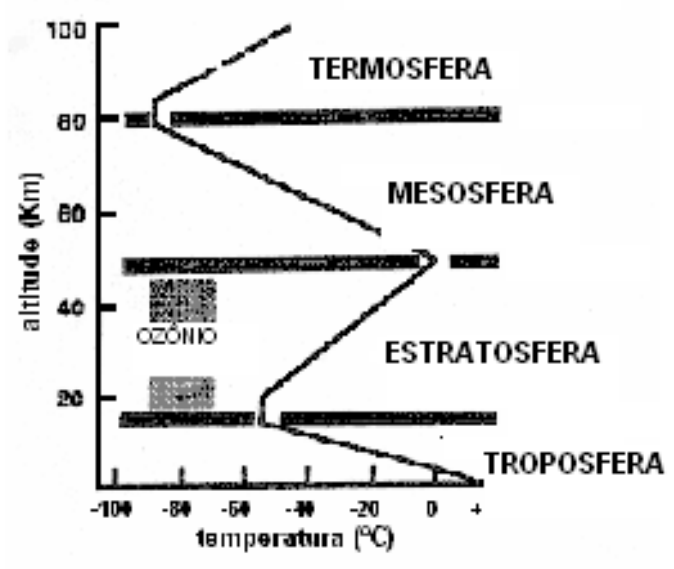

Extraído de: Kemp, 1994

O mesmo autor descreve que a região mais próxima à superfície da terra é chamada troposfera, sendo uma camada de ar estreita e densa que contém praticamente toda a massa gasosa da atmosfera isto é, $75 \%$ (setenta e cinco por cento), além de quase todo o vapor d'água e aerossóis. É a zona na qual ocorre a maioria dos fenômenos atmosféricos e onde a manifestação dos problemas ambientais globais - chuva ácida, turbidez atmosférica e aquecimento global - têm sua origem e alcança sua maior extensão, devido ao nível de intervenção humana a que está submetida. 


\section{- Chuva ácida}

A chuva ácida é o resultado da combinação do hidrogênio presente na atmosfera com alguns poluentes emitidos pela queima do carvão, pelo petróleo e pelas atividades industriais.

Os principais gases que a formam são o dióxido de enxofre ( $\mathrm{SO}_{2}$ ) e os óxidos de nitrogênio ( $\mathrm{NO} x$ ), que compõem o ácido sulfúrico $\left(\mathrm{H}_{2} \mathrm{SO}_{4}\right)$ e o ácido nítrico $\left(\mathrm{HNO}_{3}\right)$. O primeiro é proveniente sobretudo da queima dos combustíveis fósseis, que sempre contem enxofre e o segundo, dos processos industriais que envolvem altas temperaturas. A água da chuva, assim como a geada, a neve e a neblina, ao cair carregada desses ácidos, altera a composição química do solo e das águas, atinge as cadeias alimentares, destrói florestas e lavouras e ataca estruturas metálicas, monumentos e edificações (MENDONÇA et al 2010).

\section{- Turbidez atmosférica}

É a redução da transparência do ar resultante tanto da dispersão da luz por pequenas partículas no ar (gotículas de água, cristais de gelo, poeira e partículas de fumaça) como da absorção de luz por vapor de água.

Todos esses fatores fazem com que o ambiente em que vivemos, fique cada vez mais contaminado causando assim a poluição ambiental.

Poluição ambiental é a alteração desfavorável do meio causada pelos subprodutos e resíduos que resultam da atividade do homem e, às vezes, de fenômenos naturais. Essa alteração pode implicar em mudanças na transferência de energia, no nível de radiações, na composição física e química do meio e na abundância de certos organismos. As mudanças podem afetar o homem direta ou indiretamente, por intermédio da água, do ar, dos alimentos, ou ainda 
interferir nas suas oportunidades de recreação e apreciação da natureza (MENDONÇA et al 2010).

\subsection{As Mudanças Climáticas, O Aquecimento Global e a Saúde}

De acordo com o Sumário Revisado publicado pela OMS em (2008), as fotos produzidas pela Apollo em sua missão à lua em 1969 propiciaram cenas extraordinárias deste planeta, suspenso no espaço, transformando a forma como pensamos sobre a biosfera e seus limites. Nosso entendimento cada vez maior sobre a mudança climática está transformando nossa visão das fronteiras e os determinantes da saúde humana. Embora nossa saúde pessoal possa parecer estar relacionada primordialmente a um comportamento prudente, hereditariedade, ocupação, exposição ao meio ambiente local e acesso à assistência médica, a saúde sustentada da população requer os "serviços" vitais da biosfera. As populações de todas as espécies animais dependem de suprimentos de alimentos e água, de estar livres de excessos de doenças infecciosas e da segurança e do conforto.

A mesma publicação da OMS mostra que as atividades humanas estão alterando o clima no mundo. Estamos aumentando a concentração atmosférica de gases que retêm energia, amplificando, assim, o "efeito estufa" natural que torna a terra habitável. Esses gases de efeito estufa (GEE) compreendem principalmente, dióxido de carbono (em sua maioria proveniente da combustão de combustível fóssil e de incêndios florestais), além de outros gases que retêm calor, como, por exemplo, metano (resultante de agricultura irrigada, acasalamento de animais e extração de petróleo), óxido nitroso e vários halos carbonetos produzidos pelo homem. 
Segundo MENDONÇA et al $(2010$, p.114), a presença do carbono na atmosfera é essencial para garantir que a temperatura oscile dentro dos limites necessários para a existência da vida. $O$ carbono forma uma redoma protetora, que aprisiona parte das radiações vindas do sol e mantém a temperatura da superfície dentro de um gradiente ideal para os seres vivos.

Os autores relatam que sem o efeito estufa natural, isto é, sem - carbono na atmosfera, a superfície seria coberta de gelo. O excesso de carbono, no entanto, tende a elevar a temperatura atmosférica, originando um fenômeno conhecido como efeito estufa.

A escala global das mudanças climáticas difere fundamentalmente das muitas outras preocupações ambientais familiares com riscos toxicológicos ou microbiológicos localizados. De fato, mudanças climáticas significam que, hoje, estamos alterando os sistemas biofísicos e ecológicos da Terra na escala planetária - o que também é evidenciado pela destruição do ozônio estratosférico, que acelera perdas de biodiversidade pela pressão nos sistemas de produção de alimentos terrestres e marinhos, pela exaustão de fontes de água potável e pela disseminação global de poluentes orgânicos persistentes (OMS, 2008).

Para OLIVEIRA e ALVES (2011, p.31), as avaliações do Painel Intergovernamental sobre Mudanças Climáticas (IPCC) indicam que os países em desenvolvimento estão entre os mais vulneráveis às mudanças do clima. No caso do Estado de São Paulo, com uma economia similar à de países desenvolvidos, ao mesmo tempo em que vive a realidade desses países, compartilha das dificuldades de crédito, preço mínimo, seguro e escoamento da produção agropecuária dos países em desenvolvimento.

Até o final do século $X X$, conforme as análises compiladas pelo Painel Intergovernamental sobre Mudanças Climáticas (IPCC), a temperatura média atmosférica no Brasil aumentou aproximadamente, $0,75^{\circ} \mathrm{C}$ houve ainda nas temperaturas mínimas um aumento de até 
$1,4^{\circ} \mathrm{C}$ por década e uma variação entre 0,4 e $0,6^{\circ} \mathrm{C}$ nas temperaturas médias e máximas. Nos últimos 10 anos, no Estado de São Paulo, observou-se um aumento da temperatura mínima em maior número de locais. O mesmo ocorreu com as temperaturas máximas (MARENGO apud OLIVEIRA e ALVES, 2007).

O aumento da temperatura associado à mudança climática indica que no Estado de São Paulo, assim como no Brasil, sistemas físicos, biológicos e a sociedade serão afetados. O fato é que são vulneráveis aos impactos provocados pelas alterações climáticas.

Segundo TANAKA (2010, p.11), há cerca de 30 anos os cientistas vêm nos alertando sobre o aquecimento global. Mas muitos de nós começamos a captar a mensagem recentemente.

O planeta está ficando mais quente e o aquecimento é causado em parte pela atividade humana. $O$ aquecimento está acontecendo em ritmo veloz. A temperatura na superfície da Terra, que não mudou muito em 10 mil anos, está consideravelmente mais quente de 150 anos para cá. Se essa tendência se mantiver, muitas espécies, até mesmo a humana, não conseguirão se adaptar a tempo de evitar dificuldades (TANAKA, 2010, p.11).

Nos últimos 100 anos, a média global de temperatura aumentou pelo menos $0,8^{\circ} \mathrm{C}$, sendo que três quartos desse aumento ocorreram nos últimos 30 anos. E nos $100 \mathrm{mil}$ anos em que os seres humanos estão por aqui, o planeta nunca esteve mais que um ou dois graus mais quente do que hoje.

O hemisfério norte está esquentando de modo mais intenso que o hemisfério sul.

Em 2002, a leste da península Antártica, uma gigantesca massa de gelo flutuante, com área maior que o estado de Alagoas, quebrou e se separou do continente, desintegrando-se em apenas 35 dias. A camada de gelo da Groenlândia, com mais de três quilômetros de espessura e pouco menor que o México, começou a derreter de 
repente e está escorrendo para o oceano muito mais rapidamente do que os cientistas previram.

Se o aquecimento continuar como se espera, por volta de 2050, pela primeira vez em dois milhões de anos, a Islândia não terá geleiras, os ursos-polares se extinguirão e as geleiras do Himalaia, que abastecem de água 500 milhões de pessoas, desaparecerão.

O clima seco e quente na China está provocando intensas tempestades de areia, que sopram a poeira através do Pacífico e poluem o ar na costa oeste da América do Norte. Enquanto isso, a camada mais superficial de todos os mares do mundo está esquentando e se expandindo devido ao aumento dos gases do efeito estufa produzidos pelos seres humanos (TANAKA, 2010, p.14).

Dos anos 1960 para cá, observa-se que a temperatura está aumentando rapidamente, cada ano faz mais calor - um aquecimento acelerado e expandido como não se via há pelo menos 1.200 anos.

Mudanças climáticas que normalmente levavam milhares de anos para se completar agora ocorrem em apenas algumas décadas.

Como o ser humano pôde mudar o clima do planeta?

De muitas maneiras, mas a mais importante é que de 150 anos para cá, desde que o mundo se tornou industrializado, as pessoas queimam quantidades cada vez maiores de combustíveis fósseis contendo carbono, carvão, petróleo e gás natural, que liberam dióxido de carbono $\left(\mathrm{CO}_{2}\right)$ na atmosfera. O dióxido de carbono retém o calor da Terra e faz com que as temperaturas atmosféricas aumentem.

Atualmente, há 20\% (vinte por cento) mais dióxido de carbono na atmosfera do que 250 anos atrás. A liberação atmosférica desse carbono ocorre toda vez que o ser humano queima combustível fóssil para aquecer sua casa, produzir eletricidade ou dirigir seu carro.

Assim, TANAKA conclui que: "o problema das mudanças climáticas é difícil de ser enfrentado, porque não se limita à 
compreensão da ciência, o consenso científico é claro, mas o aquecimento global envolve questões de ordem econômica, política, filosófica e emocional" (2010, p.24).

Os efeitos da poluição atmosférica são diversos e apresentam diferentes graus de risco, estendendo-se dos toxicológicos ao econômico.

Além dos seres humanos, outros animais, materiais e plantas, podem ser afetados pelos efeitos de poluentes do ar.

No período de inverno, estação em que pouco venta e quase não chove, ocorre com mais frequência o fenômeno da inversão térmica, o que agrava a situação. O nível de sujeira no ar ultrapassa os limites considerados suportáveis para a saúde da população.

A inversão térmica acontece quando uma camada de ar frio se sobrepõe a uma camada de ar quente e impede o movimento ascendente do ar. Em situações normais, o ar quente sobe e o ar frio desce. Na inversão térmica, o ar quente sobe durante o dia, mas, à noite, a superfície sofre um resfriamento rápido, formando uma camada de ar frio abaixo da camada de ar quente. $\mathrm{A}$ camada de ar frio, mais densa e pesada, terá dificuldade para subir e permanecerá próxima à superfície.

Nas grandes cidades, onde há alta atividade industrial e numerosa frota de veículo, a camada de ar frio começa a concentrar os poluentes: a fumaça fica presa e se acumula com o passar dos dias. É raro ocorrer inversão térmica nos dias quentes, pois o sol, ao aquecer a superfície, aquece o ar, que sobe, carregando os poluentes. No inverno, o clima fica propício para as inversões térmicas, pelo rápido resfriamento da superfície (MENDONÇA et al, 2010, p.114). 
Em entrevista concedida ao JORNAL DIÁRIO DO COMÉRCIO datado de 02/08/2011, p 11, o patologista Paulo Hilário Nascimento Saldiva, ressaltou que a "emissão dos mais variados poluentes somados à pouca dispersão dos gases tóxicos no inverno acabou resultando em problemas de saúde bem conhecidos do paulistano: as moléstias do aparelho respiratório".

SALDIVA ainda citou que em 2010, o número de pessoas que moram na cidade superou o daqueles que vivem no interior. "(...) no entanto, essa concentração resultou em problemas, muitos deles ambientais. Consumimos muita energia, produzimos nosso ambiente e isso, é um problema para o homem urbano (...) é preciso discutir a saúde e o meio ambiente com mais profundidade. 


\subsection{Agravos à Saúde pela poluição do ar}

Cada vez mais a mídia vem noticiando em jornais, revistas e pela TV os problemas provocados pela poluição do ar com destaque para os agravos à saúde da população.

O aumento da frequência desse tipo de agravo é a ponta de um iceberg, pois nessas circunstâncias, entende-se que praticamente toda a população está de certa forma sofrendo sob a atmosfera envenenada e, sem dúvida, mesmo que subclinicamente é vítima do impacto relativo ao problema ambiental (NATAL, 2004, p.341).

Nos últimos anos muitos estudos encontraram associação entre as concentrações de poluentes atmosféricos e os efeitos à saúde das pessoas no município de São Paulo, a partir de dados de mortalidade, internação hospitalar e atendimentos ambulatoriais por doenças respiratórias e cardiovasculares em crianças e idosos e, ainda, de mortalidade intrauterina (TOLEDO, 2010, p.23).

Esses efeitos podem ser: a) Biológicos - efeitos prejudiciais à saúde humana, dos animais e sobre as plantas; b) Físicos - redução da visibilidade, sujidade, aquecimento do planeta, entre outros; e c) Químicos - corrosão e deterioração de materiais, incluindo objetos culturalmente importantes como estátuas e monumentos, erosão de superfícies, entre outros.

Segundo CANÇADO et al (2006, p.7), a poluição do ar causa uma resposta inflamatória no aparelho respiratório induzida pela ação de substâncias oxidantes, as quais acarretam aumento da produção da acidez, da viscocidade e da consistência do muco produzido pelas vias aéreas, levando, consequentemente, à diminuição da resposta e/ou eficácia do sistema mucociliar.

SALDIVA et al., 1994, citado por SANT'ANNA (1996), demonstraram uma associação significativa entre mortalidade infantil por doenças respiratórias, na faixa etária inferior a cinco anos e os níveis de poluição urbana. A associação permaneceu válida, mesmo com o controle das diversas 
variáveis tais como, efeito climático, variação sazonal da mortalidade e mortes por causas não respiratórias. Os óxidos de nitrogênio foram os poluentes mais fortemente associados com a mortalidade infantil.

De acordo com MARTINS et al (2002, p. 89), as crianças e os idosos são os dois grupos etários que têm se mostrado mais susceptíveis aos efeitos da poluição atmosférica.

Para esses autores muitos estudos têm indicado uma associação positiva entre mortalidade e morbidade por problemas respiratórios em crianças. Já entre os idosos, a poluição atmosférica tem sido associada a aumentos de morbidade (internações) e de mortalidade, tanto por doenças respiratórias quanto por doenças cardiovasculares.

Os autores seguem dizendo que: internações ou mortalidade por problemas respiratórios poderiam refletir os efeitos mais graves da poluição. Dessa forma, afirmam que é importante avaliar se a poluição do ar poderia afetar a saúde dos idosos em eventos mais agudos provocando aumento da demanda dos atendimentos em pronto-socorro.

Nos países em desenvolvimento, aproximadamente 0,5 a 1 milhão de pessoas morrem anualmente, como consequência da exposição à poluição atmosférica nas áreas urbanas, além dos milhões de casos de doenças respiratórias, associadas também a esse problema. Dessa forma é necessário o empreendimento de ações de todos os setores da sociedade, de modo a reverter esse quadro que, em última análise, resulta em impactos econômicos às nações, ao bem-estar das comunidades e ao meio ambiente (KAJIMA e LOVEI, 2001, citado por PHILIPPI JR e MALHEIROS 2005, p.439-41).

Segundo os mesmo autores para este enfrentamento é preciso o estabelecimento de políticas que priorizem ações integradas na reversão dessa problemática; o desenvolvimento de programas de educação ambiental formal e não formal; a minimização da produção de resíduos, por meio da mudança nos padrões de consumo e de produção, entre outros. 
Para SANT ANNA (1996) os efeitos adversos da poluição sobre a saúde foram melhor evidenciados em períodos ditos "episódicos" de contaminação atmosférica, ou seja, quando havia a conjunção de níveis elevados de poluição, com uma população exposta em número significativo, manifestando sofrer algum tipo de dano.

Episódios agudos de poluição do ar caracterizam-se pela pequena duração, de minutos a alguns dias e por provocar problemas graves. Muitos desses episódios ocorreram como resultado da permanência de condições desfavoráveis à dispersão dos poluentes por vários dias, como inversão térmica, ausência de chuvas, ventos calmos, aliados à emissão contínua de poluentes e topografia desfavorável, um vale, por exemplo, (SANT`ANNA, 1996).

Entre esses eventos destaca-se o de Londres, Inglaterra em dezembro de 1952, com duração de cinco dias, que resultou em cerca de quatro mil mortes, principalmente na faixa etária dos idosos. Esse incidente ocorreu em razão da presença de altas concentrações de fumaça (smoke) e dióxido de enxofre na atmosfera, e também por causa de condições metereológicas desfavoráveis, tais como inversão térmica, calmaria e neblina (fog). Ocorreram ainda outros episódios agudos em Londres, ocasionando a morte de centenas de pessoas. Em 1957, morreram oitocentas e, em 1962, setecentas pessoas foram a óbito (GUIMARÃES, 1992, p. 291).

Na década de 1920, nos Estados Unidos, o serviço público de saúde realizou medições da concentração de particulados em sete grandes cidades. Foram observados valores de até 3.600 miligramas por metro cúbico. O valor médio anual hoje admitido é de 75 miligramas por metro cúbico (GUIMARÃES, 1992, p. 291).

Em 1948, os Estados Unidos tiveram vinte mortes e 1440 casos de pessoas afetadas por névoa poluída, sem dissipação. Em 1952, em um período de altíssima concentração de dióxido de enxofre ( $\left.\mathrm{SO}_{2}\right)$, Nova York contabilizou a morte de 168 pessoas devido à alta concentração do SO2. Na Índia, em 1984, o vazamento de uma fábrica de pesticidas provocou a morte de 2500 pessoas. 
Não podemos esquecer o acidente nuclear que aconteceu no mundo em Chernobyl, na Ucrânia, em 1986, onde o material radioativo que escapou foi levado pelos ventos e se espalhou pela Europa (GUERRA et al, 2006, p. 26).

Entre tantos episódios que causaram problemas ambientais, destaca-se nos dias de hoje a queima dos poços de petróleo da Guerra do Golfo, no Iraque em 1991, onde a fumaça proveniente dos incêndios poluiu a neve no Himalaia, a $3000 \mathrm{~km}$ ao leste; além da erupção do monte Etna em 2002 em que o vento carregou fumaça e cinzas ao longo de centenas de quilômetros, por todo o leste do Mediterrâneo e também os incêndios florestais em Portugal no ano de 2005 (GUERRA et al, 2006).

Outro evento ambiental importante foi o acidente nuclear de Fukushima no Japão ocorrido em 2011, onde a liberação de radiação contaminou uma área chamada de "zona morta", que reúne centenas de quilômetros quadrados ao redor da planta atômica.

De acordo com GREENPEACE a qualidade do ar em Pequim, China no dia 13 de Janeiro de 2013 foi a pior já registrada tendo a poluição chegado de 30 a 45 vezes acima dos níveis de segurança recomendados pela Organização Mundial da Saúde (OMS). As partículas com menos de 2,5 micrômetros de diâmetro chegaram a mais de 600 microgramas por metro quadrado e no dia seguinte foram a 900 em algumas estações de monitoramento da cidade.

Segundo GOUVEIA et al (2003, p. 30) esses e outros episódios menos famosos foram suficientes para que se instituíssem medidas visando controlar os níveis ambientais de poluição do ar em diversos centros urbanos, principalmente em países da América do Norte e Europa. Dessa forma, por um longo período, não se observaram mais os efeitos da poluição do ar na saúde.

No Brasil, em particular no Estado de São Paulo, a preocupação com os acidentes de grande porte ganhou ênfase em 1984, após o rompimento de um duto de gasolina seguido de incêndio em Cubatão, fazendo cerca de 500 vítimas, das quais 93 fatais. Em função disso, parte do grupo de técnicos da CETESB que atuava no setor de atendimento corretivo relacionado a acidentes 
com produtos químicos, demonstrou interesse pela questão preventiva, dando início em 1985 às pesquisas sobre o tema (CETESB, 2012).

Percebe-se então claramente que a poluição do ar não é um fato isolado, mas um problema que atinge o mundo todo de diversas formas e tem causado muitos agravos à saúde da população.

Para ASSUNÇÃO (2009), esses agravos podem ir do desconforto até a morte, passando pelo aumento da taxa de morbidade (doenças); aumento de procura ao Sistema de Saúde (Centro de Saúde, Hospitais, Prontos-socorros); maior número de absenteísmo no trabalho; além de sintomas, tais como: irritação dos olhos e das vias respiratórias; redução da capacidade da atenção; dor de cabeça, alterações motoras e alterações enzimáticas, doenças do aparelho respiratório (asma, bronquite, enfisema, edema pulmonar, pneumoconiose), danos ao sistema nervoso central, efeitos teratogênicos, alterações genéticas e câncer. Mais recentemente, têm sido realizados também muitos estudos sobre a associação da poluição do ar com a mortalidade intrauterina, com as doenças cardiovasculares, perturbação da visão, diminuição dos reflexos, abortos e até mesmo com a síndrome de morte súbita infantil.

"A exposição prolongada a esse tipo de ambiente, situação cada vez mais frequente pelos congestionamentos da cidade, nos expõe a um risco que não podemos evitar e no caso das partículas finas, a exposição a altas quantidades, ainda que por curtos períodos, é suficiente para desencadear muitos problemas de saúde" (ASSUNÇÃO, 2009).

Pesquisas realizadas pela equipe de SALDIVA nos anos 2000 e 2001, no Laboratório de Poluição Atmosférica Experimental da Universidade de São Paulo (LPAE) mostraram claramente que: após submeterem 48 trabalhadores de trânsito (marronzinhos) saudáveis a exames, duas horas de trabalho em avenidas de grande fluxo foram suficientes para aumentar a pressão arterial do grupo estudado.

Os veículos são as principais fontes de partículas finas - responsáveis por $37 \%$ (trinta e sete por cento) do total. Caminhões e ônibus movidos a diesel poluem seis vezes mais que motos e carros (LPAE, 2007). 
Segundo CANÇADO et al (2006, p.6), o material particulado é uma mistura de partículas líquidas e sólidas em suspensão no ar. Sua composição e tamanho dependem das fontes de emissão. As partículas podem ser divididas em dois grupos: partículas grandes (coarse mode), com diâmetro entre 2,5 e $30 \mu$, emitidas através de combustões descontroladas, dispersão mecânica do solo ou outros materiais da crosta terrestre (poléns, esporos e materiais biológicos também se encontram nesta faixa de tamanho); e partículas


de fontes móveis e estacionárias, como automóveis, incineradores e termoelétricas, que por serem de menor tamanho e mais ácidas, podem atingir as porções mais inferiores do trato respiratório.

É oportuno salientar que a determinação da Agência de Proteção Ambiental Americana para controle de partículas menores ou iguais a $10 \mu$ (PM10), também chamadas de partículas inaláveis, se baseou no fato de que estas são as partículas que podem atingir as vias respiratórias inferiores e na sua composição química. Este material particulado inalável apresenta a importante característica de transportar gases absorvidos em sua superfície, até as porções mais distais das vias aéreas, onde ocorrem as trocas de gases no pulmão.

Os autores seguem dizendo que um estudo realizado com monitores pessoais para Material Particulado (PM) e monitores colocados dos lados externos e interno das residências mapeou a composição do Material Particulado domiciliar. Aproximadamente $50 \%$ do Material Particulado no interior das casas é proveniente do ambiente externo. $O$ restante tem origem na combustão de tabaco, no fogão a gás ou indeterminada.

A medida que vão se depositando no trato respiratório, essas partículas passam a ser removidas pelos mecanismos de defesa. O primeiro deles é o espirro, desencadeado por grandes partículas que, devido ao seu tamanho, não conseguem ir além das narinas, onde acabam se depositando. Outros importantes mecanismos de defesa são a tosse e o aparelho mucociliar. 
Aquelas partículas que atingem as porções mais distais das vias aéreas são fagocitadas pelos macrófagos alveolares, sendo então removidas via aparelho mucociliar ou sistema linfático (CANÇADO et al 2006, p.7). 


\subsection{A Poluição do ar e os veículos automotores}

Atualmente, o problema que precisa ser enfrentando é principalmente 0 da poluição causada por veículos automotores, visível em parte nas estradas e em parte nas cidades, sob a forma de fumaça preta saindo dos canos de escapamento. Existe ainda uma parcela invisível: trata-se da mistura de gases sem cor que os veículos movidos a álcool e à gasolina lançam diariamente sobre São Paulo. São gases tóxicos que envenenam o ar. E como o número de carros nas ruas cresce diariamente, cresce também a poluição do ar (ASSUNÇÃO e MALHEIROS, 2009).

O uso intensivo do petróleo nas indústrias de carvão, nas termoelétricas e no transporte automotivo, o qual se constitui, atualmente, na grande fonte móvel de poluição atmosférica dos centros urbanos, contribui para o aumento dos riscos para a saúde da população e para o meio ambiente em geral (REIS, PINHEIRO, LIMA, 2002, p.291).

Os autores afirmam que a decisão do ser humano de viver, cada vez mais, nos centros urbanos aumenta a quantidade de resíduos neles lançados, gerando níveis cada vez maiores de poluição do ar.

De acordo com a SECRETARIA ESTADUAL DE MEIO AMBIENTE DE SÃO PAULO (1997) as principais fontes de poluição do ar nas regiões urbanas são os veículos automotores, complementados pelo processo industrial de geração de calor, queima de resíduos, movimentação e estocagem de combustíveis.

O automóvel hoje é um dos meios de transporte mais utilizados para o deslocamento de pessoas, devido às facilidades de acesso para sua aquisição.

Segundo REZENDE e SOUZA (2009, p.3), essa preferência pelo transporte individual aumenta de maneira significativa o número de veículos nas ruas com o mínimo de aproveitamento do espaço disponível, tendo em vista que a maioria deles é conduzido pelo motorista que vai só, repetindo diariamente $\circ$ mesmo trajeto para 0 trabalho, para as escolas, para a 
universidade, entre outros. Respirar na cidade, torna-se pois um risco constante.

De acordo com dados do Instituto de Pesquisa Econômica Aplicada (IPEA, 1998) citado por REZENDE e SOUZA (2009) a utilização do automóvel para o indivíduo traz inúmeros benefícios, mas os governantes precisam incluir na quantificação dos custos os impactos decorrentes da sua utilização massiva para a sociedade.

As políticas para o transporte público incluem noções de solidariedade, integração e inclusão, além de reduzirem consideravelmente os custos urbanos.

CINTRA (2008) citado por REZENDE e SOUZA (2009, p. 4), alerta para o valor econômico das horas de trabalho desperdiçadas e a perda de qualidade de vida das pessoas, causada por estresse, esgotamento físico e danos psicológicos em decorrência do trânsito parado.

Os problemas causados pelo congestionamento por excesso de veículos nas ruas dos centros urbanos causam custos financeiros isto é, o preço do tempo perdido na viagem, o custo adicional de combustível, manutenção e depreciação dos veículos e o custo da poluição sonora e atmosférica (REZENDE e SOUZA, 2009).

Esses últimos embora sejam extremamente importantes quase nunca são avaliados. 


\subsection{A Promoção da Saúde}

Desde a década de 1970, objetivando a obtenção de um nível melhor de saúde para todos, diferentes ações para a promoção da saúde e para a preservação de doenças têm sido desenvolvidas, em diversos países.

A insatisfação gerada internacionalmente pelas condições de vida e saúde da maior parte da população mundial; a ênfase no modelo biomédico e suas consequências para a prevenção e o tratamento das doenças concepção mecanicista, reducionista e cartesiana da vida, que considerava apenas as explicações científicas, a etiologia das doenças, os diagnósticos clínicos e os prognósticos, não atendendo, portanto, às necessidades reais da população, deram origem, depois de muitas reflexões e discussões, em meados da década de 1970, à introdução de um novo conceito de Campo da Saúde proposto pelos canadenses (PELICIONI, 2000, p.2).

A autora diz ainda que de acordo com esse conceito, todas as causas de doenças e mortes decorrem de quatro fatores determinantes e interligados: as características biofísicas do indivíduo; o estilo de vida ou os fatores comportamentais; a poluição e os agravos ambientais; bem como a inadequação ou incompetência dos serviços de saúde, exigindo, portanto, soluções integradas (Lalonde, 1996 apud PELICIONI, 2000).

Dessas ideias surgiu uma nova concepção de saúde que vê o homem como parte do ambiente e não fora dele, que permitiu e percebeu-se a necessidade de realizar mudanças urgentes no ambiente, no qual o homem encontra-se inserido, bem como no seu comportamento, visando segundo PELICIONI, a promoção da saúde física e mental dos indivíduos, e considerando sua realidade socioeconômica e cultural (2000).

Em 1986 em Ottawa, Canadá, ocorreu a I Conferência Internacional de Promoção da Saúde, onde os profissionais ali reunidos aprovaram a Carta de Ottawa. Considerada um importante documento, veio contribuir, fundamentalmente, para o marco conceitual da Promoção da Saúde, como 
paradigma válido e alternativo aos problemas de saúde da população e ao seu sistema de atenção.

A partir daí, a Promoção da Saúde foi vista como o processo de capacitação da comunidade para atuar na melhoria da sua qualidade de vida e saúde, incluindo uma maior participação no controle deste processo sugerindo que para atingir um estado de completo bem-estar físico, mental e social, os indivíduos e grupos deveriam saber identificar aspirações, satisfazer necessidades e modificar favoravelmente o meio ambiente (CARTA DE OTTAWA, 1986).

Segundo CHIESA et al (2009, p.1), o campo da Promoção da Saúde tem sido descrito como um novo e promissor paradigma na saúde, dada a amplitude de suas abordagens teórico-metodológicas, configurando sua complexidade e suas principais bases conceituais, a saber: a ênfase na integralidade do cuidado e na prevenção de agravos à saúde; o compromisso social com a qualidade de vida; e a adoção da participação como planejamento e avaliação dos processos. Com tais bases, a Promoção da Saúde dá suporte à reorganização do trabalho em saúde, para que este se constitua como uma forma de resposta social organizada aos problemas e necessidades de saúde de uma dada população.

Na III Conferência Internacional de Promoção da Saúde realizada em 1991, em Sunsdwall, Suécia, concluiu-se que saúde, ambiente e desenvolvimento humano não poderiam ser tratados separadamente, pois desenvolvimento implica na melhoria da qualidade de vida e saúde, assim como na preservação e sustentabilidade do meio.

Posteriormente, a IV Conferência foi em Jacarta em 1998; a V no México em 2000, a VI em Bangkok em 2005 e a última, até o presente, foi em Nairobi, em 2009.

No Brasil em 2006, foi promulgada a Política Nacional de Promoção da Saúde que apresentou entre seus objetivos: "promover a qualidade de vida, reduzir a vulnerabilidade e riscos à saúde, bem como melhorar as condições de 
trabalho, habitação, ambiente, educação, lazer, cultura, acesso a bens e serviços essenciais" (BRASIL, 2006, p.13).

Melhorar a qualidade de vida da população tem sido um dos maiores desafios da humanidade neste século. As diferenças sociais e econômicas entre os países têm dificultado o encaminhamento de soluções para as questões relacionadas a um desenvolvimento justo e ambientalmente sustentável. Sabendo que o ambiente é um determinante social da saúde e da doença novos paradigmas, principalmente nas áreas de Saúde e Meio Ambiente, vêm surgindo a fim de contribuir para a transformação da sociedade por meio de uma distribuição equitativa dos recursos existentes, mantendo a diversidade ecológica, biológica e cultural dos povos (PELICIONI, 2000, p. 01).

Com a velocidade que o mundo evolui parece não ser possível perceber os novos avanços alcançados nessas áreas.

Em se tratando de saúde muitas pesquisas têm contribuído para evitar ou controlar doenças como (alguns tipos de câncer, diabetes entre outras) algumas dessas causadas por problemas ambientais.

Não podemos esquecer a invenção dos conversores catalíticos ou catalizador como é conhecido que contribuiu muito para minimizar os efeitos dos poluentes emitidos pelos veículos automotores que são os responsáveis por algumas doenças respiratórias.

Os conversores catalíticos, que começaram a ser utilizados nos Estados Unidos em 1975, possibilitam o tratamento dos gases de escape do motor, existindo atualmente dois tipos principais: o conversor catalítico oxidante, que oxida os hidrocarbonetos $(\mathrm{HC})$ e monóxido de carbono $(\mathrm{CO})$ a $\left(\mathrm{CO}_{2}\right)$ e $\left(\mathrm{H}_{2} \mathrm{O}\right)$ e não atuam sobre as emissões de (NOx) e o conversor catalítico de três vias, que oxida os hidrocarbonetos e monóxido de carbono a $\left(\mathrm{CO}_{2}\right)$ e $\left(\mathrm{H}_{2} \mathrm{O}\right)$ e reduz os óxidos de nitrogênio a $\left(\mathrm{N}_{2}\right)$. A utilização dos catalizadores, em conjunto com outras tecnologias, como a injeção eletrônica, permitiu reduzir significamente a emissão destes poluentes citados, contribuindo, portanto, na redução dos riscos da poluição veicular em áreas urbanas (PHILIPPI JR e MALHEIROS, 2005, p479-480). 
Isso foi um grande avanço tecnologico tendo em vista que esses veículos atualmente adquiridos deixaram de ser apenas um meio de deslocamento para a população e se tranformaram em objeto de desejo para parte daqueles que $o$ adquirem.

Segundo GULLO (1998, p.9), dentre os símbolos sociais mais importantes na sociedade contemporânea (imóveis, roupas, eletroeletrônicos), o veículo de transporte (carros, motos, embarcações, aeronaves) desempenha um papel fundamental no imaginário coletivo porque se transformou num referencial poderoso para a orientação do comportamento. A representação do seu significado social é mais forte e definidora do comportamento do que o seu valor intrínseco. Além de meio de transporte, é emoção, poder, prestígio, satisfação do desejo, respeito, conquista, sucesso, felicidade enfim. Não é o que ele oferece objetivamente que mais importa, mas o que ele representa no imaginário coletivo que o torna tão atraente, um ser supremo e superior como um deus ex machina que o indivíduo venera e se submete, na esperança de através dele atingir a felicidade ideal. Através do veículo podem ser satisfeitos os desejos de liberdade, de usufruto da velocidade, da conquista do prazer prometido, da descoberta da sensualidade, do devaneio, do erotismo, do deleite na sua plenitude, representando a obtenção do sucesso e 0 conhecimento da felicidade.

Ainda para o autor, numa sociedade de classes sociais, que considera o status social ou posição determinada ou definida por critérios ou atributos sociais como fundamental para o reconhecimento do lugar em que indivíduos ou grupos se situam na hierarquia social, a associação do veículo ao status lhe confere importância fundamental (SPARTI, 2003, p.40).

Como podemos perceber os efeitos da poluição do ar se caracterizam tanto pela alteração de condições consideradas normais como pelo aumento de problemas já existentes. Eles ocorrem em nível local, regional e global.

Se multiplicarmos os deslocamentos diários de cada pessoa, pelo número de habitantes de uma cidade, teremos milhares de deslocamentos em um único dia. Para esse conjunto de deslocamentos que caracterizam a circulação humana damos o nome de trânsito. 
Segundo VASCONCELOS (1998), o trânsito é, assim, o conjunto de todos os deslocamentos diários, feitos pelas calçadas e vias da cidade, e que aparece na rua na forma da movimentação geral de pedestres e veículos. Por isso, o trânsito não é apenas um problema 'técnico", mas sobretudo uma questão social e política, diretamente ligada às características da nossa sociedade.

O autor segue dizendo que se olharmos mais detalhadamente a circulação urbana, podemos ver que ela apresenta alguns conflitos que lhe são inerentes: o primeiro deles é o conflito físico, mais conhecido, de disputa pelo espaço, como no caso de dois veículos que se aproximam ao mesmo tempo de um cruzamento, ou de um pedestre que deseja passar entre vários veículos em movimento. Esse tipo de conflito é o mais aparente no trânsito mas não é o único: existe outro, chamado político, pois reflete os interesses das pessoas no trânsito, que por sua vez estão ligadas à sua posição no processo produtivo da sociedade.

Tudo isso nos faz assistir uma cena que virou rotina atualmente. Milhões de veículos novos passam a circular todos os dias nas metrópoles mundiais.

Segundo CHRISTIANINI E HAGIWARA (2008), a cada dia, uma média de 500 carros novos chegam às ruas paulistanas, sendo que em fevereiro de 2008 a frota de veículos da cidade atingiu o patamar histórico de 6 milhões de veículos. Este número correspondia a 14\% (quatorze por cento) da frota nacional e à mesma quantidade de veículos que circulavam em toda a Argentina.

Como consequência do modo como são projetados e construídos, dependendo do combustível que utilizam, e até da maneira como são mantidos e dirigidos ou, ainda, em virtude de sua quantidade, os veículos automotores por sua vez, tornaram-se e continuam sendo a maior fonte de poluição do ar também aqui na Região Metropolitana de São Paulo (RMSP). De fato, diariamente, uma frota de aproximadamente três milhões de veículos, lança na atmosfera toneladas de gases, vapores e material particulado, poluentes que comprometem a qualidade do ar que respiramos. 
Segundo MOTA, 1999, citado por BRUNA e PIRRÓ (2004, p.383-386) na Região Metropolitana de São Paulo, a maior parte da poluição do ar é devida aos transportes, que são responsáveis por cerca de 90\% (noventa por cento) da produção de monóxido de carbono, por uma alta proporção variando entre $70 \%$ (setenta por cento) e $90 \%$ (noventa por cento) dos hidrocarbonetos presentes na atmosfera e por aproximadamente entre $20 \%$ (vinte por cento) e $30 \%$ (trinta por cento) da presença de óxido de nitrogênio e ainda oxidantes fotoquímicos.

O autor refere que essa poluição do ar pode ser perigosa não só com a formação de nevoeiros que se colocam próximos às áreas urbanas, mas por sua transmissão via chuvas ácidas que acabam inutilizando o solo e a água para consumo, e também danificando a saúde. A emissão de poluentes produzidos pelos veículos ocorre tanto pelo escapamento, como pelo protetor de cárter, juntas e conexões do sistema de abastecimento de combustível, e pelos freios e pneus.

Pode-se lembrar, neste caso, que os pneus são responsáveis pela emissão de partículas em suspensão no ar, com todos os agravamentos que provocam a saúde da população. Costumam também contribuir para o efeito conhecido como ilhas de calor ou domos de poeira que são resultado da concentração de poluição e material particulado e que se expandem na atmosfera, a partir do centro urbano para as áreas mais periféricas. Essas massas de calor ao se resfriarem costumam precipitar-se na forma de chuvas ácidas (BRUNA e PIRRÓ, 2004, p.389).

Dados da Prefeitura Municipal de São Paulo (2007) no que se refere à emissão de Gás Efeito Estufa (GEE) mostram que o transporte rodoviário no município de São Paulo pode ser caracterizado a partir dos combustíveis utilizados: álcool, gasolina, gás natural veicular e óleo diesel. 
A gasolina é utilizada pelos automóveis e ciclomotores no transporte individual; o gás natural é usado principalmente nos veículos leves de passageiros, e o óleo diesel é usado nos veículos pesados como ônibus e caminhões, conforme apresentado no Quadro I, a seguir:

Quadro I - Distribuição de combustíveis utilizados na cidade de São Paulo, em 2007.

\begin{tabular}{|l|c|}
\hline \multicolumn{1}{|c|}{ TIPOS } & 2007 \\
\hline Álcool (automóveis camionetas e caminhões) & 686.049 litros \\
\hline $\begin{array}{l}\text { Gasolina (motos, automóveis, camionetas e } \\
\text { caminhões) }\end{array}$ & 4.185 .435 litros \\
\hline Flex (automóveis, camionetas e caminhões) & 340.510 litros \\
\hline Diesel (automóveis camionetas e caminhões) & 282.440 litros \\
\hline TOTAL & $\mathbf{5 . 4 9 4 . 4 3 4 ~ l i t r o s}$ \\
\hline
\end{tabular}

Extraído de: Prefeitura Municipal de São Paulo, 2007.

No Quadro I verifica-se que na maioria dos veículos foi utilizada a gasolina como combustível. Os carros a álcool e a gasolina (motor do ciclo Otto) são importantes emissores de monóxido de carbono, óxidos de nitrogênio e hidrocarbonetos, enquanto os veículos com motor de ciclo Diesel, em especial os caminhões e ônibus, são emissores de óxidos de enxofre, de nitrogênio e material particulado (fuligem), mas também, em menor grau, monóxido de carbono e hidrocarbonetos.

Um exemplo do conjunto de emissões dos poluentes clássicos se apresenta no Quadro II a seguir, e fazem parte do Relatório CETESB de 2011. 


\section{Quadro II - Fontes e características dos principais poluentes na atmosfera}

\begin{tabular}{|c|c|c|}
\hline CARACTERÍSTICAS & FONTES PRINCIPAIS & $\begin{array}{l}\text { EFEITOS GERAIS AO MEIO } \\
\text { AMBIENTE }\end{array}$ \\
\hline $\begin{array}{l}\text { Partículas Inaláveis Finas (MP 2,5) - } \\
\text { Partículas de material sólido ou líquido } \\
\text { suspensas no ar, na forma de poeira, neblina, } \\
\text { aerossol, fumaça, fuligem entre outros, que } \\
\text { podem permanecer no ar e percorrer longas } \\
\text { distâncias. Faixa de tamanho < 2,5 micra. }\end{array}$ & $\begin{array}{l}\begin{array}{l}\text { Processos } \\
\text { veículos }\end{array} \text { automotores), } \\
\text { secundário (formado na atmosfera) } \\
\text { como sulfato e nitrato, entre outros. }\end{array}$ & $\begin{array}{l}\text { Danos à vegetação, deterioração da } \\
\text { visibilidade, contaminação do solo e } \\
\text { água. }\end{array}$ \\
\hline $\begin{array}{l}\text { Partículas Inaláveis (MP 10) e Fumaça - } \\
\text { Partículas de material sólido ou líquido que } \\
\text { ficam suspensas no ar, na forma de poeira, } \\
\text { neblina, aerossol, fumaça, fuligem entre } \\
\text { outros, que podem permanecer no ar e } \\
\text { percorrer longas distâncias. Faixa de tamanho } \\
\text { < } 10 \text { micra. }\end{array}$ & $\begin{array}{l}\text { Processos de combustão (industrial e } \\
\text { veículos automotores), poeira } \\
\text { ressuspensa, aerossol secundário } \\
\text { (formado na atmosfera). }\end{array}$ & $\begin{array}{l}\text { Danos à vegetação, deterioração da } \\
\text { visibilidade e contaminação da água. }\end{array}$ \\
\hline $\begin{array}{l}\text { Partículas Totais em Suspensão (PTS) - } \\
\text { Partículas de material sólido ou líquido que } \\
\text { ficam suspensas no ar, na forma de poeira, } \\
\text { neblina, aerossol, fumaça, fuligem entre } \\
\text { outros, que podem permanecer no ar e } \\
\text { percorrer longas distâncias. Faixa de tamanho } \\
<100 \text { micra. }\end{array}$ & $\begin{array}{l}\text { Processos industriais, veículos } \\
\text { motorizados (exaustão), poeira de rua } \\
\text { ressuspensa, queima de biomassa. } \\
\text { Fontes naturais: pólen, aerossol, } \\
\text { marinho e solo. }\end{array}$ & $\begin{array}{l}\text { Pode levar à formação de chuva } \\
\text { ácida, causar corrosão aos materiais } \\
\text { e danos à vegetação: folhas e } \\
\text { colheitas. }\end{array}$ \\
\hline $\begin{array}{l}\text { Dióxido de Enxofre (SO2) Gás incolor, } \\
\text { com forte odor, semelhante ao gás produzido } \\
\text { na queima de palitos de fósforos. Pode ser } \\
\text { transformado a SO3, que na presença de vapor } \\
\text { de água, passa rapidamente a H2SO4. É um } \\
\text { importante percursos dos sulfatos, um dos } \\
\text { principais componentes das partículas } \\
\text { inaláveis. }\end{array}$ & $\begin{array}{l}\text { Processos que utilizam queima de óleo } \\
\text { combustível, refinaria de petróleo, } \\
\text { veículos a diesel, produção de polpa e } \\
\text { papel, fertilizantes. }\end{array}$ & $\begin{array}{l}\text { Pode levar à formação de chuva } \\
\text { ácida, causar corrosão aos materiais } \\
\text { e danos à vegetação: folhas e } \\
\text { colheitas. }\end{array}$ \\
\hline $\begin{array}{l}\text { Dióxido de Nitrogênio (NO2) Gás marrom } \\
\text { avermelhado, com odor forte e muito irritante. } \\
\text { Pode levar à formação de ácido nítrico, } \\
\text { nitratos (o qual contribui para o aumento das } \\
\text { partículas inaláveis na atmosfera) e compostos } \\
\text { orgânicos tóxicos. }\end{array}$ & $\begin{array}{l}\text { Processos de combustão envolvendo } \\
\text { veículos automotores, processos } \\
\text { industriais, usinas térmicas que utilizam } \\
\text { óleo ou gás, incinerações. }\end{array}$ & $\begin{array}{l}\text { Pode levar à formação de chuva } \\
\text { ácida, danos à vegetação e à } \\
\text { colheita. }\end{array}$ \\
\hline $\begin{array}{l}\text { Monóxido de Carbono (CO) Gás incolor, } \\
\text { inodoro e insípido. }\end{array}$ & & $\begin{array}{l}\text { Combustão incompleta em veículos } \\
\text { automotores. }\end{array}$ \\
\hline $\begin{array}{l}\text { Ozônio (O3) Gás incolor, inodoro nas } \\
\text { concentrações ambientais e o principal } \\
\text { componente da névoa fotoquímica. }\end{array}$ & $\begin{array}{l}\text { Não é emitido diretamente para a } \\
\text { atmosfera. } \\
\text { fotoquimicamente pela radiação solar } \\
\text { sobre os óxidos de nitrogênio e } \\
\text { compostos orgânicos voláteis. }\end{array}$ & $\begin{array}{l}\text { Danos às colheitas, à vegetação } \\
\text { natural, plantações agrícolas; plantas } \\
\text { ornamentais. }\end{array}$ \\
\hline
\end{tabular}

Extraído de: Relatório CETESB, 2011 
Estudos realizados pela Fundação SEADE (2009), mostram que o número de veículos na cidade de São Paulo cresceu quatro vezes mais do que a população paulista no período de 2002-2006.

As mesmas tendências indicadas anteriormente, também foram registradas na Região Metropolitana de São Paulo, com diferentes intensidades: $23 \%$ (vinte e três por cento) de aumento na frota de veículos e $72 \%$ (setenta e dois por cento) na frota de motocicletas, entre esses anos.

Tudo isso leva à degradação do ecossistema gerando não só danos para o meio ambiente como para a saúde do indivíduo e das populações que nele vivem.

O que define um ecossistema é o equilíbrio, uma harmonia relacional entre os diversos grupos de seres vivos que dele fazem parte. Chamamos de sistemas ecológicos ou ecossistemas qualquer unidade (biossistema) que abranja todos os organismos que funcionem em conjunto (a comunidade biótica) numa dada área, interagindo com o ambiente físico de tal forma que um fluxo de energia produza estruturas bióticas claramente definidas e uma ciclagem de materiais, entre as partes vivas e não-vivas. A Terra é um grande ecossistema e alterações ambientais produzidas em um local, podem afetar todo o Planeta (ODUM, 1988, p.9).

REIGOTA (2009 p.36), define meio ambiente como um lugar determinado e/ou percebido onde estão em relação dinâmica e em constante interação os aspectos naturais e sociais. Essas relações acarretam processos de criação cultural e tecnológica e processos históricos e políticos de transformações da natureza e da sociedade.

Para REIGOTA (2009 p.16), o ser humano contemporâneo vive profundas dicotomias; dificilmente se considera um elemento da natureza, mas um ser a parte, como um observador e/ou explorador dela.

Porém, para que o homem comece a perceber suas ações sejam elas corretas ou não, ele precisa sentir-se parte deste meio para que assim possa agir com mais cuidado pensando nas futuras gerações. 


\subsection{Educação Ambiental}

Nessas circunstâncias, um dos principais e mais poderosos instrumentos de intervenção de que se dispõe para obtenção de resultados a médio e longo prazo é a educação da população.

Segundo LEFF (2003, p.145), a educação é talvez o único modo de tender para uma cultura ambiental. A educação para aprender da complexidade ou para aprender a aprender a complexidade ambiental.

O autor refere que a educação é e sempre será o veículo do conhecimento ou o procedimento para adquiri-lo, brigamos agora por uma educação diferente, que se proponha a unir 0 desunido, relacionar 0 arbitrariamente separado.

Para PELICIONI (2004, p.467-468), a educação ambiental, como processo de educação política busca formar para que a cidadania seja exercida e para uma ação transformadora, a fim de melhorar a qualidade de vida da coletividade. A abordagem sociocultural permite que a ação proativa e transformadora, proposta pela educação ambiental, se efetive, já que implica em formação para uma reflexão crítica.

A autora cita ainda que: "não é o educador que educa, mas o educador é aquele que cria condições para que as ideias, o conhecimento, sejam incorporadas pelo educando. Esse conhecimento, para fazer parte da vida do educando, precisa ser aceito como verdade, precisa ser valorizado e corresponder às necessidades sentidas. O educador estimula o educando que, motivado, valoriza as ideias, de modo a ter certeza que elas serão significativas para sua vida" (PELICIONI, 2004, p.468).

A Educação poderá contribuir para o encaminhamento de soluções para os problemas - contando com o apoio da ciência e da tecnologia e da legislação mas para tal, deve ter como base a ética, a igualdade, a justiça e a solidariedade. 
Segundo FREIRE (2011, p.33), não é possível fazer uma reflexão sobre o que é a educação sem refletir sobre o próprio homem. A educação, portanto, implica uma busca realizada por um sujeito que é o homem. O homem deve ser o sujeito de sua própria educação. Não pode ser o objeto dela. Por isso, ninguém educa ninguém.

FREIRE (2011 p.34), segue dizendo que por outro lado, a busca deve ser algo e deve traduzir-se em ser mais: é uma busca permanente de "si mesmo" (eu não posso pretender que meu filho seja mais em minha busca e não na dele). Esta busca deve ser feita com outros seres que também procuram ser mais e em comunhão com outras consciências, caso contrário se faria de umas consciências objetos de outras.

Para MORIN (2005, p.47) a educação do futuro deverá ser o ensino primeiro e universal, centrado na condição humana. Estamos na era planetária; uma aventura comum conduz os seres humanos, onde quer que se encontrem. Estes devem reconhecer-se em sua humanidade comum e ao mesmo tempo reconhecer a diversidade cultural inerente a tudo que é humano.

O autor completa explicitando que "conhecer o humano é, antes de mais nada, situá-lo no universo, e não separá-lo dele. Todo conhecimento deve contextualizar seu objeto, para ser pertinente. Quem somos? É inseparável de Onde estamos? De onde viemos? e Para onde vamos".

Registros, estudos e denúncias de problemas ambientais decorrentes da ação antrópica vêm acontecendo desde a Antiguidade, acompanhados pela instituição de leis, decretos, normas de caráter proibitivo ou disciplinar da interferência humana sobre o ambiente (MCCORMICK, 1992).

Como afirma DIAS (1998), muitas vezes coube à Educação ser o agente de mudanças de situações indesejáveis na sociedade, e por sua natureza integradora, a ela se associam as chamadas "educações" sexual, para o trânsito, para a saúde, como também a ambiental.

O livro Primavera Silenciosa, da bióloga Raquel Carson, publicado em 1962, reunia uma série de narrativas sobre as desgraças ambientais que estavam ocorrendo em várias partes do mundo, promovidas pelo modelo de 
"desenvolvimento" econômico então adotado, e alertava a comunidade internacional para o problema. Rios mortos, transformados em canais de lodo, o ar das cidades envenenado pela poluição generalizada, destruição das florestas, solos envenenados por biocidas, águas contaminadas e tantas outras mazelas compunham, enfim, um quadro de devastação sem precedentes na existência da espécie humana (DIAS, 2011, p.73-74).

O mesmo autor menciona que a partir da publicação do trabalhodenúncia de Rachel Carson, a temática ambiental passaria a fazer parte das inquietações políticas internacionais, e o movimento ambientalista mundial iria tomar um novo impulso, promovendo uma série de eventos que formariam a sua história.

Dentre os encontros mundiais promovidos, na área ambiental destaca-se a Conferência de Estocolmo (Conferência das Nações Unidas sobre o Ambiente Humano), organizada pela ONU (1972), que reuniu representantes de 113 países e se constituiu em um marco histórico decisivo para a busca das soluções dos problemas ambientais mostrando que a educação tinha um papel fundamental nesse sentido.

Entretanto, reconheceu-se, na época, que a Educação então vigente pelas suas características de rigidez e distanciamento das realidades da sociedade, e até pela situação porque passava todo o mundo, não seria capaz de promover as mudanças necessárias. Surgiria então a Educação Ambiental (EA) como um "novo" processo educacional que deveria ser capaz de executar aquela tarefa (DIAS, 2011, p.74).

No inicio dos anos 1990, a educação ambiental era uma jovem adolescente mimada, em evidência, simpática aos meios de comunicação de massas e às agências internacionais. Com isso foi adulada por pessoas e correntes políticas, filosóficas e científicas que pouco sabiam dela e que em ocasiões anteriores the foram hostis (REIGOTA, 1998, p.22).

O autor comentou que a educação ambiental recebeu uma significativa corrente de adeptos que traziam consigo, evidentemente, as suas antagônicas e conflitantes heranças políticas, filosóficas, científicas e religiosas. 
Segundo LAYRARGUES (2009, p.25), educação ambiental é uma prática que dialoga com a questão ambiental. E no senso comum, essa prática visa a uma mudança de valores, atitudes e comportamentos para 0 estabelecimento de outra relação entre o ser humano e a natureza, que deixe de ser instrumental e utilitarista, para se tornar harmoniosa e respeitadora dos limites ecológicos.

Ainda para o autor, as questões sociais e ambientais são indissociáveis, apesar de serem tratadas separadamente por uma leitura ideológica que as dicotomizou. A realidade foi simplificada e acabamos nos acostumando a ver limitadamente, por um lado, as questões sociais, e por outro, as questões ambientais. Por se tratar de uma outra visão da realidade, é perfeitamente compreensível a dificuldade de se ver questões sociais e ambientais associadas (LAYRARGUES 2009, p.26).

Para STAPP et al. (1969), citado por DIAS (2011, p.98), "a educação ambiental foi definida como um processo que deveria ter como objetivo a formação de cidadãos, cujos conhecimentos acerca do ambiente biofísico e seus problemas associados pudessem alertá-los e habilitá-los a resolver seus problemas".

A Internacional Union for the Conservation of Nature (IUCN, 1970), definiu Educação Ambiental como um processo de reconhecimento de valores e clarificação de conceitos, voltado para o desenvolvimento de habilidades e atitudes necessárias à compreensão e apreciação das inter-relações entre o homem, sua cultura e seu entorno biofísico.

Para PHILIPPI JR e PELICIONI, (2005), a educação ambiental deve ser um processo contínuo de construção da cidadania, possibilitando aos indivíduos e à coletividade consciente atuar na busca de soluções para problemas que afetam a todos. Para que isso ocorra, a capacitação técnica por meio da construção de conhecimentos, da formação de atitudes e de habilidades, objetivos da educação ambiental, deve estar voltada para o desenvolvimento de ações que garantam a sustentabilidade. 
Para REIGOTA (2009, p.12), "a educação ambiental não deve estar relacionada apenas com os aspectos biológicos da vida, ou seja, não se trata apenas de garantir a preservação de determinadas espécies animais e vegetais e dos recursos naturais", embora essas questões (biológicas) sejam extremamente importantes e devam receber muita atenção.

O autor alerta que: "quando afirmamos e definimos a educação ambiental como educação política, estamos dizendo que o que deve ser considerado prioritariamente na educação ambiental é a análise das relações políticas, econômicas, sociais e culturais entre a humanidade, tendo em vista superar os mecanismos de controle e de dominação que impedem a participação livre, consciente e democrática de todos" (REIGOTA, 2009, p.13).

Em outra publicação, REIGOTA (2010, p.11), afirma que a educação ambiental é uma proposta que altera profundamente a educação como a conhecemos, não sendo necessariamente uma prática pedagógica voltada para a transmissão de conhecimentos sobre ecologia. Trata-se de uma educação que visa não só a utilização racional dos recursos naturais (para ficar só nesse exemplo), mas basicamente a participação dos cidadãos nas discussões e decisões sobre a questão ambiental.

Segundo TOLEDO (2002), durante algum tempo perdurou uma visão fragmentada do meio ambiente que enfatizava apenas seus aspectos físiconaturais e/ou ecológicos, o que se refletia nos programas de educação ambiental, porém, esta visão parece estar sendo superada, ao menos nas discussões teóricas. Sabe-se que uma compreensão integrada do meio ambiente é fundamental para buscar as raízes dos problemas socioambientais e para o desenvolvimento de programas com esta preocupação.

Para ZIAKA, SOUCHON e ROBICHON (2003), a educação ambiental aqui apresentada, além de não suscitar a preocupação apenas com problemas relativos a impactos ambientais e ao uso dos recursos naturais, também considera que não basta avaliar danos e riscos, propõe que se vá além da análise e reflexão, assumindo plenamente a vontade de agir. 
No entanto, entende-se que a educação ambiental não deve estar voltada apenas para ações corretivas, mas, sobretudo para reconstrução de valores e para a transformação da realidade como um todo.

SAUVÉ (2003, p.44-45), destaca que a educação relativa ao meio ambiente (ERMA ou Educação Ambiental) visa a reconstrução da rede de relações entre as pessoas, o grupo social e o meio ambiente. $O$ objetivo da Educação Ambiental consiste no desenvolvimento de competências críticas, éticas, estratégicas, estéticas entre outras, tendo em vista a relação com o meio ambiente.

Para a autora a educação ambiental é um processo essencial para o desenvolvimento humano, para o desenvolvimento social integral; neste aspecto, ela faz apelo a escolhas pedagógicas apropriadas (p.46).

GOMIDE e SERRÃO (2004, p.12), consideram que a educação ambiental pode ser considerada um instrumento de promoção da saúde, "capaz de criar condições à participação dos diferentes segmentos sociais, tanto na formulação de políticas, quanto na aplicação das decisões que afetam a qualidade do meio natural e social e, consequentemente, influenciam as condições de saúde".

Já MEDINA (2000, p.87), destaca que "as propostas de educação ambiental pretendem aproximar a realidade ambiental das pessoas, conseguir que elas passem a perceber o ambiente como algo próximo e fundamental nas suas vidas. Deve verificar ainda, que cada pessoa tem um importante papel a cumprir na preservação e transformação do ambiente em que vivem. Levá-las a compreender que o futuro, como construção coletiva, depende de decisões políticas e econômicas que sejam definidas hoje e que irão interferir nas possibilidades de definição de novos modelos de desenvolvimento, capazes de conciliar a justiça e o equilíbrio ecológico, que permitam manter a base do rico substrato natural e cultural dos países, melhorando efetivamente a qualidade de vida da população. 
Segundo PELICIONI (2009, p.754), a educação ambiental é uma ideologia que conduz à melhoria da qualidade de vida e ao equilíbrio dos ecossistemas para todos os seres vivos. Assim, mais do que um instrumento de gestão ambiental, ela deve se tornar uma filosofia de vida, que se expressa como uma forma de intervenção em todos os aspectos sociais, econômicos, políticos, culturais, éticos e estéticos.

Em outra publicação PELICIONI diz ainda que a educação depende de adesão voluntária, para formar e preparar cidadãos para a reflexão crítica e para uma ação social corretiva ou transformadora do sistema, de forma a tornar viável o desenvolvimento integral dos seres humanos. Ela é fundamental visto que, infelizmente, é no trânsito que algumas pessoas descarregam suas frustrações e problemas pessoais.

Cada autor expôs suas ideias sobre a Educação Ambiental (EA) e como ela pode contribuir para a melhoria de vida das populações existentes.

Autores como Paulo Freire e Edgard Morin discorreram sobre a importância do ser humano dentro desse processo educativo e como essa evolução deve acontecer.

Outros citaram aspectos relacionados às práticas pedagógicas, relações entre as pessoas, condição de participação, cidadania e empoderamento da população como forma relevante de se praticar a Educação Ambiental.

A EA para ser efetiva deverá resgatar, conhecer e respeitar as culturas e valores de cada local ou região.

Quando implementada deverá contemplar todos os envolvidos no processo, orientando como cada um poderá contribuir para que o espaço onde vive se torne mais saudável dentro das normas e leis ambientais regidas para cada Estado, Cidade ou Município. 


\subsubsection{A Legislação vai complementar a ação educativa}

Segundo DIAS (2011, p. 201), o Brasil é o único país da América Latina que tem uma política nacional específica para a Educação Ambiental. Sem dúvida foi uma grande conquista política e essa não se deu sem sacrifícios de diversos atores envolvidos na causa.

No entanto, ela deixou a desejar por ocasião de sua regulamentação, pois não prevê o financiamento das ações conforme deveria.

Em 1999, instituiu-se a Política Nacional de Educação Ambiental, pela Lei Federal 9795, de 25 de abril, a qual foi regulamentada pelo Decreto 4281, somente em 25 de junho de 2002. Segundo a lei, entendem-se por educação ambiental "os processos por meio dos quais os indivíduos e a coletividade constroem valores sociais, conhecimentos, habilidades, atitudes e competências voltadas para a conservação do meio ambiente, bem de uso comum do povo, essencial à sadia qualidade de vida e sua sustentabilidade" (BRASIL, 1999, Cap. I, Art 1ํ).

Embora o estabelecimento da Política Nacional de Educação Ambiental no Brasil represente um avanço para a discussão desta temática, esta definição apresenta certa fragilidade, uma vez que no conceito apresentado enfatiza apenas a conservação do meio ambiente e não aborda aspectos relacionados ao caráter político da educação ambiental e seu potencial transformador de sujeitos e de realidades.

E no Brasil foi sancionada a Lei 12.633 de 14 de maio de 2012, que "Institui o dia nacional da Educação Ambiental".

Muitos eventos sobre EA vêm sendo realizados ao longo dos anos desde 1972 tentando provocar discussões sobre o assunto no âmbito internacional, nacional, regional entre outros.

Vale aqui destacar alguns que tiveram relevância para que a temática ganhasse uma dimensão mundial, conforme referido por (DIAS, 2011). 
Em 1975 no Encontro de Belgrado, ex-lugoslávia, em evento promovido pela Unesco, foi elaborada uma carta que formulou os princípios e as orientações para o Programa Internacional de Educação Ambiental (PIEA).

A Primeira Conferência Intergovernamental sobre Educação Ambiental foi realizada em Tbilisi, capital da Georgia, ex-Russia, em 1977, também organizada pela UNESCO, em cooperação com o Programa das Nações Unidas para o Meio Ambiente (PNUMA), e constituiu-se em um marco histórico para a evolução da EA.

Outros eventos internacionais como: o Seminário sobre EA na Costa Rica em 1979, o Congresso Internacional sobre Educação e Formação Ambientais ocorrido em Moscou, em 1987, e o Seminário Latino-Americano de EA na Argentina, em 1988, também contribuíram para disseminar as propostas sobre a temática.

Cabe citar o Protocolo de Quioto firmado em 1997, no Japão teve importância e culminou na decisão por consenso (1/CP.3) de adotar um Protocolo segundo o qual os países industrializados reduziriam suas emissões combinadas de gases de efeito estufa em pelo menos $5 \%$ (cinco por cento) em relação aos níveis de 1990, até o período entre 2008 e 2012. Esse compromisso, com vinculação legal, prometia produzir uma reversão da tendência histórica de crescimento das emissões iniciadas nesses países, há cerca de 150 anos. De lá para cá aconteceram muitas atividades que precisam ser relatadas.

Em Johannesburgo, na África do Sul, em 2002, realizou-se a Conferência das Nações Unidas para o Desenvolvimento Sustentável.

No Brasil ocorreram alguns eventos importantes como: Encontro Nacional de Políticas e Metodologias para a EA, promovido pelo Ministério da Educação e Cultura (MEC) e Secretaria do Meio Ambiente (SEMAM) em 1991, bem como encontros Técnicos de EA nas diversas regiões do Brasil.

O mais importante desses eventos foi a Conferência do Rio, ou Rio/92 como ficou conhecida essa Conferência das Nações Unidas sobre o Meio Ambiente e Desenvolvimento. Essa Conferência teve importância pois mostrou 
a necessidade do enfoque interdisciplinar e da priorização das seguintes áreas de programas:

- Reorientar a educação para o desenvolvimento sustentável;

- Aumentar os esforços para proporcionar informações sobre o meio ambiente de modo que possam promover a conscientização popular;

Assim, a Rio/92 corroborou com as recomendações de Tbilisi para a EA, mas até o presente, a Conferência de Tbilisi continua sendo a referência internacional para o desenvolvimento e práticas de atividades de Educação Ambiental.

Segundo REIGOTA (2009, p.26), essa Conferência conhecida como Rio+10, teve como objetivo avaliar as aplicações e progressos das diretrizes estipuladas no Rio de Janeiro. Realizada em 2002 num momento de tensão internacional, logo após o atentado de 11 de setembro e, poucos meses antes da invasão americana no Iraque, essa reunião foi considerada um fracasso por uns e por outros uma possibilidade de encontros, debates e elaboração de estratégias comuns, apesar do descrédito público das Nações Unidas.

Relata o autor que a Rio+10 teve o mérito de possibilitar aos cidadãos do continente africano uma participação ativa, expondo as mazelas em que vivem, como as inúmeras guerras civis, o imenso número de pessoas contaminadas com o HIV, a poluição da água e do ar, o analfabetismo e a pobreza extrema de grande parte da população.

Agora em 2012, no período de 13 a 22 de Junho, exatamente após 20 anos, realizou-se a Conferência das Nações Unidas para o Desenvolvimento Sustentável - Rio+20, que teve como objetivo principal garantir o compromisso político internacional para o desenvolvimento sustentável. Este evento foi divulgado em toda forma de mídia para que tivesse pleno êxito. Durante nove dias, milhares de atividades foram realizadas no período que a antecedeu e durante a Rio + 20, ocorreram, em todo o Rio de Janeiro, mais de 500 eventos oficiais e paralelos no Centro de Convenções Riocentro, onde a conferência ocorreu. A Rio + 20 foi a maior conferência da Organização das Nações Unidas (ONU) já realizada, com ampla participação de líderes de empresas, governos 
e sociedade civil, assim como, oficiais da ONU, acadêmicos, jornalistas e o público em geral United Nations Conference on Sustainable Development (Uncsd, 2012).

Mais de 513 bilhões de dólares foram mobilizados em compromissos para o desenvolvimento sustentável, inclusive nas áreas de energia, transportes, economia verde, redução de desastres, desertificação, água, florestas e agricultura e 692 acordos voluntários registrados por governos, empresas, grupos da sociedade civil, universidade e outros.

O Jornal da Universidade de São Paulo-USP datado do período de 29 de agosto a 4 de setembro de 2012, p.20, trouxe informações de como a Universidade se organizou para apresentar, na Conferência da ONU, o que tem feito pela sustentabilidade, assim como mostrou a visão de futuro que norteará suas ações nas próximas décadas.

Nessa publicação apareceu um depoimento do francês Brice Lalonde, coordenador executivo da Conferência, que disse: o Brasil assumiu uma posição de liderança nas negociações que aconteceram de 4 a 6 de junho, do ano 2012. Os debates das delegações oficiais ocorreram no Riocentro, Barra da Tijuca, zona oeste do Rio de Janeiro, enquanto as organizações nãogovernamentais ficaram em área mais central, no Aterro do Flamengo.

Outro evento importante foi a Conferência Anual da ONU (COP 18) realizada no Catar, Doha, no período de 26/11 a 8/12/2012 que renovou o Protocolo de Quioto, aqui já citado, mantendo-o como único plano que gera obrigações legais para enfrentamento do aquecimento global, estabelecendo que as nações desenvolvidas diminuam a emissão de gases-estufa entre 2013 e 2020. O pacto no entanto, não estipula o volume da redução, exclui os grandes poluidores emergentes como China e Índia, e não conta com a adesão dos Estados Unidos, Japão, Rússia e Canadá. Somente a União Européia e Austrália participam (RADIS, 2013).

Todos esses acontecimentos importantes ocorridos no passar dos anos vêm dando subsídios para que cada vez mais se possa implementar ações de Educação Ambiental no cotidiano das populações. 
No nosso estudo a preocupação, entre outros aspectos, é fornecer subsídios para que se adotem políticas para racionalizar o uso de parte dos veículos existentes atualmente na Região Metropolitana da cidade de São Paulo.

O que cada um de nós pode fazer então para tentar minimizar a poluição do ar causada por esses veículos?

Algumas das possibilidades existentes já são conhecidas e praticadas, umas em maior outras em menor escala, tais como: rodízio de veículos, uso de bicicletas e melhoria do transporte público, incluindo metrô, ônibus e trem, para diminuir a poluição do ar em grandes cidades. Deve-se investir também no uso compartilhado de automóveis, o que exige uma atuação voltada para a educação ambiental dos usuários e gestores e sua consequente mudança de atitudes.

Reportagem exibida em maio de 2009, aqui no Brasil no Programa Cidades e Soluções da Globo News, mostrou que esta experiência de compartilhar automóveis tem sido usada com muito sucesso em alguns países da Europa. Na França existe um site chamado co-voiturage.fr, que em português quer dizer compartilhamento de veículos. Conta atualmente com 200 mil pessoas inscritas. Pessoas que participam deste programa de carona disseram perceber que as vantagens tem sido inúmeras, tais como: economia nos gastos com pedágio e com gasolina, têm sentido o prazer de conhecer outras pessoas e fazer novos amigos. Há depoimentos de pessoas que dizem que com três anos de uso do programa foi feita uma economia de 9.000 mil euros tendo conseguido até quitar as parcelas de compra de seu carro. Outros descrevem que em determinadas épocas do ano onde a maioria das pessoas tendem a viajar muito, a carona é mais uma opção, já que muitas vezes não conseguem encontrar passagem de ônibus ou trem para seus destinos.

Quatro anos após inaugurar um sistema coletivo de bicicletas, a capital francesa lançou agora o autolib, um sistema de carros elétricos para aluguel de moradores e turistas. Além de ser ecologicamente correta, a invenção contribui para melhorar muito o trânsito da cidade. 
Betrand Delanoe, hoje Prefeito de Paris, considera ser esse um grande desafio. Disse que os moradores da cidade precisam de metrô, bicicleta, trem, navegação fluvial e não precisam possuir um carro. É preciso, segundo ele, que se forneça um serviço de carros não poluentes. Isso vai ser muito mais econômico em termos de poluição e em termos de utilização de espaço, vai gerar menos engarrafamentos, porque o carro vai ser utilizado por muitos usuários. Certamente, em termos de poluição, haverá zero emissão de gás carbônico, o que será excelente. O Prefeito espera que cada vez mais os parisienses deixem de ter seu próprio automóvel e passem a usar o sistema de aluguel (PROGRAMA CIDADES E SOLUÇÕES, 2011).

Para SYLVAIN MARTY, diretor do autolib a ideia é que daqui 5 anos menos 20 mil automóveis estejam fora de circulação (Programa Cidades e Soluções exibido em 21/12/2011).

Em São Paulo, algumas iniciativas como mapear as rotas que possam servir para a circulação de bicicletas bem como informar os pedestres sobre seus direitos e deveres no trânsito, vem acontecendo com frequência.

Pode-se citar como necessidades para a melhoria da mobilidade na cidade de São Paulo, reorganizar urgentemente a rede ferroviária, rodoviária e hidroviária além de construir mais ciclovias (para bicicletas) e aumentar a malha metroviária, criar mais corredores para ônibus, veículos leves sobre trilhos (VLT) entre outros.

O intenso uso de veículos automotores nos grandes centros urbanos e suas sérias consequências gerou a ideia do uso da Carona Solidária, que deve ser feito de forma constante e sistematizada.

Acredita-se que a Educação Ambiental dos motoristas e dos passageiros visando a sua mudança de atitude, vai contribuir para que passem a aderir a programas de Carona Solidária, diminuindo o número de carros nas ruas.

Essa pode ser uma boa alternativa, entre outras, para minimizar o problema da poluição do ar nas grandes cidades. 


\subsection{O Programa de Carona Solidária}

De acordo com a Sra MARIA DE LOURDES R. FREIRE, (1998, p.38) Secretária de Meio Ambiente do Governo do Estado de São Paulo naquele ano "o transporte solidário esteve entre as ações que visavam melhorar a qualidade do ar na cidade de São Paulo, buscando reduzir a emissão de poluentes atmosféricos por parte dos veículos automotores.

Segundo ela, já em 1998 a ocupação média dos veículos era de 1,5 pessoas por automóvel. Em decorrência disso, verificou-se imensos congestionamentos, com recordes de $241 \mathrm{Km}$, aumento da poluição do ar, maior tempo de viagem da população que circula pela cidade e agravamento de problemas de saúde, como o estresse.

A intenção era incentivar o hábito do transporte compartilhado, a "carona" entre os colegas de trabalho, pessoal das escolas, bairros, para diminuir o número dos veículos em circulação e consequentemente, a poluição.

Carona Solidária em língua inglesa: (Carpool ou Carpooling) é o uso compartilhado em alternância de um automóvel particular por duas ou mais pessoas, para viajar juntos durante o horário de rush. Faz com que economizem nas despesas de viagem, colaborando para a redução do congestionamento de veículos e diminui a poluição do ar e a emissão de gases do efeito estufa.

Rush, é uma palavra inglesa que no Brasil de décadas atrás, referia-se aos horários de pico no trânsito - o começo e o fim do dia. O rush, pela quantidade de carros e morosidade de trânsito, fazia naquela época, com que uma pessoa chegasse 15 minutos mais tarde a qualquer lugar. Esses 15 minutos eram sinal de que as coisas não iam muito bem. Falar em atraso semelhante hoje equivale a dizer que quase chegamos na hora, quase conseguimos ser pontuais. O tempo gasto para locomoção nos grandes centros urbanos tem piorado ano a ano (REVISTA VIDA SIMPLES, 2011, p.19). 
Acredita-se que a Carona Solidária é muito mais do que o uso compartilhado do automóvel. É um meio para que as pessoas criem vínculos e possam interagir de maneira mais amigável ou seja, estar em contato com o outro. As pessoas tendem a conversar mais, contanto suas histórias, angústias, problemas. Essa convivência diária poderá trazer com a companhia de outras pessoas, maior disposição para ao chegar ao seu destino, seja esse o trabalho ou a escola. Questões econômicas como dividir os gastos de gasolina, pedágio, entre outros, podem também vir a somar positivamente com o uso da carona.

Pelo fato de vivermos em uma metrópole onde a insegurança, o stress e o medo nos distanciam cada vez mais de compromissos sociais, ao estarmos de carona com outra pessoa, o trajeto torna-se mais seguro pelo fato de não estarmos sozinho.

De acordo com LIPP e ROCHA (1996 p.63), o stress é uma reação desencadeada por qualquer evento que confunda, amedronte ou emocione a pessoa profundamente. Note que esta definição não se refere ao estressor só como algo negativo; ele pode ser também algo muito positivo que emocione a pessoa de modo marcante. Assim sendo, do mesmo modo que um acidente pode estressar alguém, uma promoção também pode gerar stress.

Permanecer muitas horas no trânsito sozinho torna as pessoas estressadas com a situação. Dessa forma percebe-se a forma negativa do estress.

O Programa de Carona Solidária já é utilizado há muitos anos em países como a França, a Alemanha, a Inglaterra, o Canadá e os Estados Unidos, com bastante sucesso. A adesão dos participantes nesses países foi bem mais rápida e intensa tendo em vista que a segurança das pessoas lá é maior.

Além de problemas de segurança física dos usuários, fator que tem contribuído muito para a falta de adesão imediata das pessoas à Carona Solidária, estão também aí relacionadas as questões culturais de cada país, incluindo os hábitos, valores, representações sociais e costumes adquiridos pelos indivíduos. 
Para OLIVEIRA (2010), o fato de "ter e sair com um carro novo, do ano" ainda é um valor para uma parcela da população; pegar ou dar carona para quem não se conhece, ou ainda sem saber como o outro irá se comportar, torna a decisão mais difícil. Talvez com o passar do tempo conseguiremos obter mudanças de atitudes das pessoas que por perceberem os benefícios trazidos com a prática da Carona Solidária ao meio ambiente e à qualidade de vida, superarão o seu medo, aderindo mais facilmente à proposta. Este estudo ainda mostrou que as questões culturais são as que mais influenciam nos hábitos das pessoas.

Uma das primeiras preocupações dos estudiosos com relação à cultura refere-se à sua origem. Em outras palavras, como o homem adquiriu este processo extrassomático que o diferenciou de todos os animais e the deu um lugar privilegiado na vida terrestre?

O conceito de cultura que GEERTZ (1989, p.10), defende, é essencialmente semiótico. Acreditando, como Max Weber, que o homem é um animal amarrado a teias de significados que ele mesmo teceu, assumimos a cultura como sendo essas teias e a sua análise; portanto, não como uma ciência experimental em busca de leis, mas como uma ciência interpretativa, à procura do significado. É justamente uma explicação que procuramos ao construir expressões sociais enigmáticas na sua superfície.

De acordo com REIGOTA (1999, p.26), com a pós-modernidade, a noção de cultura foi ampliada, não sendo mais entendida como resultado de um longo processo de elaboração, sofisticação e erudição de indivíduos, grupos sociais, ou instituições, mas sim como um processo ágil de "deglutição" cotidiana de inúmeras referências.

O autor segue dizendo que com a benéfica ampliação da noção de cultura, resta-nos definir o que estamos entendendo por cultura. Segundo HANNERZ (1992) citado por REIGOTA, a cultura tem sido usada para se referir a todas as formas de expressão; sendo assim, segundo o mesmo autor, "estudar cultura é estudar ideias, experiências, sentimentos" (p.27). 
Segundo LARAIA (2009, p. 25), no final do século XVIII e no princípio do seguinte, o termo germânico Kultur era utilizado para simbolizar todos os aspectos espirituais de uma comunidade, enquanto a palavra francesa civilization referia-se principalmente às realizações materiais de um povo.

Ambos os termos foram sintetizados por Edward Tylor, no vocábulo inglês culture, que "tomando em seu amplo sentido etnográfico é todo complexo que inclui conhecimentos, crenças, arte, moral, leis, costumes ou qualquer outra capacidade ou hábito adquirido pelo homem como membro de uma sociedade".

De acordo com KROEBER, citado por LARAIA (2009, p.48), "a cultura, mais do que a herança genética, determina o comportamento do homem e justifica as suas realizações. É o meio de adaptação aos diferentes ambientes ecológicos. Em vez de modificar para isto o seu aparato biológico, o homem modifica o seu equipamento superorgânico. Em decorrência da afirmação anterior, o homem foi capaz de romper as barreiras das diferenças ambientais e transformar toda a terra em seu habitat. $O$ autor termina dizendo que a cultura é um processo acumulativo, resultante de toda a experiência histórica das gerações anteriores. Este processo limita ou estimula a ação criativa do indivíduo".

Limitando ou não a ação criativa de cada indivíduo a cultura é individual para cada um. Sendo assim ela pode ter diversos significados dependendo de como é exposta diante da população.

Para ARANHA e MARTINS (2009, p.109), a palavra cultura tem vários significados, como cultura da terra ou cultura de uma pessoa letrada, "culta". Em antropologia, cultura significa tudo o que o ser humano produz ao construir sua existência: as práticas, as teorias, as instituições, os valores materiais e espirituais. Se o contato com o mundo é intermediado pelo símbolo, a cultura é o conjunto de símbolos elaborados por um povo.

Segundo FREIRE (2011, p.38), cultura é tudo o que é criado pelo homem. Tanto uma poesia como uma frase de saudação. A cultura consiste em recriar e não em repetir. 
A aquisição da cultura permitiu ao homem depender muito mais do aprendizado do que de agir por meio de atitudes geneticamente determinadas, ficando muitas vezes dependente de conhecimentos adquiridos por outros, para tomar suas próprias decisões.

\subsection{A Sociedade de Consumo}

O rápido avanço da tecnologia tem nos atualizado a todo momento mas também tem nos feito reféns da tão chamada sociedade de consumo, onde tudo aquilo que pensamos e queremos pode-se adquirir em um piscar de olhos.

Para ORTIGOZA e CORTEZ (2009, p.36), o termo sociedade de consumo é uma das tentativas para entender as mudanças que vêm ocorrendo nas sociedades contemporâneas e refere-se à importância que o consumo tem recebido na construção das relações sociais e na formação e fortalecimento das nossas identidades. Dessa maneira, o nível e o estilo de consumo tornamse a principal fonte de identidade cultural, de participação na vida coletiva, de aceitação em um grupo e de distinção com os demais.

As autoras argumentam que com a expansão da sociedade de consumo, amplamente influenciada pelo estilo de vida norte-americano, o consumo transformou-se em uma compulsão e um vício, estimulados pelas forças do mercado, da moda e da propaganda. A sociedade de consumo produz carências e desejos, tanto materiais quanto simbólicos e os indivíduos passam a ser reconhecidos, avaliados e julgados por aquilo que consomem, vestem ou calçam, pelo carro e pelo telefone celular que exibem em público (p.37).

Em Minnesota podemos ver um exemplo desse consumo exagerado no shopping Mall of America, com 400 mil metros quadrados - área equivalente a sete estádios dos Yankees, é um dos pontos mais concorridos dos Estados Unidos, país em que havia mais carros particulares do que motoristas habilitados em 2003 e onde o cidadão anda, em média, com 6,5 cartões de crédito no bolso (LEONARD, 2010, p.160). 
Segundo ZACARIAS (2009), a questão do consumo vem sendo pauta de estudos de diversos autores no mundo contemporâneo. Uma das correntes de repercussão está associada aos estudos culturais e às teorias da pósmodernidade. Estes estudos partem do princípio de que vivemos numa sociedade de consumo, caracterizada como sociedade simbólica, de sinais e significados, que possibilita a construção e o fortalecimento das identidades individuais e sociais por meio da aquisição de bens.

A cultura do consumo representa a importância crescente da cultura no exercício do poder. O poder de escolha do indivíduo na esfera do consumo nas sociedades pós-tradicionais tem sido campo de debate sobre a sua real liberdade de escolha ou submissão a interesses econômicos maiores que se escondem por trás do marketing e da propaganda.

Será o consumo uma arena de liberdade e escolha ou de manipulação e indução? Terá o consumidor efetivamente escolha? Ele é súdito ou soberano, ativo ou passivo, criativo ou determinado? (BARBOSA, 2010 p.33).

Para BAUDRILLARD (1991) citado por LUZZI (2012 p.35), vivemos em um contexto onde o consumo invade a vida das pessoas, suas relações, envolvem toda a sociedade e as satisfações pessoais são completamente traçadas por meio dele. Neste contexto e dentro da visão do autor, o desenvolvimento se estabelece pela incessante produção dos chamados bens de consumo duráveis, tais como os automóveis e os eletroeletrônicos.

Tudo isso nos leva a hábitos e costumes que sem percebermos nos causam certo desconforto seja socialmente ou economicamente e por consequência, nos conduz ao stress diário onde nossa saúde acaba sendo afetada, principalmente em uma metrópole como São Paulo, que é por si só uma vitrine a céu aberto para os prazeres dessa chamada "sociedade de consumo". 
Adquirir um modelo de automóvel novo cada vez que é lançado, portanto, vem atender à essa demanda criada artificialmente pela sociedade de consumo por meio da propaganda dirigida e vai proporcionar muito prazer ao consumidor passível de ser influenciado por coisas materiais, prazer no entanto logo superado por outra demanda. Prova disso é o salão do automóvel organizado atualmente no mundo todo. 


\section{2 - CENÁRIO DE ESTUDO}

\section{1 - A Cidade de São Paulo}

As autoras PASTERNAK e LEME (2010), no artigo denominado De Vila a Metrópole, explicam como se deu o crescimento da cidade de São Paulo.

A capital de São Paulo possui 11.057.629 milhões de habitantes, segundo a projeção de população que foi feita para 2010, e é o núcleo da maior região metropolitana do país, conhecida como Grande São Paulo. Com 39 municípios e perto de 20 milhões de moradores em cerca de oito mil quilômetros quadrados, a metrópole paulista concentra quase a metade dos residentes no Estado. A região está entre as seis maiores aglomerações humanas do planeta, ao lado de Tóquio (Japão), Seul (Coréia do Sul), Nova York (Estados Unidos), Cidade do México (México) e Mumbai (antiga Bombai, na Índia). Sua história quando desvendada, auxiliará a compreender a situação atual.

A cidade de São Paulo foi fundada à margem do interesse econômico e político da Coroa Portuguesa. Sua localização em um planalto de difícil acesso isolou-a do contato com Portugal e com as outras capitanias. A escolha da posição geográfica do núcleo inicial sobre uma colina, entre o rio Tamanduateí e o córrego do Anhangabaú, se deu por medo de ataques indígenas.

No fim do século XVI, a cidade continha mais ou menos 120 casas, amontoadas no alto do morro. O planalto paulista tinha sua base econômica na agricultura de subsistência, a atividade rural era mais importante do que a urbana e o local preferencial de moradia era a fazenda. A casa da cidade era reservada para visitas temporárias.

Em 1767, dois anos depois de iniciada a administração de Morgado de Mateus, realizou-se o primeiro censo. A vila, com 694 domicílios era habitada por 2.774 moradores. Em 1867, quando foram inauguradas e complementadas as obras da São Paulo Railway, que ia de Santos a Jundiaí, a população da 
cidade alcançava 19 mil moradores. A partir daí, o crescimento foi grande, em 1890 a cidade já somava 64.934 habitantes.

Em 1900, havia em São Paulo uma população de 239 mil habitantes, tendo crescido à taxa de 14\% (quatorze por cento) ao ano, entre 1890 e 1900. A cidade explodiu e os novos bondes à, tração animal tornaram evidente a expansão territorial.

E daí por diante na década de 1970, a cidade se desenvolveu cada dia pela periferia da metrópole, quando inúmeros loteamentos foram abertos atingindo os municípios vizinhos, aumentando os limites da cidade.

Foi ficando evidente que São Paulo havia deixado de ser uma grande cidade, passando a constituir um Centro Metropolitano, polo de atração de um conjunto de cidades.

Com todo esse desenvolvimento na Capital, os congestionamentos de trânsito aumentavam e os principais planos de longo prazo - do Metrô e o Plano Diretor de Desenvolvimento Integrado - propunham um sistema de vias expressas em malha e não mais radiocêntricas, como previsto no Plano de Avenidas.

O metrô foi lentamente sendo construído atendendo ao Centro Expandido e a algumas áreas da periferia. A linha de trens de passageiros paralela à Marginal do Rio Pinheiros, também servindo à periferia, integrou-se ao Metrô no fim da década de 1990, com a construção de algumas estações. A grande obra de infraestrutura da década de 2000-2010 foi, sem dúvida, o Rodoanel, articulando as estradas e outros polos estaduais que, se por um lado facilitou o acesso, por outro criou grandes problemas ambientais por onde passou.

Ainda falta muito para se ter um meio ambiente saudável na cidade. A poluição do ar por emissão industrial foi controlada, mas aquela provocada pelos veículos automotores cresce proporcionalmente à frota de automóveis, devido ao transporte público deficiente. 
Como em todos os centros urbanos expandidos existe uma grande oferta de serviços, como também há uma deficiência em outros como no caso do transporte público.

Isso em parte se deve ao crescimento desordenado onde a população é afastada do seu local de (trabalho, estudo, entre outras atividades) para dar lugar ao desenvolvimento seja local ou regional.

Em São Paulo não foi diferente, a cidade possui hoje inúmeros serviços de saúde, incluindo hospitais públicos e privados que são em sua maioria, dentre outros, locais de trabalho de parte dessa população.

\section{2 - O Instituto do Câncer do Estado de São Paulo (ICESP)}

Entre os hospitais públicos, destacava-se o Instituto do Câncer do Estado de São Paulo (ICESP) localizado na Zona Oeste da cidade.

O Instituto do Câncer do Estado de São Paulo Octavio Frias de Oliveira é um serviço de saúde que tem contribuído muito para a pesquisa, o ensino e a qualidade do atendimento ao paciente com câncer. Seu vínculo com a Faculdade de Medicina da USP e, como o Hospital das Clinicas da (FMUSP), possibilitará a sua inserção no maior sistema universitário de saúde do país reconhecido pela sua excelência - e um dos principais do mundo.

A Instituição Hospitalar ocupa integralmente um edifício moderno com 29 pavimentos construídos no ponto mais alto da área urbana da capital paulista. Possui ainda quatro andares de subsolo e um heliponto.

Inaugurado em 6 de maio de 2008 como o mais completo centro de referência em pesquisa, tratamento e desenvolvimento científico para o câncer no Brasil, o ICESP foi concebido, equipado e está sendo gerido por profissionais de notória qualificação que trabalham com entusiasmo e determinação para transformá-lo em um dos mais avançados e humanizados centros oncológicos do mundo. 
Atualmente o Instituto do Câncer do Estado de São Paulo Octavio Frias de Oliveira (ICESP) conta com 3000 (três mil) funcionários.

Esta Instituição constitui-se no cenário de estudo da presente pesquisa.Figura 3.

Figura 3 - Instituto do Câncer do Estado de São Paulo (ICESP) local da pesquisa.

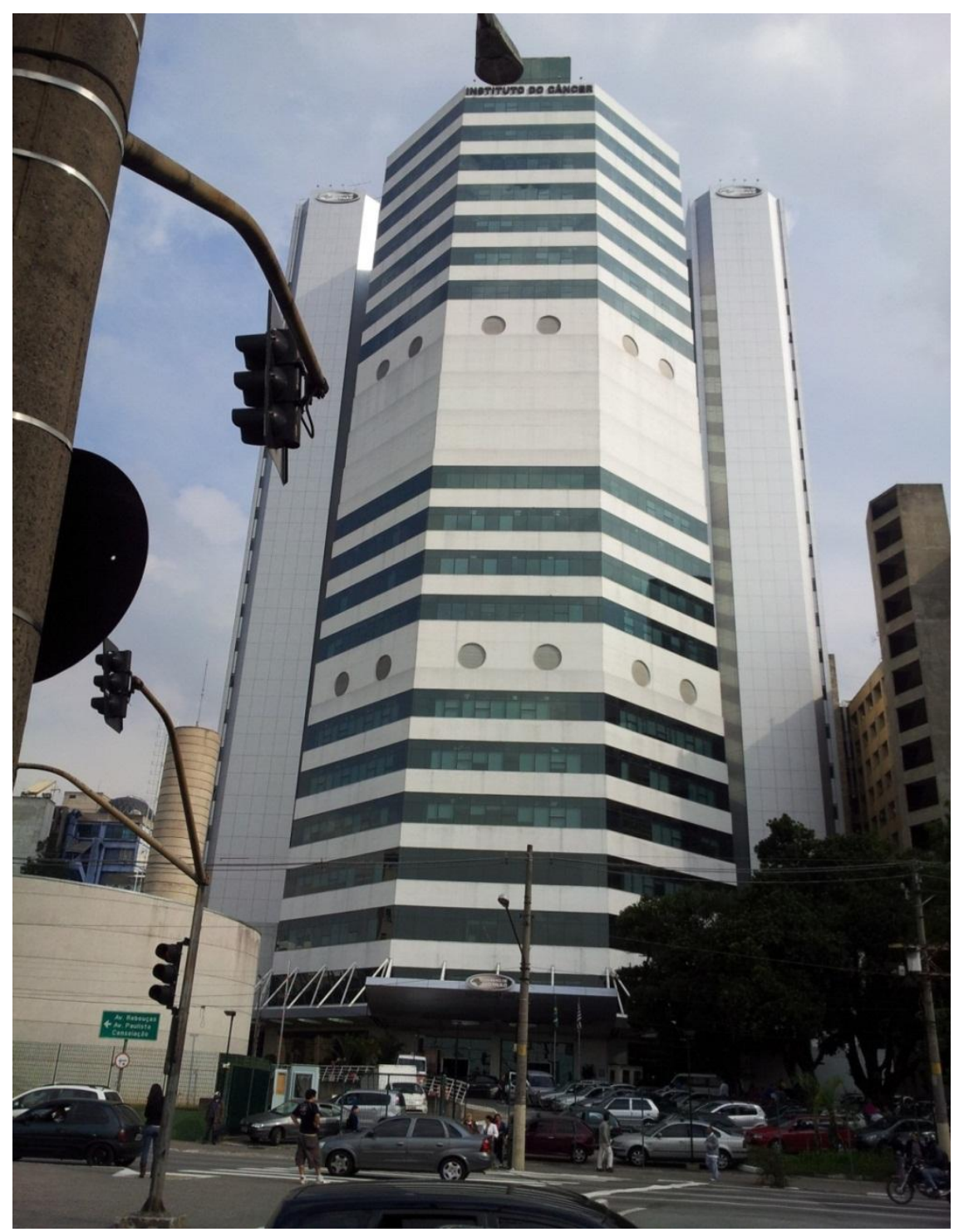

Foto: Oliveira SC tirada em 2012 


\section{3 - OBJETIVOS}

Diante do exposto decidiu-se realizar uma investigação que teve como objetivos:

a) Identificar os motivos que levam ou não as pessoas a participarem de um programa de Carona Solidária na cidade de São Paulo-SP.

b) Verificar seus conhecimentos, opiniões e percepções sobre as relações entre a saúde e o meio ambiente; e em particular, sobre o uso do automóvel e a poluição ambiental.

c) Verificar em que medida essas percepções irão influenciar a decisão em participar de um programa de Carona Solidària. 


\section{4 - MÉTODO}

\subsection{Tipo de Estudo}

Utilizou-se nesta pesquisa a metodologia quali-quantitativa para que os objetivos descritos anteriormente fossem alcançados.

Segundo MINAYO (2010, p.54), "o conhecimento científico se produz pela busca de articulação entre teoria e realidade empírica. O método tem uma função fundamental: tornar plausível a abordagem da realidade, a partir das perguntas feitas pelo investigador. No campo da saúde coletiva, os métodos frequentemente usados para estudos das populações humanas são os quantitativos (mais frequentes por meio da epidemiologia) e qualitativos (mais utilizados pelas ciências sociais). Ao se desenvolver uma proposta de investigação e no desenrolar das etapas de uma pesquisa, o investigador trabalha com o reconhecimento, a conveniência e a utilidade dos métodos disponíveis, em face do tipo de informações necessárias para se cumprirem os objetivos do trabalho".

Segundo a mesma autora, sobre a combinação de métodos, a antropologia, mesmo a funcionalista, tenta romper a barreira das explicações simplistas, criando abordagens mais complexas, como propõe Malinowski dizendo que é preciso: a) documentar estatisticamente, "mediante evidência concreta", tudo o que pode ser mensurado no "arcabouço da sociedade"; b) complementar os registros quantitativos pela observação da "maneira como determinados costumes, regras ou exceções são vividas no cotidiano pelos nativos pois esses são fenômenos sociológicos"; c) estar atento ao "corpo e sangue da vida real pois eles compõem o esqueleto das construções abstratas"; "compreender os imponderáveis da vida real"; d) ouvir e buscar compreender o "ponto de vista, as opiniões e as expressões dos nativos", isto é, ter em conta as maneiras típicas do pensar e sentir que correspondem às instituições e à cultura de uma comunidade (1975, p. 54-60) 
As abordagens qualitativas visam aprofundar um estudo, dentro de um contexto histórico e de uma dinâmica relacional hierárquica, entre pares ou com a população e compreender as representações e os sinais evasivos que não podem ser entendidos por meios formais.

De acordo com SEVERINO, (2010 p.119), a análise dos dados nas pesquisas experimentais e nos levantamentos é essencialmente quantitativa. Assim, a análise dos dados na pesquisa qualitativa passa a depender muito da capacidade e do estilo do pesquisador.

Quando se fala de pesquisa quantitativa ou qualitativa, e mesmo quando se fala de metodologia quantitativa ou qualitativa, apesar da liberdade de linguagem consagrada pelo uso acadêmico, não se está referindo a uma modalidade de metodologia em particular. Daí é preferível falar de abordagem quantitativa, de abordagem qualitativa, pois, com estas designações, cabe referir-se a conjuntos de metodologias, envolvendo, eventualmente, diversas referências epistemológicas (SEVERINO, 2010 p.119).

Segundo RICHARDSON et al (2012 p.87), o critério confiabilidade entre os métodos quantitativos e qualitativos é de suma importância. Esse critério indica a capacidade que deve ter os instrumentos utilizados de produzir medições constantes quando aplicados a um mesmo fenômeno. Como se manifesta a confiabilidade externa em ambos os métodos? No método qualitativo, existe relação muito próxima entre pesquisador e informante, o que possibilita informações detalhadas; as interferências são superficiais, descrevendo-se em detalhe o concreto; é comum o uso de gravador para registrar entrevistas e observações para análises posteriores.

Para o mesmo autor, no método quantitativo, as perguntas do questionário ou entrevista são formuladas clara e detalhadamente; mantém-se o anonimato do entrevistado para evitar distorção nas respostas; as definições são precisas e operacionalizam-se com indicadores específicos. Em ambos os métodos, o pesquisador deve classificar os conceitos utilizados e especificar as unidades de análise. 


\subsection{População de Estudo}

Todos os interessados em participar constituíram grupos indicados pela Instituição Hospitalar. Outros profissionais também especialistas na temática Poluição do Ar e Saúde Humana fizeram parte da população eleita para a realização da pesquisa, em sua segunda etapa.

\subsection{Os instrumentos utilizados}

O planejamento de uma pesquisa inclui um plano de execução e a elaboração dos instrumentos para serem utilizados na coleta de dados. Neste caso os instrumentos utilizados foram o questionário e a entrevista.

\subsubsection{O Questionário}

Foram entregues 256 questionários para os funcionários da Instituição Hospitalar (ICESP) de diferentes setores conforme cronograma e indicação do próprio hospital.

O questionário foi composto por 8 questões abertas e fechadas, algumas eram de múltipla escolha. (vide anexo VII).

Questionário é um conjunto de perguntas que o informante responde, sem necessidade da presença do pesquisador (ANDRADE, 2010, p.134)

Segundo SEVERINO (2010, p.125), o questionário é um conjunto de questões, sistematicamente articuladas, que se destinam a levantar informações escritas por parte dos sujeitos pesquisados, com vistas a conhecer a opinião dos mesmos sobre os assutos em estudo. As questões devem ser 
pertinentes ao objeto e claramente formuladas, de modo a serem bem compreendidas pelos sujeitos.

Para GIL (2010 p.121), o questionário é uma técnica de investigação composta por um conjunto de questões que submetidas a algumas pessoas tem o propósito de obter informações sobre seus conhecimentos, crenças, sentimentos, valores, interesses, expectativas, aspirações, temores, comportamento presente ou passado, entre outros.

Construir um questionário consiste basicamente em traduzir os objetivos da pesquisa em questões específicas. As respostas a essas questões é que irão proporcionar os dados requeridos para descrever as características da população pesquisada ou verificar a pertinência de hipóteses que foram construídas durante o planejamento da pesquisa.

Segundo HOFFMANN et al (2004, p.164), relatam o questionário como uma técnica construída a partir da definição de categorias ou itens que se quer avaliar, sobre os quais são feitas as perguntas ou proposições sobre o objeto do estudo. Distingue-se de entrevista, pois pode ser aplicado de forma a dispensar a relação pessoal (através da internet, correio, entre outros). Os questionários são estruturados normalmente na forma de enunciados acompanhados de uma escala que deve ser de fácil apreensão e preenchimento para os sujeitos e clara a qualquer examinador. Esta escala deve permitir precisar o desempenho ou a atitude do respondente, por meio de acordos ou desacordos parciais ou totais em relação a perguntas ou proposições (o tipo de escala mais utilizada é a de Likert).

A escala Likert ou escala de Likert é um tipo de escala de resposta psicométrica usada habitualmente em questionários, e é a escala mais usada em pesquisas de opinião. Ao responderem a um questionário baseado nesta escala, os perguntados especificam seu nível de concordância com uma afirmação (WIKIPÉDIA, 2012). 


\subsubsection{A Entrevista}

Foram realizadas entrevistas com profissionais da área da saúde, especialistas sobre a temática Poluição do Ar e Saúde Humana, docentes e pesquisadores da Faculdade de Saúde Pública (USP), da Faculdade de Medicina (USP), da Pontifícia Universidade Católica (PUC-SP) e Engenheiros de órgãos públicos ou privados indicados por meio da técnica do snowball descrita a seguir.

Esses profissionais responderam perguntas que foram elaboradas a partir de uma relação estruturada (vide anexo IX).

A entrevista estruturada desenvolve-se a partir de uma relação fixa de perguntas, cuja ordem e redação permanece invariável para todos os entrevistados, que geralmente são em grande número. Por possibilitar 0 tratamento quantitativo dos dados, este tipo de entrevista torna-se o mais adequado para o desenvolvimento de levantamentos sociais (GIL, 2010, p.113).

HOFFMANN et al (2004), diz que a entrevista é uma técnica de pesquisa largamente utilizada como forma direta de coleta de dados (o testemunho ou o depoimento do entrevistado é o meio pelo qual se torna viável o acesso ao objeto de estudo). A entrevista permite o contato direto entre o pesquisador e 0 entrevistado e por meio dela pode-se recolher informações pormenorizadas conforme os objetivos estabelecidos da pesquisa e o grau de estruturação dos seus quesitos.

Segundo GIL (2010, p.121), entrevista é a técnica em que o investigador se apresenta frente ao investigado e lhe formula perguntas, com o objetivo de obtenção dos dados que interessam à investigação. A entrevista é, portanto, uma forma de interação social. Mais especificamente, é uma forma de diálogo assimétrico, em que uma das partes busca coletar dados e a outra se apresenta como fonte de informação. 
RICHARDSON et al (2012, p.207), descreve a entrevista como sendo uma técnica importante que permite o desenvolvimento de uma estreita relação entre as pessoas. É um modo de comunicação no qual determinada informação é transmitida de uma pessoa $\mathbf{A}$ à uma pessoa $\mathbf{B}$.

Cada entrevista em profundidade proporciona um riquíssimo material de análise. O pesquisador, portando, deve estar preparado para passar um tempo considerável fazendo análise. Assim recomenda-se que, para uma pesquisa que utiliza entrevista com profundidade, não se entrevistem mais de 20 pessoas (RICHARDSON, et al 2012, p. 217-218).

\section{Técnica do Snowball ou bola de neve}

A técnica de coleta de dados para obter informações dos especialistas entrevistados sobre a temática Poluição do Ar e Saúde Humana foi a do snowball ou bola de neve.

Para coletar as informações necessárias, a pesquisadora entrou em contato com cada um dos profissionais indicados e assim agendou um horário individualmente nos seus respectivos locais de trabalho ou outro de sua preferência.

Segundo BALDIN e MUNHOZ (2011, p.332), os estudiosos espanhóis Velasco e Díaz de Rada (1997) definiam que a pesquisa de campo, em especial aquela aplicada em ambientes comunitários, como uma forma de investigação sociocultural que exige a utilização de um conjunto de procedimentos e normas que possibilitam a organização e a produção do conhecimento. Uma via para a execução desse trabalho de pesquisa em campo nas comunidades é a técnica metodológica snowball, também divulgada como snowball sampling (bola de neve). 
Essa técnica é uma forma de amostra não probabilística utilizada em pesquisas sociais onde os participantes iniciais de um estudo indicam novos participantes, que por sua vez indicam outros e assim sucessivamente, até que seja alcançado o objetivo proposto (o ponto de saturação).

O "ponto de saturação" é atingido quando os novos entrevistados passam a repetir os conteúdos já obtidos em entrevistas anteriores, sem acrescentar novas informações relevantes à pesquisa.

Dessa forma, a snowball (bola de neve) é uma técnica de amostragem que utiliza cadeias de referência, uma espécie de rede. A figura 4 mostra uma representação hipotética de uma cadeia de referências (p.334).

Figura 4 - Snowball sampling ou "Bola de Neve"

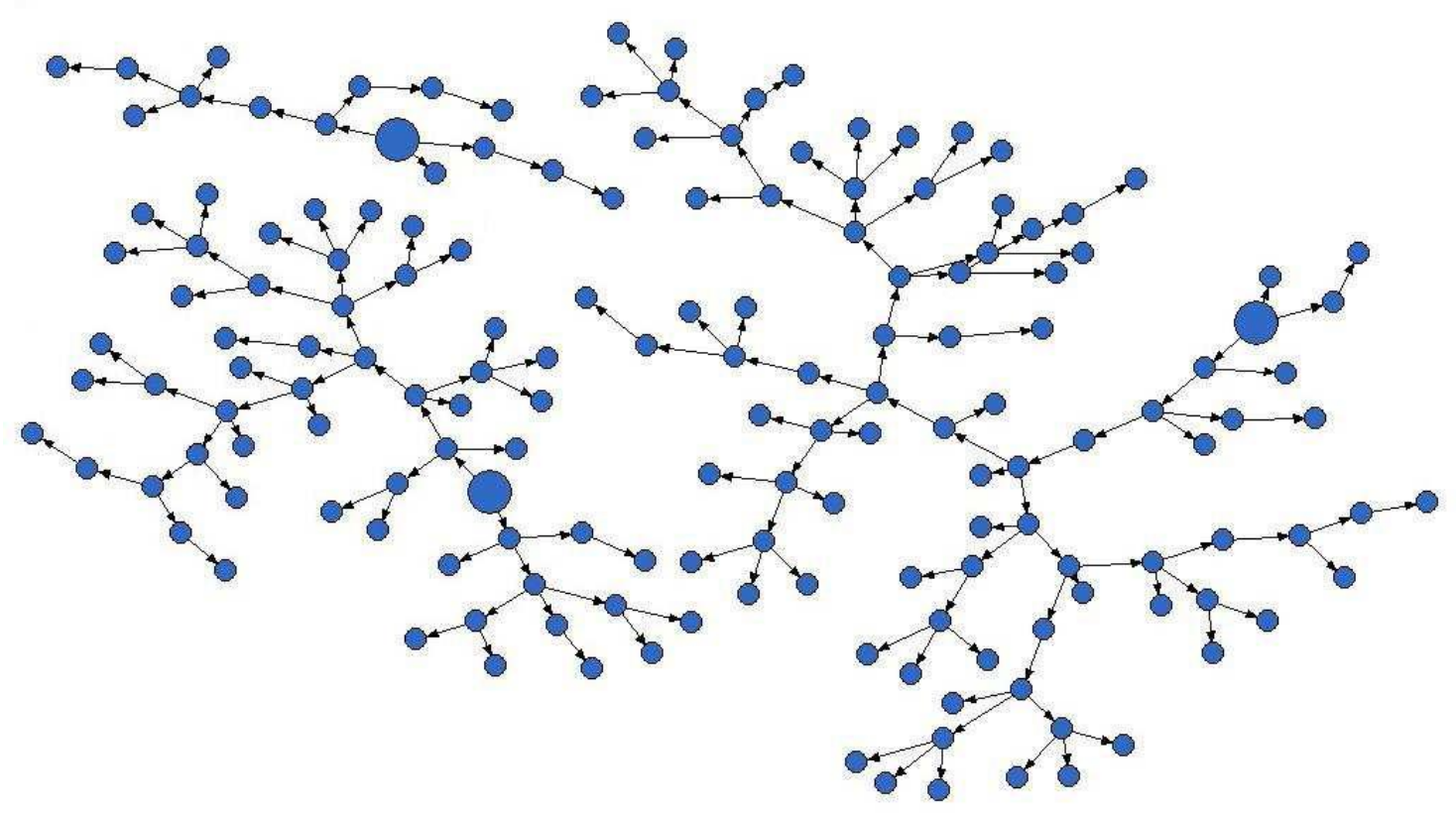

Extraído de: Albuquerque, 2009

- Primeiro entrevistado do grupo

- Participantes indicados 
Segundo ALBUQUERQUE, uma vantagem dos métodos que utilizam cadeias de referência é que, em uma população oculta, é mais fácil um membro da população conhecer outro membro do que os pesquisadores identificarem os mesmos. Além disso, a amostragem por bola-de-neve pode ser muito útil em pesquisas formativas, onde o objetivo é conhecer a população estudada e/ou testar os instrumentos que serão utilizados. Por outro lado, uma limitação se refere ao fato de que as pessoas acessadas pelo método são aquelas mais visíveis na população. Em se tratando de populações ocultas, as pessoas acessadas serão aquelas que assumem determinados comportamentos e atitudes que as tornam membros dessas populações. Deve ainda ser considerado que, visando assegurar a privacidade daqueles que realmente se escondem, algumas informações sobre as pessoas conhecidas podem ser, deliberada ou involuntariamente, suprimidas (2009).

\subsection{Coleta de dados}

\section{1를 Parte da Pesquisa}

Em 27 de Fevereiro de 2012 iniciou-se o pré-teste do questionário usando um roteiro semiestruturado. Este pré-teste foi realizado com pessoas de locais diferentes do espaço de estudo eleito, porém com características semelhantes.

ANDRADE (2010 p.131), salienta que o pré-teste consiste em aplicar os instrumentos da pesquisa em uma parcela da amostra a fim de verificar a validade ou relevância dos quesitos, a adequação do vocabulário empregado, o número e a ordem das perguntas formuladas, entre outros.

Para GIL (2010, p.134), depois de redigido o questionário, mas antes de ser aplicado definitivamente, deverá passar por uma prova preliminar. A finalidade desta prova, geralmente designada como pré-teste, é evidenciar possíveis falhas na redação do questionário, tais como: complexidade das questões, imprecisão na redação, desnecessidade das questões, constrangimentos ao informante, exaustão entre outros. 
O pré-teste de um instrumento de coleta de dados tem por objetivo assegurar-lhe validade e precisão. Como é sabido, no caso do questionário, a obtenção desses requisitos é bastante crítica.

Após realizado o pré-teste, algumas questões foram reajustadas para que se pudesse obter respostas mais claras e precisas.

Antes do início da investigação foram realizadas algumas reuniões com membros da Diretoria da Instituição Hospitalar, com a responsável pelo Setor de Humanização do Hospital, com esta pesquisadora e com a orientadora, para podermos definir estratégias de que maneira abordar os funcionários para participar da pesquisa.

Decidiu-se incluir todos que se dispusessem e pudessem participar da pesquisa.

A Instituição Hospitalar colocou a disposição para colaborar com a pesquisa uma funcionária, assistente social para fazer os contatos internos entre nossas demandas e os chefes de Setor do Hospital.

Foram enviados e-mails para todos esses chefes solicitando disponibilizar dia e horário para os funcionários participarem e explicar os motivos e objetivos da investigação para os mesmos.

Inicialmente, nossa intenção foi aplicar o questionário para os funcionários reunidos em grupo e em seguida fazer uma apresentação com ajuda do Power Point, informando sobre o projeto e oferecer algumas informações científicas, sobre a relação entre saúde e meio ambiente. Porém devido a fatores como falta de tempo, ou por não poderem se ausentar de suas funções (principalmente os funcionários dos setores assistenciais) tivemos que mudar essa estratégia inicial.

A estratégia seguinte foi entregar os questionários e os termos de consentimento livre esclarecido (Anexos VI e VII) diretamente aos chefes de setores que os distribuíam aos funcionários. O tempo estipulado para 0 devolvimento das respostas era dado de acordo com o setor aplicado.

Deste modo conseguimos aplicar o questionário e exibir o conteúdo do PowerPoint somente para 4 dos 16 grupos. Consideramos importante a participação desses 4 grupos pois assim que os questionários eram recolhidos, nos abordavam com perguntas e então suas dúvidas eram esclarecidas de imediato. Já com os demais grupos isso não foi possível. 
O período de realização da parte I da pesquisa foi de abril a setembro de 2012, tempo em que a pesquisadora ficou na Instituição aplicando os questionários e realizando pequenas palestras para esclarecimento dos grupos sobre $o$ assunto.

\section{2ªrte da Pesquisa}

Essa segunda parte da pesquisa foi importante devido a contratempos ocorridos na primeira parte. Acontece que no meio do processo de aplicação dos questionários circulou dentro da Instituição Hospitalar uma informação de que quem tomasse parte da Carona Solidária não receberia mais o valetransporte. Os participantes, mesmos os que inicialmente se mostraram interessados não transformaram a ideia em ação, isto é, não se habilitaram para usufruir da Carona Solidária. Optamos assim por realizar as entrevistas com profissionais especialistas em estudos da saúde e poluição do ar, para complementar nossa pesquisa.

Esses profissionais assinaram o termo de consentimento livre esclarecido (anexo VIII) para assim responderem as perguntas.

Neste estudo foi utilizado o método de Análise de Conteúdo, desenvolvido por BARDIN (2009).

Segundo RICHARDSON et al (2012 p.220), o interesse por interpretar textos é uma prática antiga. Já antes da Idade Média existiam pessoas interessadas em interpretar escritos sagrados ou políticos indubitavelmente sem o atual rigor científico. Em 1640 um trabalho feito na Suécia, pode ser considerado uma análise de conteúdo, e se referia a um estudo da autenticidade de 90 hinos religiosos e seus possíveis efeitos sobre os luteranos, tendo sido abordados além de temas religiosos, valores e manifestações favoráveis ou desfavoráveis (BARDIN, p.14).

Para os autores, a análise de conteúdo é um conjunto de instrumentos metodológicos cada dia mais aperfeiçoado que se aplica a discursos diversos.

BARDIN (2009 p.44), descreve a análise de conteúdo como sendo "um conjunto de técnicas de análise das comunicações visando obter, por procedimentos, sistemáticos e objetivos de descrição do conteúdo das 
mensagens, indicadores (quantitativos ou não) que permitam a inferência de conhecimentos relativos às condições de produção e recepção (variáveis inferidas) destas mensagens".

Pertencem, pois, ao domínio da análise de conteúdo, todas as iniciativas que, a partir de um conjunto de técnicas parciais mas complementares, consistam na explicitação e sistematização do conteúdo das mensagens e da expressão deste conteúdo, com o contributo de índices passíveis ou não de quantificação, a partir de um conjunto de técnicas, que embora parciais, são complementares. Para isso, deve-se seguir as três etapas descritas no método, isto é a pré-análise, a exploração do material e o tratamento dos resultados, a inferência e a interpretação (BARDIN, 2009, p.44).

A pré-análise é a fase de organização propriamente dita. Tem por objetivo a organização, embora ela própria seja composta por atividades não estruturadas, <<abertas>>, por oposição à exploração sistemática dos documentos. A primeira atividade e talvez a mais importante consiste em estabelecer contacto com os documentos a analisar e em conhecer o texto deixando-se invadir por impressões e orientações.

A fase de exploração do material é longa e trabalhosa e, consiste essencialmente de operações de codificação, decomposição ou enumeração, em função de regras previamente formuladas.

$\mathrm{Na}$ fase 3 os resultados em bruto são tratados de maneira a serem significativos (<<falantes $>>)$ e válidos. Dependendo do tipo de material, para um maior rigor dos resultados esses são submetidos a provas estatísticas, assim como a testes de validação. $O$ analista, tendo à sua disposição resultados significativos e fiéis, pode então propor inferências e adiantar interpretações a propósito dos objetivos previstos ou que digam respeito a outras descobertas inesperadas. (BARDIN, 2009, p.121-127).

BARDIN (2009 p.129), considera que tratar o material é codificá-lo. A codificação corresponde a uma transformação, que segue regras precisas dos dados brutos do texto. Esta transformação por recorte, agregação e enumeração, permite atingir uma representação do conteúdo ou da sua 
expressão, e pode esclarecer o analista acerca das características do texto, que podem servir de índices.

Dessa maneira procurou-se na análise dos dados de pesquisa seguir as etapas propostas pelo método.

\subsection{Aspectos éticos da pesquisa}

Foram cumpridas na pesquisa todas as exigências éticas fundamentais. Teve a homologação do Comitê de Ética em Pesquisa da Faculdade de Saúde Pública da Universidade de São Paulo (COEP-FSP/USP) por meio do OF.COEP/421/11, de 25 de novembro de 2011 e do Comitê de Ética em Pesquisa do Instituto do Câncer do Estado de São Paulo (ICESP) por meio do Memo ICESP-Pesquisa 1945/2011, de 7 de dezembro de 2011, bem como do Comitê de Ética em Pesquisa da Faculdade de Medicina da Universidade de São Paulo por meio de documento datado de 17 de Janeiro de 2012.

Anexamos também um adendo aprovado em 8 de Outubro de 2012 sob - OF.COEP/192/12, para que as entrevistas pudessem ser realizadas, conforme anexos (I, II, III, IV e V). 


\section{5 - RESULTADOS, ANÁLISE E DISCUSSÃO}

Este estudo, conforme apresentado na metodologia, foi dividido em duas etapas; a $1^{\underline{a}}$ e a $2^{\underline{a}}$ parte da pesquisa e as respectivas discussões dos dados obtidos serão apresentados a seguir:

\section{1ª Parte da Pesquisa - Análise de Questionários}

A seguir apresentam-se os resultados obtidos a partir da análise dos 256 questionários aplicados.

O meio ambiente é um importante determinante da saúde e da doença e nem sempre o ser humano contemporâneo tem se considerado parte deste meio, pois como afirma REIGOTA (2009 p.16), ele vive profundas dicotomias. Dificilmente se considera um elemento da natureza, mas um ser à parte, como um observador ou explorador dela.

Por isso ao se perguntar se havia ou não preocupação dos entrevistados em relação com o meio ambiente, todos disseram que sim, estavam muito preocupados com o meio ambiente. Por ser esta uma questão de múltipla escolha, quando se perguntou a causa da preocupação, dos 256, 185 deram as respostas apresentadas: 
A figura 5, exposta a seguir, mostra a frequência numérica das causas que preocupam os entrevistados em relação ao ambiente.

Figura 5 - Causas de preocupação com o Meio Ambiente pelos entrevistados na cidade de São Paulo no período de abril a setembro de 2012.



Nessa figura podemos observar a preocupação dos respondentes em relação aos fatores que ameaçam a sua qualidade de vida. Percebemos então que existe sim uma preocupação com os problemas ambientais causados pela poluição do ar “. A questão da sobrevivência veio em segundo lugar, com 34 respostas. Entre outras respostas interessantes destacaram-se também "a...preocupação com as futuras gerações e com o futuro dos filhos", Trinta e quatro pessoas não responderam essa questão. Surpreende a baixa frequência daqueles que reconhecem que a poluição faz mal à saúde. 
Outras respostas que se destacaram:

“...Acredito que devo cuidar do meio em que vivo, sei dos milhões de anos necessários para a formação da terra e da vida humana para contribuir em sua destruição. Nós somos as nossas ações. Sou a favor da vida”...

“...Eu me identifico com o meio ambiente e a natureza”...

“...O meio ambiente é nossa vida e será a continuidade do ser humano”...

“...Faço parte dele, visto haver uma relação constante entre o indivíduo e o meio ambiente em uma interação ação x consequência"...

“...Tudo o que acontece com ele (meio ambiente) reflete direta e/ou indiretamente em nossa volta, inclusive em nós mesmos"...

“...Somos inseridos no meio ambiente"...

“...Pelo simples fato de que o meio ambiente "sobrevive" sem nós, já o oposto não acontece".

Muitos dos respondentes conseguiram estabelecer a relação ambiente e saúde como pode-se perceber pelas respostas apresentadas. 
Entre os problemas ambientais mais importantes da cidade de São Paulo citados pelos respondentes, destacam-se os mostrados na figura 6 .

Figura 6 - Problemas Ambientais mais relevantes da cidade de São Paulo no período de abril a setembro de 2012.

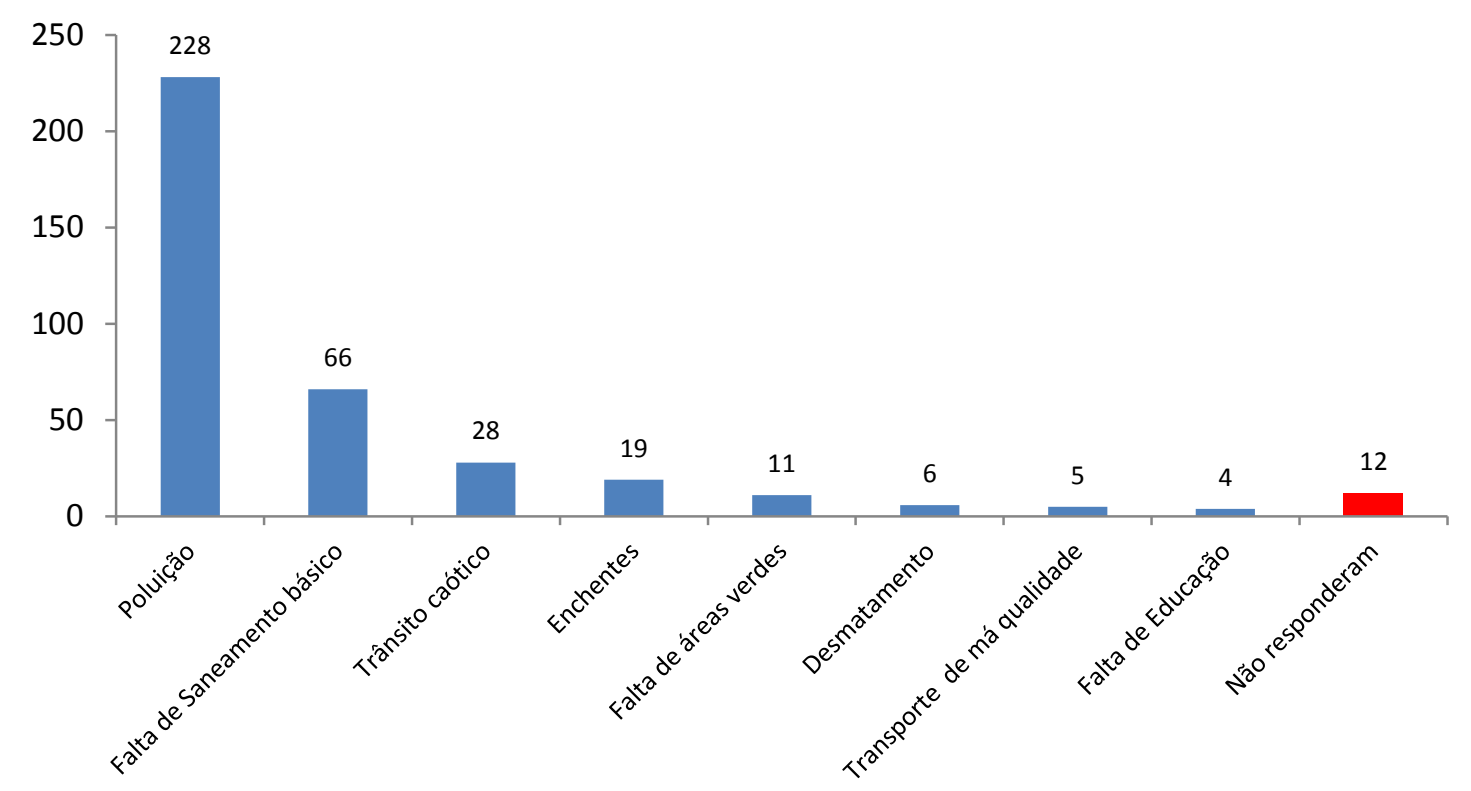

Pode-se verificar pela Figura 6 que o problema ambiental citado mais relevante da cidade de São Paulo atualmente, foi a poluição em geral aqui citada como poluição do ar, poluição do solo, poluição sonora e poluição visual.

A falta de saneamento básico (água tratada, coleta e tratamento de esgoto, coleta e disposição final de resíduos, drenagem de águas fluviais e limpeza urbana) foi considerada como problema por 66 respondentes, seguido pelo trânsito caótico que obteve 28 respostas. Cinco entrevistados citaram 0 transporte público de má qualidade e não menos importante foi a falta de educação indicada por apenas 4 pessoas. Doze entrevistados não responderam essa questão. 
Outras respostas foram dadas:

“...Para mim todos (os problemas) são preocupantes”...

“...O fluxo de veículos nas ruas é muito grande, deixando o trânsito muito lento e consequentemente eleva-se a poluição do ar, causando graves problemas de saúde à população”... 
A figura 7 mostra que apesar da maioria dos respondentes negar que tenham tido problemas de saúde relacionados a problemas ambientais, grande parte concordou que seus familiares tiveram.

Figura 7 - Problemas de saúde relacionados aos conflitos ambientais relatados pelos entrevistados na cidade de São Paulo no período de abril a setembro de 2012.

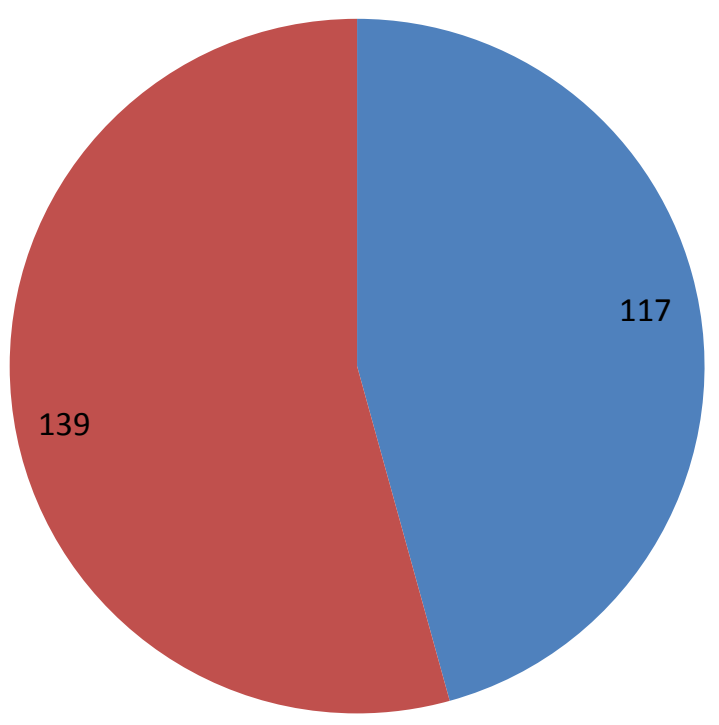

- Sim Não

Dos respondentes, conforme apresentado na figura 7, 117 disseram que sim. Os que responderam positivamente relataram que esses problemas ocorreram com familiares isto é, filhos, netos, sogro, cunhado, pai e avô. Cento e trinta e nove negaram ter tido problemas de saúde relacionados a problemas ambientais até o momento. 
A figura 8 apresentada adiante versa sobre doenças e sintomas percebidos pela população em relação aos seus familiares.

Figura 8 - Doenças e sintomas apresentados por familiares citados como decorrência da Poluição do Ar na cidade de São Paulo no período de abril a setembro de 2012.

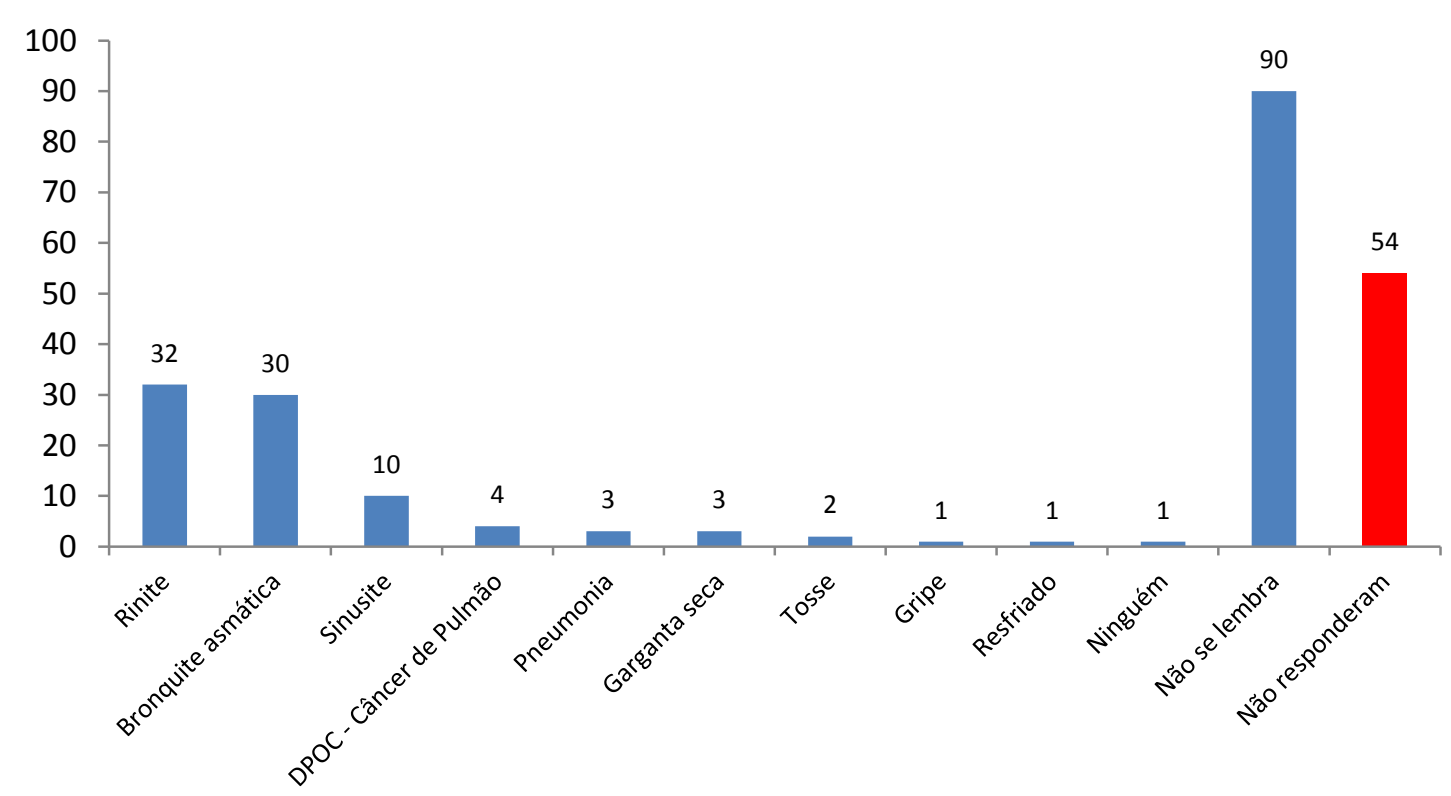

Embora a maioria não se lembrasse e 54 não tenham respondido, os 87 que responderam citaram doenças familiares e sintomas relacionados ao aparelho respiratório, com maior ou menor gravidade. Dessas doenças, a rinite foi a mais citada por 32 respondentes seguido da bronquite asmática e da sinusite. Porém cabe destacar que apesar da dificuldade das pessoas lembrarem algumas doenças causadas por problemas ambientais em São Paulo, a Doença Pulmonar Obstrutiva Crônica (DPOC) Câncer de Pulmão foi citado por apenas 4 respondentes, apesar de estarem trabalhando num hospital especializado no tratamento dessa doença. 
Um entrevistado citou ainda a "enxaqueca" e outro, "irritação nos olhos" como causado por problemas ambientais.

“...Outra resposta dada foi o agrotóxico o que demonstra o conhecimento de quem referiu que alguns produtos químicos fazem mal à saúde”... 
A maioria dos respondentes mostrou possuir conhecimento sobre a Carona Solidária, conforme pode-se verificar pela figura 9.

Figura 9 - Conhecimento sobre o transporte compartilhado ou Carona Solidária na cidade de São Paulo no período de abril a setembro de 2012.

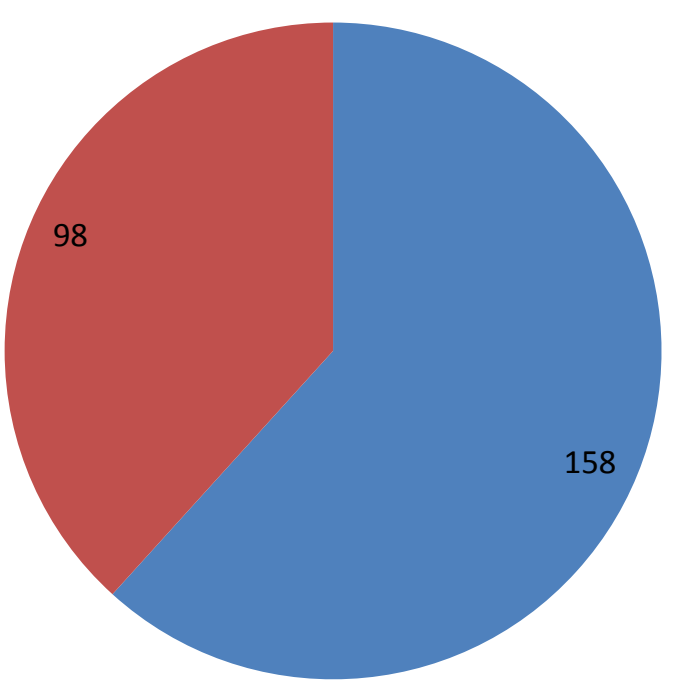

- Sim Não 
A seguir na figura 10 é mostrado o que os respondentes sabiam sobre a Carona Solidária.

Figura 10 - Conhecimento sobre o transporte compartilhado ou Carona Solidária na cidade de São Paulo no período de abril a setembro de 2012.

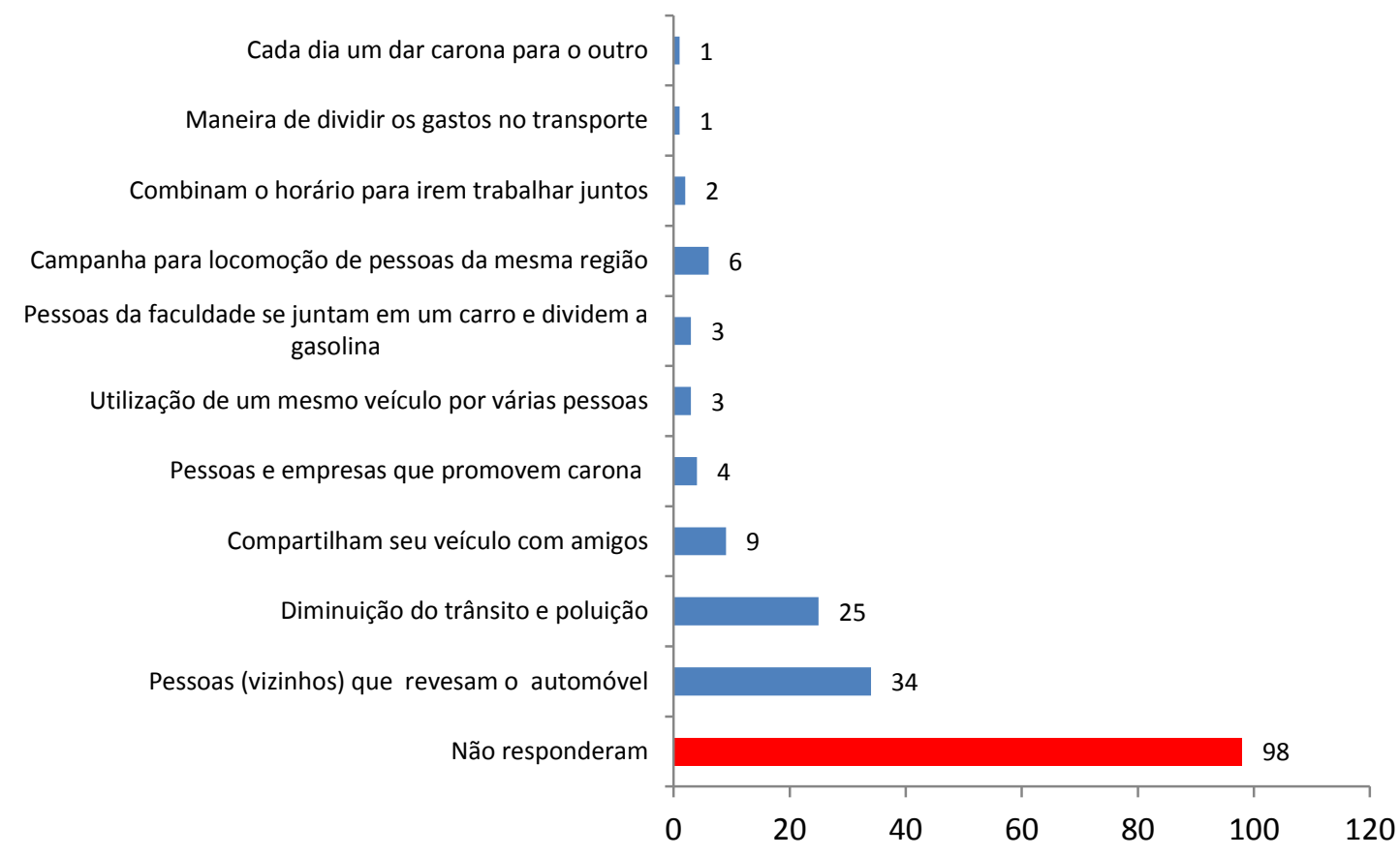

A figura 10 mostra que 88 respondentes dos que conheciam o assunto deram respostas diversas. Dentre eles 34 pessoas citaram a importância em praticar a Carona Solidária com pessoas conhecidas como seus vizinhos. Noventa e oito entrevistados não responderam essa questão. Outras respostas interessantes estão descritas a seguir:

“...Quando eu estava no Senai já se falava e praticava”...

“...Assisti uma apresentação sobre a carona no ICESP”...

“...Na Unicamp existe um programa semelhante”...

“...Ouvi falar sobre isso em um site no Jornal da Globo”... 
“...Existe um site no qual você pode se cadastrar para oferecer e receber carona de pessoas que trabalham no mesmo lugar ou próximos a você"...

“...Há um site em que as pessoas se cadastram para verificar se outra pessoa mora e trabalha perto de você para poder compartilhar o carro"...

“...Já ouvi no SPTV a opção de se cadastrar em um site e fazer parte de um programa onde se compartilha um veículo, diminuindo o número dos mesmos na cidade"...

“...Ouvi falar muito pouco, não como campanha, referente ao evento SWU$2010 " .$.

“...É um projeto da Prefeitura para diminuir o número de carros circulando na cidade"...

“...Vi propagandas na internet”...

"...Sim, há um site que cruza informações sobre endereço de trabalho e da residência e vê quem faz o mesmo trajeto para poder dar carona"... 
Tornou-se interessante conhecer a opinião dos profissionais de saúde do hospital sobre o transporte compartilhado conforme apresentado na figura 11.

Figura 11 - Opinião dos respondentes sobre o transporte compartilhado ou Carona Solidária na cidade de São Paulo no período de abril a setembro de 2012.

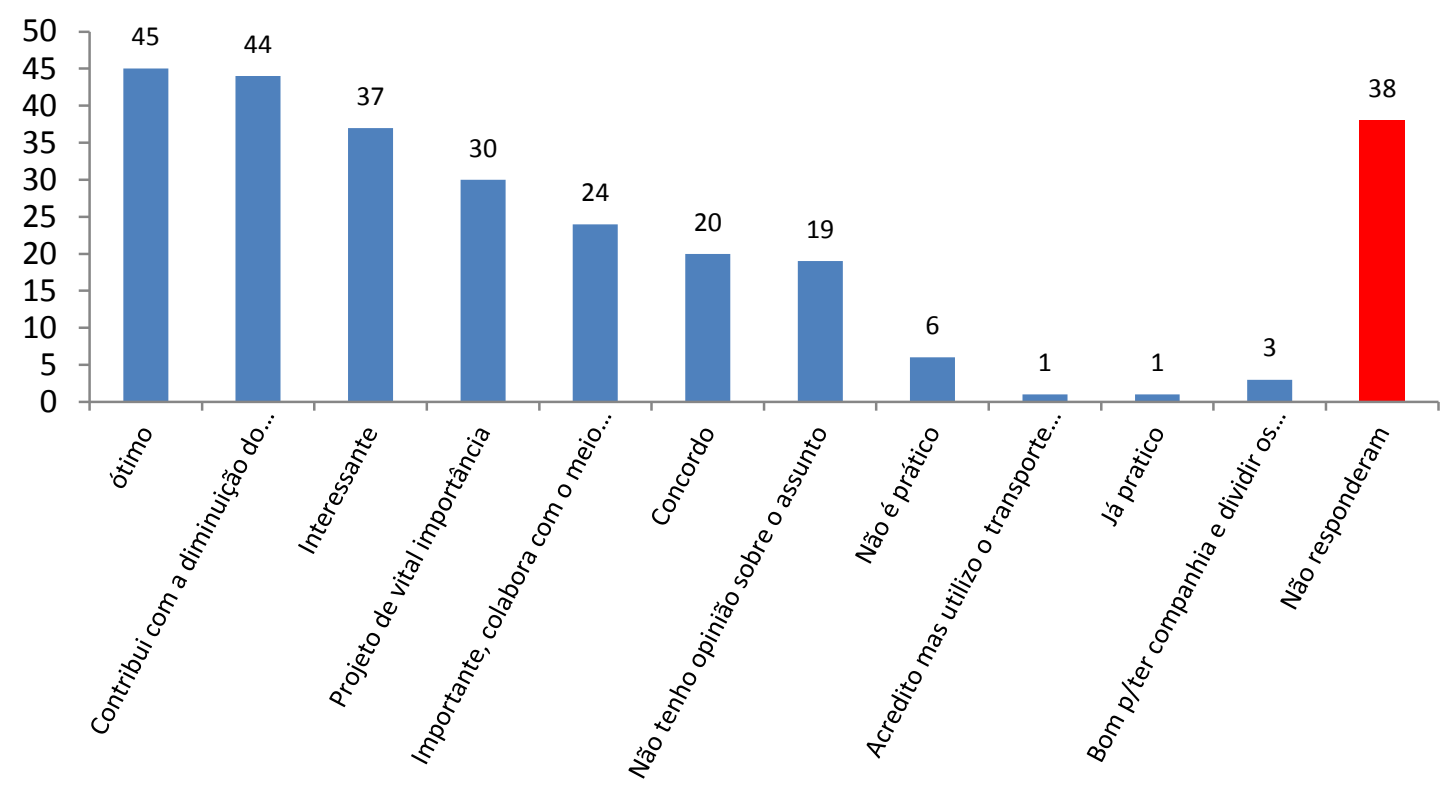

Apesar de parte dos entrevistados considerar importante compartilhar o transporte para ir ao trabalho, e que isso iria contribuir para a melhoria do ambiente e da qualidade de vida por exemplo, ninguém aderiu à proposta colocada pela pesquisadora de participar do projeto em atendimento a demanda do hospital

Outras respostas tiveram destaque conforme relatado abaixo:

"...Acredito que o projeto venha ajudar muitas pessoas que usam o transporte público, mas para os colaboradores do Intituto do Câncer do Estado de São 
Paulo (ICESP) não haverá muita diferença, são pouquíssimos os que vem de carro"...

“...Acho uma proposta muito válida e pode dar certo em vários locais, porém no ICESP a grande maioria vem de transporte público, pois nas redondezas não tem lugar para estacionar e os estacionamentos são caros demais"...

“...A Carona Solidária é uma boa alternativa, já utilizada em várias empresas, condomínios e vizinhos, como alternativa ao transporte coletivo insuficiente ou precário em alguns lugares. Permite a redução de carros em circulação com apenas um único passageiro. Essa opção também colabora com a redução de emissão de gazes com efeito estufa"...

"...Se todos que têm carro dessem carona seria bom, mas é muito complicado"...

"...Quanto mais pessoas tomarem essa iniciativa será melhor para todos e para o planeta"...

“...Eu não vou discutir porque não tenho carro”...

"...Acho válido e ao mesmo tempo contraditório. Se utilizo este sistema com quem já trabalha de carro, não vejo problemas. Entretanto posso estimular que alguém que utilizava transporte público, retire o automóvel da garagem já que 0 custo ficaria menor"...

“...O projeto é bárbaro porém, precisamos trabalhar muito em cima pois envolve educação, cultura. As pessoas precisam antes de mais nada querer respeitar o meio ambiente e se preocupar com ele"...

"...Importante para todos. As multas deviam ser dadas a quem dirige sozinho"...

“...Para mim a Carona Solidária não é novo, pratico há mais de 10 anos. Auxilia na questão do transporte coletivo, solidariedade, otimização e redução de tempo, novas amizades"...

"...Penso que todas as alternativas para tentar resolver ou minimizar este problema sejam válidas e passíveis de acordos"... 
“...Acho importante a divulgação no entanto, vejo que existem pessoas que não se preocupam com o assunto"...

“...Seria legal se existisse realmente, mas no mundo em que vivemos as pessoas são muito individualistas e não pensam no bem-estar de outras pessoas ou se estão poluindo o meio ambiente com o escapamento de seus carros"...

“...É muito difícil ter opinião pois sempre tem um contra. O transporte público ou carro? Fica muito difícil”...

“...Acho bem interessante pois vivemos numa cidade com número grande de pessoas, onde a maioria utiliza os carros para irem trabalhar e daqui alguns anos São Paulo não irá comportar alias, não é só esse problema, a poluição que esses carros geram. Na verdade acho que deveriam melhorar o transporte público para que as pessoas parem de usar o carro e utilize um transporte público digno"...

“...Importante, porém em São Paulo acho difícil de ser implantado visto que muitas pessoas moram em lugares distantes do local de serviço fazendo com que optem pelo transporte público devido aos custos e tempo gasto no percurso (trânsito) "...

“...É um assunto importante, mas, receio de que a responsabilidade tem que ser o fator mais importante por ter um grupo de pessoas e um dependendo do outro".

“...Acho importante para empresas que não são atendidas pelo transporte público. No caso do ICESP, acho desnecessário”...

“...É positiva com relação a diminuição de emissão de poluentes. No entanto, é negativa com relação à segurança do colaborador (em termos de confiança naquele que dá carona, cumprimento de horários e com relação à segurança em caso de acidente de trabalho). Acredito que o problema principal é com relação ao transporte público. Maior acesso, melhores condições de vias, de opção de transporte, seria a melhor solução envolvida no assunto"... 
Dos 256 respondentes, 233 nunca haviam se cadastrado em nenhum site. Dos restantes 22 deram respostas não pertinentes. Somente 1 pessoa disse ter se cadastrado em site de carona, anteriormente. A figura 12 explora esse tema.

Figura 12 - Razões de ausência de cadastro anterior em site de carona na cidade de São Paulo no período de abril a setembro de 2012.



Como pode-se observar na figura 12, diversos são os motivos para a falta de cadastramento em site de Carona Solidária. Ao contrário do que se esperava nas respostas, somente 12 pessoas disseram não ter se cadastrado por insegurança e medo. Isso mostra mais uma vez que os motivos são outros como "...desconhecimento do projeto" onde tivemos 103 respostas. Os 73 respondentes deram respostas variadas, apesar de 57 não terem respondido. 
Com relação a indicação do site para outras pessoas, ninguém se manifestou, como mostra a figura 13.

Figura 13 - Opiniões sobre o site de carona para adesão de outras pessoas* na cidade de São Paulo no período de abril a setembro de 2012.

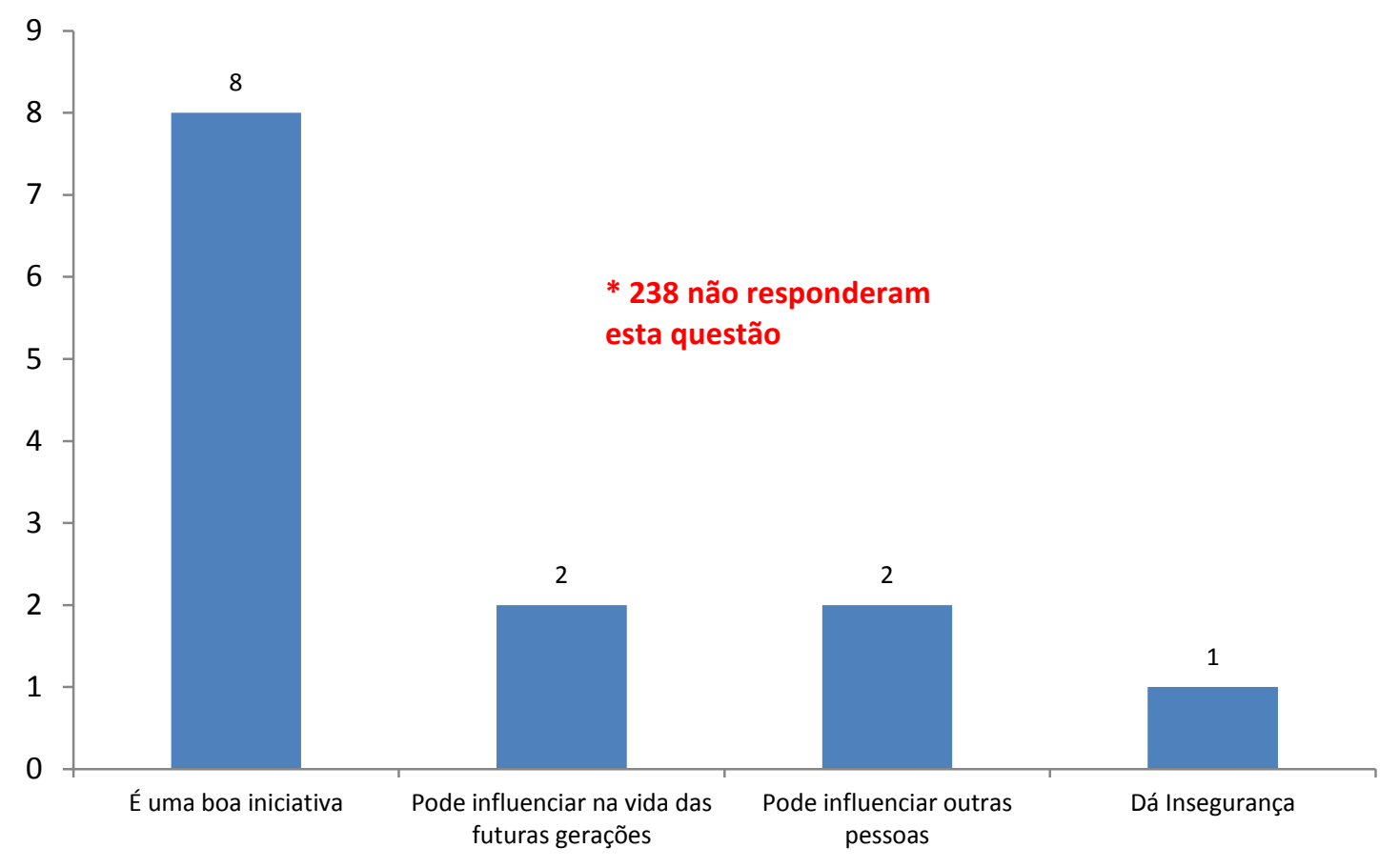

Embora ninguém tenha se cadastrado no site Carona Solidária como proposto, treze pessoas se manifestaram favoráveis ao cadastramento pelos motivos identificados na figura acima. 
A figura 14, a seguir, mostra conflitos associados a segurança dos participantes.

Figura 14 - Fatores relacionados à segurança dos participantes de um programa de Carona Solidária na cidade de São Paulo no período de abril a setembro de 2012.



Por ser uma questão de múltipla escolha, houve um total de 263 respostas, conforme apresentado na figura 14.

A maioria dos entrevistados considerou importante conhecer e confiar nos participantes de um programa de Carona Solidária, apesar de 54 pessoas não terem respondido a esta questão,

Sabendo que a insegurança e o medo fazem parte da vida das pessoas, apenas 21 respondentes acharam este fator determinante. Outras respostas, como veículos em boas condições de uso também pareceram importantes para esses entrevistados. Entre outras respostas interessantes apareceu a questão 
do cadastro que deve ser criteriosamente controlado e que foi citado por apenas 7 respondentes.

“...Deve haver segurança para o carona, caso haja acidente no trajeto, pode utilizar os meios cabíveis para tal, o que atualmente não é possível”...

“...O seguro em caso de acidente de trajeto deve existir (de modo), que saibamos quem está no sistema de carona que for usar"...

“...A questão da confiança é complicada. Você apenas tem que confiar na pessoa que te der carona e tem que passar confiança para os outros "tomarem carona com você". Mas é preciso ir além! Já existe a tecnologia, carros elétricos... O rendimento do motor de um carro elétrico passa dos 95\% enquanto o de um à combustão não chega a 30\%! Então, por causa de interesses maiores nós ainda continuamos "queimando petróleo". Conclusão dos $R \$ 2,50$ que você paga na gasolina, aproximadamente, $R \$ 1,75$ é para aquecer o ambiente"...

“...O programa deveria ser do Governo. Assim todos os cadastrados usariam seu perfil com todos os dados validados pelo Governo e Polícia”... 
A figura 15 mostra os dados relativos à proprietários de veículos.

Figura 15 - Em relação a possuir ou não automóvel na cidade de São Paulo no período de abril a setembro de 2012.

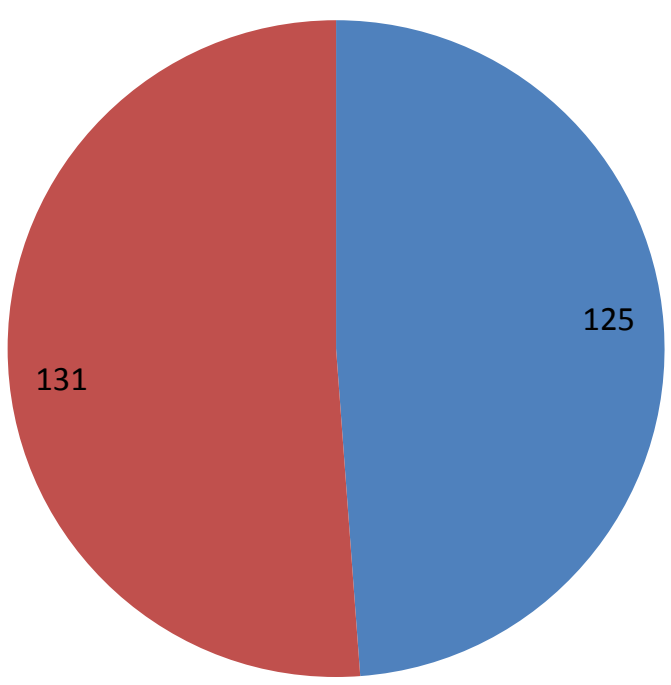

- Sim Não

A maioria afirmou não possuir carro. Alguns dos entrevistados que disseram não justificaram suas respostas "...não tenho carro pois utilizo o transporte público", ou "...que moravam próximo ao local de trabalho". Mas o que chamou a atenção na análise dos questionários é que aqueles que disseram não ter carro se mostraram mais dispostos a praticar a Carona Solidária. 


\section{2ª Parte da Pesquisa - Resultados das Entrevistas}

A seguir são enumerados os conteúdos de interesse extraídos das entrevistas, segundo categorização em temas de acordo com BARDIN (2009).

Tema 1 "Percepção sobre a relação meio ambiente (poluição do ar) e o binómio saúde-doença”.

A maioria achava que a população em geral consegue perceber esta ligação, conforme pode-se notar nos depoimentos a seguir:

\section{Entrevistado 1}

“... Existe uma percepção muito grande da população de São Paulo, hoje ela está muito mais ciente de que a poluição é um problema e essa poluição pode fazer mal a gente".

\section{Entrevistado 2}

“... Hoje a população já tem certo esclarecimento sobre isso. Eu acho que pela própria divulgação da imprensa, pelo menos em linhas gerais. Eles conseguem relacionar não com profundidade lógica, mas conseguem saber, por exemplo, que a poluição do ar faz mal à saúde, normalmente mais ao aparelho respiratório".

\section{Entrevistado 3}

“...Eu acho que a associação em geral que as pessoas fazem dos problemas de saúde relacionados com a poluição do ar são pequenos: problemas irritação do nariz, coisas assim (que trazem) um certo desconforto mas, eu acho que eles não têm noção que existem problemas sérios de saúde associados à poluição do ar". 


\section{Entrevistado 4}

"... A população em geral eu acredito que não, quando se vê a questão do lixo, eu acho que é uma coisa mais palpável, quer dizer: um ambiente não limpo, terrenos baldios com lixo acumulando, agora... a poluição do ar, para uma parte das pessoas, eu acho que não chama a atenção que aquilo pode estar relacionado à problemas respiratórios".

\section{Entrevistado 5}

"... De maneira geral sim, por uma série de fatores quando os filhos adoecem sempre falam da poluição, a poeira que entra nas casas...

\section{Entrevistado 6}

“... Eu acho que sim, na cidade de São Paulo sim, em algumas outras regiões do Brasil, menos. O tema poluição do ar e saúde (é mais conhecido). Se a gente for perguntar hoje quais são os problemas mais importantes na cidade, vai aparecer: violência, mobilidade e poluição entre os 10 tópicos que mais preocupam as pessoas do ponto de vista da dinâmica da cidade então, o problema não está relacionado à falta de percepção. Mas à falta de uma política integrada que permita que as atitudes que poderiam reduzir a poluição sejam efetivamente implementadas".

\section{Entrevistado 7}

"...De certa forma eu acho que sim, porque isso tem sido bastante divulgado nos meios de comunicação, nos noticiários. Agora eu já li a respeito que as pessoas ao contrário do que eu penso, não sabem, não se ligam. Elas assistem o noticiário, mas elas não prestam a atenção, elas não identificam muito o problema".

\section{Entrevistado 8}

"...A população percebe mas tem dificuldade em assumir a sua parte. Especialmente nos automóveis, o meu carro não polui, o que polui é o seu e a poluição do meu carro eu não vejo. O (meu) escapamento está atrás, eu vejo o seu que está na minha frente, isso é o que está na cabeça das pessoas. 
Quando a gente começou a falar de poluição do ar, o grande problema visível e fácil de tratar era a fumaça, a fumaça do ônibus, a fumaça do caminhão. O dono do veículo sempre achava que a fumaça não era do veículo dele quando levava na oficina. A gente tinha que aceitar um pouco isso porque a gente pegava carro novo, ele não era feito para não ter fumaça, ninguém exigia".

\section{Entrevistado 9}

"...Existe uma população mais informada pelo jornal, que assiste aos noticiários, que está em contato com as questões da cidade. Existem jornais que têm até páginas específicas sobre a cidade. Eu acho que essas pessoas conseguem sim, fazer a relação. Para mim, a população não é uma massa, depende do nível de inserção nessas questões. As questões ambientais vêm gradativamente sendo inseridas no cotidiano das pessoas. Na questão do carro: olha se eu deixar de andar de carro, se eu tiver um programa de carona vai ser melhor para mim, eu vou economizar mais. Eu acho que a questão monetária, a questão financeira é mais visível. As questões ambientais de relação de variáveis que uma leva a outra e em que isso pode refletir, eu acho que são mais difíceis do público em geral perceber. As pessoas precisam se apropriar mais de tudo e melhorar o seu padrão de reflexão. Não é só informar, educação não é só informação, é mudança de comportamento. Você pergunta ele entende, (mas) para mudar comportamento, eu acho que a maioria não (está preparada)".

\section{Entrevistado 10}

“...Eu acredito que sim, nas últimas décadas o tema poluição do ar e saúde tem sido bastante recorrente na mídia. Por ação direta de alguns pesquisadores envolvidos que fazem questão de fazer esta transferência de informação para a população em geral e também pela compreensão por parte da mídia de que esse é um tema relevante, principalmente numa cidade como São Paulo. Isso tem se tornado uma discussão cada vez mais presente, mesmo nas palestras que a gente faz em toda a cidade, nas escolas, etc. Você percebe por parte dos alunos e dos país dos alunos uma conscientização de que isso é um problema que faz parte da rotina e que eles precisam se inteirar para poder tentar solucionar". 


\section{Entrevistado 11}

"...Eu acho que sim, principalmente em relação à poluição do ar. Tem outras questões ambientais para as quais a população ainda não está desperta, mas para a poluição do ar, eu tenho a impressão que sim. (Não é só) impressão não, a gente tem feito pesquisas aqui em relação à ruídos urbanos e lá no questionário tem uma questão perguntando que problemas ambientais em relação ao ambiente que ela colocaria, e em ordem de prioridade. A poluição do ar está sempre em primeiro lugar, eu acho que isso é por conta de que já tem até uma tradição de pesquisa nesta área aqui no nosso meio em São Paulo. Isso tem saído na mídia, então as pessoas vão incorporando".

\section{Entrevistado 12}

“...Eu acho que a questão da percepção, dá margem para muita discussão, porque de fato para alguns problemas mais complicados e mais longe das questões que são reais determinantes da qualidade de vida ou questões mais emergenciais dependendo da camada da estratificação social, você vai ter uma percepção diferenciada. As camadas mais humildes da população tem uma preocupação com coisas mais imediatas, mais próximas do domicilio: saneamento, o problema do transporte coletivo. Então, essencialmente, eles não tem uma percepção muito boa para os problemas da poluição atmosférica. O Saldiva trabalha com isso, ele tem as afirmativas de que morar em São Paulo significa fumar alguns cigarros por dia, eu não me lembro de quanto, (acho que) são 4 cigarros por dia. Eu não acredito que toda a sociedade tenha uma real percepção disso. Uma pessoa cosmopolita que quer viver em São Paulo, ela pode até perceber, mas acha tão bacana ou tão interessante viver em uma cidade como São Paulo que isso acaba não interferindo na percepção do problema e ela paga isso com relação às vantagens que ela julga ter. É margem para muita discussão. Eu acho que pesquisas específicas com relação à percepção deveriam ser realizadas, até porque o potencial de uma pesquisa qualitativa em explicar a maneira como isso ocorre na sociedade é de grande importância na determinação de como a sociedade vai aderir ou requerer políticas que venham mitigar a poluição atmosférica". 


\section{Entrevistado 13}

"...Eu acho que a população tem uma percepção do que seja poluição (como) por exemplo, a fumaça do caminhão, do ônibus, essa é a percepção. Ela não tem como associar as doenças relacionadas à poluição que são crônicas ou exacerbação em quem tem doença aguda. Ela não liga aquela doença à manifestação delas. Tem um senso comum que a poluição faz mal, mas ela não liga muito às doenças, especificamente".

\section{Entrevistado 14}

"...Eu acho que sim, eles relacionam alguns sintomas com episódios da poluição próximos a grandes vias, eu acho que existe essa relação. Mais recentemente até para divulgação de mais estudos pela vida dá para encarar a percepção da população em relação aos problemas da poluição".

\section{Comentários}

JACOBI (1999, p.141-156), em pesquisa realizada no mesmo ano, verificou que $82 \%$ (oitenta e dois por cento) da população consideravam a poluição do ar como o maior problema ambiental da cidade de São Paulo. O tipo de poluição do ar mais mencionado estava vinculado à poeira e emissão veicular.

O autor afirmou também que as consequências da poluição do ar são percebidas como um conjunto de aspectos relacionados com a saúde, embora de maneira muito superficial, isto é relacionando (muito mais) a poluição aos inconvenientes (por exemplo) de uma casa ficar suja.

Quando consultados sobre a sua percepção em relação à qualidade do ar na região e na cidade como um todo, a maioria dos moradores entrevistados consideraram que o problema era mais sério na cidade do que nos bairros.

JACOBI relatou ainda que um dos aspectos que mais chamou sua atenção na análise dos resultados referentes à pesquisa feita no ano de 1999 estava relacionado à ambiguidade em torno da compreensão da noção de interesse geral, tema fundamental no debate da questão ambiental (p.165). 
Os dados mostraram que a maioria da população estava ciente das soluções e possibilidades existentes para atenuar os impactos negativos decorrentes da degradação ambiental. Embora exista esta percepção dos problemas ambientais, observa-se que geralmente, os moradores aceitam a convivência com estes agravos assumindo frequentemente uma atitude passiva em face da existência do problema.

Para JACOBI (1999, p.165), os resultados observados em sua pesquisa permitiram formular indicadores qualitativos que representaram a possibilidade de uma compreensão aprofundada a respeito das percepções e práticas dos moradores da cidade de São Paulo - suas ambiguidades e contradições.

O autor concluiu dizendo que isso significa, portanto, a possibilidade de um conhecimento aprofundado da cadeia de relações entre o que a população pode ou não identificar como sendo problema ambiental, o que eles detectam como fonte e causa dos problemas e o que direciona suas atitudes e possíveis soluções.

Para BECK (2011, p.54), tudo isso acontece porque o visível incorre nas sombras de ameaças invisíveis. Aquilo que escapa à percepção já não coincide com o irreal, podendo chegar mesmo a possuir um grau elevado de concretude em termos de ameaça. O mundo da carência ou fartura visíveis ensombrece-se sob o peso da superioridade de forças dos riscos.

Ou seja a evidência da carência ofusca a percepção dos riscos; mas, em compensação, apenas sua percepção, e não sua concretude e eficácia: riscos denegados prosperam particularmente bem e rápido (BECK, 2011, p.54).

Os entrevistados deixaram claro na maioria das falas que acreditam que a população em geral tem percepção dos problemas de saúde relacionados aos problemas ambientais nesse caso pela poluição do ar, porém de uma maneira mais tímida em relação àquelas doenças mais graves. 
Atualmente a poluição do ar tem sido sentida também por moradores de alguns bairros da cidade de São Paulo fato que não acontecia anteriormente.

A má distribuição de empregos e moradia também contribui para o número de veículos nas ruas que por si só formam os congestionamentos, haja visto que as pessoas passaram a residir longe de seu local de trabalho.

Por isso os motoristas procuram caminhos alternativos para fazer seus percursos, desviando seus trajetos para os bairros e arredores da cidade.

Esses caminhos alternativos como ruas mais próximas dos centros urbanos facilitam (trabalhadores, estudantes entre outros) a chegarem um pouco mais rápido ao seu destino, mas em compensação acabam levando a poluição do ar para perto dos moradores desses bairros.

O lugar onde se mora e as facilidades que os grandes centros oferecem tornam as populações reféns.

Sendo assim os riscos incluindo os ambientais acabam passando desapercebidos para os moradores que muitas das vezes não possuem carros e não necessitam de utilizar transporte público para se locomover uma vez que podem encontrar tudo aquilo que precisam próximo de sua moradia (BECK, 2011). 


\section{Tema 2) Benefícios do Programa de Carona Solidária}

\section{Entrevistado 1}

“...Primeiro acho que tem o aspecto da socialização. A segunda coisa você está de uma maneira ou de outra contribuindo para melhorar a qualidade do ar na cidade e todo mundo se beneficia, inclusive, quem está participando".

\section{Entrevistado 2}

“...A primeira coisa é deixar o carro em casa. Deixar o carro em casa significa diminuir despesa (como) combustível. Tem também a questão do relacionamento, ao invés de fazer uma viagem sozinho faz-se uma viagem com várias pessoas. Lembrei de que em um carro com 4 pessoas, o risco da violência urbana é menor pois, ao se abordar alguém sempre se prefere quem está só".

\section{Entrevistado 3}

“...Em primeiro lugar a criação de uma consciência de que todo mundo precisa fazer alguma coisa para que a gente tenha uma melhora importante nessas mudanças. A mudança de atitude, a conscientização de que eu posso deixar o meu carro em casa e o compromisso de cidadão responsável também pela qualidade do ar, é um benefício muito importante.

\section{Entrevistado 4}

“...(Traz) inúmeros benefícios a questão do meio ambiente e da poluição atmosférica é um deles, (além da) questão da solidariedade no trânsito, solidariedade que deveria existir mesmo que não tivesse a Carona Solidária. Com a Carona Solidária as pessoas compartilham locomoções, que dizer, deslocamentos de um lugar para o outro. ...Muitas pessoas moram em prédios de apartamentos, ali é uma comunidade, não è? Estão compartilhando já a residência, os espaços comuns da residência. ...A carona, eu tenho a impressão que ajuda no meio ambiente, desenvolve amizades, é o trânsito compartilhado, economia nos gastos e deixa uma fluidez maior no trânsito". 


\section{Entrevistado 5}

"...Eu acho que tem benefícios de ordem financeira: economizar combustível, estacionamento, desenvolver um companheirismo entre as pessoas, com solidariedade, isso é muito importante nos dias de hoje. Em termos ambientais é óbvio que a diminuição de carros nas ruas também facilita bastante a mobilidade no trânsito e (traz) como consequência a diminuição da poluição também".

\section{Entrevistado 6}

“...Primeiro, uma economia de combustível o que é óbvio, segundo, tem vários estudos mostrando que relacionamento social melhora a saúde, então se você tiver a chance de mostrar isso, fazer uma rede social, isso ajuda ... As empresas poderiam (oferecer) benefícios para as pessoas. Por exemplo, se você conseguisse colocar 3 pessoas num carro, ela (empresa) gastaria menos e poderia oferecer uma parte disso em aumento ou benefício ou bônus para os funcionários, acho que isso é legal".

\section{Entrevistado 7}

"...O conforto de um dia você dirigir e outro dia você colocar cinco pessoas no carro, você dirigir uma vez por semana, é um conforto. Um dia você dirige mas, nos outros quatro, os outros amigos (que vão dirigir para você). O principal para o meio ambiente seria bom e em segundo lugar, haveria conforto".

\section{Entrevistado 8}

"...Os benefícios são muitos, primeiro divide a poluição e a emissão por 3, com três pessoas no mesmo carro, isso já é um grande benefício. Segundo: divide o custo por 3 , eles podem ratear o custo do combustível e terceiro, divide 0 stress por 3. Se você melhorar a velocidade média do tráfego, se você passar de 19 para $30 \mathrm{~km} / \mathrm{h}$, você corta a emissão do carro pela metade. Quando o pessoal que anda de carro começou a ver que o ônibus andava mais depressa migrou para o ônibus e aí melhorou a velocidade dos carros, então, foi exatamente isso: diminuiu o número de carros, melhorou a velocidade dos carros e levou um monte de gente para o ônibus". 


\section{Entrevistado 9}

"...No primeiro momento o que eles mais percebem, eu acho que é a questão da economia de recursos. Você ter a carona permanente é muito mais confortável. Outros benefícios: o conforto (pois) vai de porta-a-porta e você não precisa tomar um trem ou ônibus para chegar até lá. Poder ir em conjunto com outras pessoas; ir bem mais confortável ouvindo música, dentro do carro sem risco de assalto; mas o principal é (que é) bom para mim porque eu vou economizar"...

\section{Entrevistado 10}

“...Teoricamente ele melhora o relacionamento das pessoas, você cria um grupo de colegas que passa a conviver, que passa a compartilhar esse transporte. Dentro daquele grupo que tem um deslocamento prioritário e único para o seu local de trabalho; que passa nesse trabalho todo o seu dia; eu acho que para esse grupo essa iniciativa seria bastante interessante".

\section{Entrevistado 11}

"...Muitos benefícios: começando pela economia e quando mexe no bolso as pessoas sempre acham que é bom; é uma possibilidade para você ter mais contato com as pessoas, estreitar os laços de amizade, pois você vai estar compartilhando um tempo com uma outra pessoa. (Ao) diminuir o trânsito, sem dúvida você diminui a poluição, o ruído, "o stress", várias coisas que são consequências do trânsito".

\section{Entrevistado 12}

“...Traria um benefício geral para a sociedade; reduzindo todo o tempo perdido na locomoção de uma pessoa por carro, uma pessoa um carro; redução no tempo de deslocamento; redução nos riscos de acidentes de trânsito certamente e ainda a redução da poluição atmosférica dado que a matriz que prevalece ainda pelas próximas décadas é o automóvel movido a combustíveis fósseis, entre outros". 


\section{Entrevistado 13}

"...Redução de custos, se isso tiver expressão numérica vai contribuir para a redução da poluição sonora e do ar. Beneficia não só os adeptos mas outras pessoas, inclusive os não adeptos"...

\section{Entrevistado 14}

"...Eu acho que do ponto de vista individual você trabalhar eu acho assim. Entrar dentro de um programa como esse você pode otimizar os recursos do carro dividindo, ocupando este espaço interno com mais pessoas".

\section{Comentários}

A Carona Solidária tem inúmeras vantagens conforme opinião da maioria dos entrevistados, mas para que essa prática seja incorporada pelas pessoas, leva um certo tempo. Tudo o que é novo é difícil de ser aceito de imediato, pois envolve questões culturais, mudança de hábitos e uma nova postura para se adequar ao novo comportamento. Um dos entrevistados citou que já existem pesquisas que mostram que quando as pessoas estão em contato por mais tempo com outras, tendem a ser mais felizes e mais motivadas e isso até poderia ser um fator determinante para a adesão a um Programa de Carona Solidária.

Para VASCONCELOS (1996, p.216), a carona programada é utilizada comumente em muitos países desenvolvidos (principalmente nos EUA), como forma de aliviar o congestionamento das vias expressas. Nos países em desenvolvimento como é o nosso caso, ela tem um alcance limitado por várias razões.

De acordo com esse autor ela tem a desvantagem de propor uma atitude limitante para as pessoas que dispõem de uso exclusivo de um automóvel. Este uso permite o encadeamento eficiente de várias atividades, o que se torna impossível caso a pessoa entre na carona programada. Além disso, a organização de programas de carona programada requer uma certa escala de origens e destinos e capacidade de acompanhamento, que pode ser encontrada apenas em grandes empresas. 
A carona depende ainda de jornadas de trabalho com duração fixa, que são inconsistentes com os deveres e necessidades da alta classe média ( $p$. ex, gerentes e pessoal especializado). Finalmente, ela tem um impacto reduzido, uma vez que a maioria das pessoas nos países em desenvolvimento não tem acesso ao automóvel. Portanto, os recursos alocados no planejamento e operação dessa alternativa devem ser compatíveis com as expectativas reais de seus resultados (VASCONCELOS, 1996, p.217).

Apesar do ponto de vista desse autor que tem razão em algumas das opiniões expostas anteriormente, sabe-se que é principalmente nos países em desenvolvimento e entre pessoas menos favorecidas economicamente é que essa proposta torna-se mais interessante, pela economia que pode gerar. Além disso, em um espaço corporativo, isto é, em empresas, escolas, faculdade, hospitais, essa ideia pode ser facilmente viabilizada tendo em vista a quantidade de pessoas aglomeradas nesses locais. 


\section{Tema 3) Programa de Carona Solidária como política pública}

\section{Entrevistado 1}

“...Ações isoladas de maneira geral, nunca são muito eficientes. Um programa desses tem um aspecto interessante do ponto de vista de despertar a consciência da população, no sentido de que a poluição é importante; que tem muitos veículos nas ruas e que os veículos são os poluidores. Um programa isolado tem seu potencial de impacto muito pequeno, mas é importante que exista. Agora, sem dúvida acho que ele seria muito mais efetivo se estivesse articulado com um plano de ação que fosse mais integrado, que oferecesse inclusive outras opções (como o) próprio transporte público. Essas ações isoladas apesar de tudo têm que existir até para levantar um pouco essa discussão".

\section{Entrevistado 2}

“...Eu não sei como política pública, porque não sei até que ponto o governo pode incentivar. Eu não sei se ele pode obrigar. Incentivar de que forma? Não é só dizer: olha, use a Carona Solidária e tal, mas poderia por exemplo (separar) algumas faixas que fossem pelo menos para carros com 2 ou 3 pessoas. Aí estaria incentivando de forma pragmática. Ou você tem um transporte coletivo que dê condições ou alguma coisa alternativa que seria essa Carona Solidária"...

\section{Entrevistado 3}

“...Na situação que a gente tem (atualmente) em São Paulo eu diria que toda e qualquer iniciativa deve ser valorizada pelo poder público. Ele tem a missão, a obrigação, o dever de apoiar qualquer que seja a iniciativa que tenha a finalidade de reduzir e de melhorar a qualidade do ar. Acho que é obrigação valorizar, criar espaços. Incentivar quer dizer criar instrumentos para que se concretize. Hoje em São Paulo, qualquer e toda iniciativa é válida não só do ponto de vista da redução da poluição do ar, mas ela é válida principalmente 
como um movimento de educação ambiental, de melhoria da sociabilidade, da civilidade como um instrumento também de educação"...

\section{Entrevistado 4}

"...Eu enxergo as duas situações: que é uma opção pessoal, é uma adesão. Eu acho que essa opção pessoal, eu vejo como adesão, adesão a um programa que você acredita que é benéfico para a coletividade e para você também. Eu acho que a Carona Solidária tem que estar inserida em políticas públicas só que aí é uma questão mais complexa ainda. A gente ainda precisa amadurecer na política. Nesse sentido, o que é melhor para a coletividade? O que é melhor para a população, independentemente do partido? Quem foi o pai da ideia? Ou coisas assim"...

\section{Entrevistado 5}

“...Eu acho que pode ser inserida sim, em políticas públicas. Alguns países já adotam isso em carros com mais pessoas, que podem circular numa faixa separada nas grandes avenidas, então acho que isso traz vantagens e o governo deveria incentivar. O que eu não vejo, é muita adesão do governo a essas políticas. De maneira geral, até a política de tirar o ônibus fretado da cidade é uma política que acaba sendo contra, (pois ele) não deixa de ser um transporte compartilhado solidário. As pessoas todos os dias vêm juntas de um bairro distante para a capital e a partir do momento que não foi feito isso, as pesquisas indicaram que essas pessoas passaram a usar o carro. Então, eu acho que seria interessante você ter se não fosse um ônibus, pelo menos vans coletivas, se não fosse o carro pessoal, traria muitas vantagens para as pessoas"...

\section{Entrevistado 6}

"...Ela deveria ser incentivada tanto pelas empresas, quanto pelas pessoas e também como política pública no sentido de oferecer faixas exclusivas para pessoas que estejam em carros que tenham dois ou mais passageiros. No momento em que tiver então, uma clara sinalização nesse sentido, as pessoas vão naturalmente migrar para a Carona Solidária"... 


\section{Entrevistado 7}

"...Eu acho que não deveria ser imposto. Mas o governo deveria gastar energia para incentivar, através de propaganda na televisão. Vamos gastar com uma coisa que é útil, então incentivar mesmo na televisão, propaganda, redução em taxas, por exemplo: você não anda de carro, você divide a carona, então você tem menos taxa, enfim qualquer coisa que é cobrada pelo governo, faixas exclusivas para caronas seria ótimo, poderia gastar energia para beneficiar quem está fazendo a Carona Solidária, para que isso acontecesse mais vezes"...

\section{Entrevistado 8}

“...Uma política pública que envolva carona programada, perde no caminho, não pode ser o motivo fundamental para (uma) política pública. A política pública para levar o transporte individual para o coletivo é muito mais eficaz, quando leva para o transporte coletivo mesmo. A carona programada eu diria que é o $5^{\circ}$ item de uma política de transporte público. Ajuda, é bom, se você tiver a chance, faça"...

\section{Entrevistado 9}

“...Eu acho que não deve ser introduzida como política pública. Qual é o papel do governo? É fornecer a mobilidade adequada para a população (mas) ele não oferece. O papel do Estado é fornecer ônibus, metrô, até ciclovias, de forma que a pessoa possa ir de outra maneira ao seu trabalho. A meu ver, ele vai ser mais um programa dentro de uma empresa, de uma associação dos funcionários, de um grupo ambiental dentro da empresa, de um programa ambiental para redução, complemento. Se o Estado cumprisse bem o seu papel, não seria necessário outras alternativas. Seria como uma fuga, ele estaria admitindo eu não faço bem isso, então eu vou fazer aquilo para remediar. Não, ele tem que fazer bem o seu papel, que atualmente no município, a gente sabe que não está fazendo". 


\section{Entrevistado 10}

"...Eu acho que dentro do contexto de todas as políticas, de todas as ações possíveis e que devam ser incentivas pelo governo municipal principalmente, a carona é uma delas. Enfatizando novamente que ela é uma ação voltada, eu acredito, para um grupo específico de moradores da cidade e que se você tiver no final a adoção de uma série de políticas voltadas para grupos específicos é bem provável que isso tenha um impacto importante nesse conjunto de ações para tentar controlar a qualidade do ar"...

\section{Entrevistado 11}

"...Eu acho que tem que ser incentivado, só que isoladamente é complicado. Tem que ser incentivado o governo passando para as empresas, isso tem que chegar ainda mais perto da pessoa. Então se você faz uma campanha que vá circular pela mídia, já vai despertando as pessoas, criando uma consciência. Daí ela chega no trabalho dela, a empresa também incentiva, organiza, gasta um tempo, investe, pois é muito criativo, tem que se tornar uma coisa bacana mesmo. É fundamental. Se esperar partir do próprio individuo já fica mais difícil porque daí vai depender da consciência de cada um. É difícil mesmo às vezes, as pessoas sentem vontade de contribuir, mas na hora a coisa complica. Mas também essa coisa isolada não resolve, você tem que ter várias medidas juntas"...

\section{Entrevistado 12}

"...Eu fiquei pensando um pouco como essa questão poderia se tornar uma política pública. Talvez algum sistema de incentivos... Eu acho que seria positivo criar essa lógica, provavelmente a constituição daquelas políticas que vem de baixo para cima e não de cima para baixo, empoderamento. Ela vem de uma necessidade da população ou de um processo em que a população por si só já está querendo a política, então ter alguma legislação associada que gere incentivos, ou então, gere incentivos para que as empresas motivem isso nos funcionários, tenham outras compensações"... 


\section{Entrevistado 13}

"...Eu acho que ela deve ser estimulada, isso é comum em outros países. Aqui nós temos um problema de segurança, especialmente aqui em São Paulo. Não só o governo como todas as empresas deveriam estimular isso, como no caso do hospital"...

\section{Entrevistado 14}

“...Eu não vejo isso como uma política pública. Uma política pública depende muito mais de decisões que tenham um espectro maior do que um trabalho desses com Carona Solidária. Eu acho que isso é uma medida paliativa Eu não vejo como uma solução do problema da mobilidade dentro de São Paulo...

\section{Comentários}

A maioria dos entrevistados acreditavam na importância da criação de uma política pública para o incentivo de um programa de Carona Solidária.

Afirmaram também que ações isoladas tinham pouca ou nenhuma chance de trazer resultados efetivos. Disseram que esse tipo de iniciativa devia vir acompanhada e integrada a outras, como por exemplo, melhoria do transporte público.

Nos países em desenvolvimento, o principal objetivo é sempre garantir transporte público adequado para a maioria que dele depende (VASCONCELOS, 1996, p.215). Este tipo de priorização é muito importante, uma vez que muitos técnicos desses países gastam muito tempo imaginando como convencer os usuários de automóvel a usar o transporte público.

Como tal mudança é difícil dentro das condições atuais, qualquer esforço exagerado nesta direção é no mínimo, um mau uso do tempo. Mais ainda, alimenta muito a frustração frente aos parcos resultados alcançados.

Portanto, a preocupação tem sentido apenas quando se adota um enfoque social e político mais amplo (VASCONCELOS, 1996, p.215)

Acredita-se também que as diversas formas de intervenção nas condições de trânsito em São Paulo, devam estar baseadas no entendimento 
adequado do "problema de trânsito", de modo que supere as visões limitadas sobre o "congestionamento" (VASCONCELOS, 1996, p.240).

Para BRUNA (2004, p.891), uma região metropolitana com uma população da ordem de milhões em seu Plano de Transporte Urbano Integrado deveria poder contar com transporte de massa e individual, além do transporte de carga (por rodovia, ferrovia, hidrovia e aerovia). Mas, em termos de gestão metropolitana, cabe ao estado definir os meios e reunir os recursos necessários, inclusive dos municípios membros da metrópole, para a implementação desse plano.

A autora segue dizendo que em termos de extensão territorial metropolitana, levando-se em conta a concentração de atividades e população, talvez seja importante poder contar com um sistema central de operação transporte público de que facilite a gestão da e a integração dos sistemas.

Um sistema desses seria interessante para uma cidade da dimensão de São Paulo, pois integrar os sistemas de trens, ônibus, metrô, taxi com 0 transporte individual, ou seja, se houver um programa de Carona Solidária fazendo parte dessa integração, poderia se ter uma mudança interessante.

Esses sistemas regulados de acordo com a alta demanda das horas de pico e as bruscas quedas dessa demanda entre os picos, onde o número de pessoas que estão transitando para o seu local de trabalho é intenso; permitirão que a cidade tenha eficiência para atingir um equilíbrio de tráfego, com satisfação dos usuários dos sistemas de transporte de massa (Bruna, 2004). 
BRUNA (2004, p.896), conclui que ações como essas, relativas à vazão do fluxo de transporte, são de grande importância para a gestão urbana e ambiental, pois se estendidas pelos operadores dos serviços, pelas concessionárias e pelos administradores públicos, podem se tornar um trunfo para o controle de qualidade.

Em concordância com a autora o controle do fluxo do transporte é muito importante para a eficiência do mesmo no entanto é preciso lembrar que sem a educação da população as medidas de gestão serão insuficientes. 


\section{Tema 4) Fatores determinantes para a falta de adesão ao programa de}

Carona Solidária

\section{Entrevistado 1}

“...Na medida em que você monta um programa como este, eu acho que tem jeito de você trabalhar nisso ... na medida em que você monta um programa de Carona Solidária, imagino que você está definindo áreas, que as pessoas saem todas dali e vem para uma mesma região, então minimamente elas podem até se conhecer, você pode criar algum mecanismo para elas se conhecerem, quebrar um pouco este gelo. Quer dizer... entra aí um pouco o aspecto da socialização: bom, aquele cara ali é meu vizinho, sei que ele vai lá para tal lugar todo dia, então porque não vamos juntos? Quer dizer, eu acho que dá para criar este tipo de coisa sim"...

\section{Entrevistado 2}

“...Para você aderir a um programa de Carona Solidária primeiro você tem que conhecer a pessoa, ter um mínimo de conhecimento sobre aquela pessoa. Não seria tanto o medo mas, talvez seja o fato de que é uma dificuldade, você não ir com seu carro. Com o seu carro você tem uma liberdade maior em termos de horário, você pode até sair do horário que você vai voltar. Você fica preso naquele horário pré-estabelecido, então eu tenho a impressão (que isso pode interferir na decisão de participar) talvez mais por falta de costume do brasileiro, nesta questão de carona. Às vezes, até a questão comportamental, cultural se você vai com outras três pessoas, cada um tem uma conversa, um jeito de ser, eu tenho impressão que esta questão (pode) interferir. Principalmente esta questão de você ser muito ligado à sua liberdade, de sair a hora que você quer, voltar a hora que você quer, entende? Ouvir um programa que você quer no rádio, são coisas a serem trabalhadas"... 


\section{Entrevistado 3}

"...Eu acho que não, porque a Carona Solidária usualmente é entre pessoas que se conhecem. Eu acho que um agravante, é muitas vezes a dificuldade de conciliar realmente os horários, os compromissos. Finalmente, quem tem filhos, fica muito preso aos horários de buscar, levar na escola e às vezes, as pessoas tem horários diferentes no trabalho, enfim. Eu acho que a dificuldade maior é conciliar esses aspectos. Porque usualmente, a carona (se dá) entre pessoas que ou moram no mesmo edifício, ou trabalham no mesmo local, ou próximos do mesmo local. Eu acho que pelo contrário, hoje pelo fato de você andar no carro com mais pessoas, é um fator de proteção e não de insegurança"...

\section{Entrevistado 4}

“...Tendo um pouco por base a pesquisa que eu fiz sobre comportamento humano de jovens no trânsito, eu vejo além da desconfiança, do medo, etc principalmente em cidade grande eu vejo um outro problema, um outro indicador que é o status. O status de eu ter o meu próprio carro, o status de sair da minha casa, ir para o trabalho, de lá eu posso ir para as compras. Quer dizer, eu sou independente, eu sou feliz, eu tenho poder aquisitivo sabe, então é o egoísmo... Tudo isso eu resumiria num egoísmo, numa personificação de que o carro é extensão de mim. Então na carona solidaria será que eu é que vou estar dirigindo? Ou eu vou estar de carona com o outro? E daí, tem a questão da comparação porque eu dirijo melhor, porque o meu carro é mais novo, então eu acho que é tudo uma questão, além desses fatores que você apontou (segurança, entre outros) desses indicadores, principalmente de cidade grande com índice de assaltos, de sequestro relâmpago, mas eu vejo um pouco de egoísmo, quer dizer de não compartilhar o espaço. E o que são as ruas, as avenidas? Um espaço público que tem que ser compartilhado com todos, com aquele que anda a pé, com aquele que anda de ônibus, de van, de moto, de bicicleta, isso não é um espaço próprio meu, (não é) propriedade minha, deve ser compartilhado e às vezes, a dificuldade é de compartilhar com uma única pessoa, que é o caso da carona"... 


\section{Entrevistado 5}

“...A Carona Solidária é feita entre pessoas que já se conhecem, não é uma pessoa que faz sinal na rua e você dá carona. Então, eu acho que o medo não é um determinante, eu acho que talvez (o que) prejudique é essa flexibilidade de trabalho, flexibilidade de horário. As pessoas não tem, às vezes o mesmo horário ou tem flexibilidade para chegar mais tarde ou mais cedo e isso acaba atrapalhando. As pessoas fazem coisas no meio do caminho: para faz uma compra, vai visitar o filho, ou vai visitar a mãe ou mesmo buscar o filho na escola, vai fazer natação, isso já fica prejudicado com a carona, não é? Alguns países como a França estão mudando um pouco o planejamento a partir deste deslocamento das pessoas. Então, eles estão levando atividades que antes ficavam mais na área central, para perto dos bairros. Porque aí a pessoa pode voltar para casa e fazer isso lá: o seu exercício físico, levar o filho na creche, ir ao teatro nos bairros, para não atrapalhar o percurso. Então, poderia ir do local de trabalho direto para o bairro e lá faria suas coisas a pé, de bicicleta ou mesmo de carro, mas (em) percursos curtos. Aqui as pessoas normalmente fazem essas coisas no meio do caminho. Tanto é que eu acho que a Carona Solidária funciona melhor para escola, em universidades ou entre estudantes, acaba funcionando um pouco mais do que entre pessoas que trabalham"...

\section{Entrevistado 6}

"....Acho que não, acho que você não vai ter medo das pessoas que trabalham com você. O que está acontecendo é que as pessoas, às vezes, não querem a Carona Solidária porque é o momento em que as pessoas tem para ficar sozinhos, é o momento que as pessoas tem para o que eu chamo de solidão coletiva; porque põem a música que querem. Talvez, eu acho que se houver uma afinidade entre as pessoas, inclusive dos (mesmos) gostos, tipo quero ouvir o mesmo programa de besteirol de futebol à tarde, eu quero ouvir o mesmo tipo de música, eu acho que daria para dar jogo, para conciliar"... 


\section{Entrevistado 7}

"...Eu acho que é o medo de estar com outra pessoa, você não sabe se (ela) merece confiança ou não e tem outra coisa também: algumas pessoas não são muito pontuais, isso também poderia ser um problema. $E$ ainda tem um terceiro problema que poderia ser contrário, às vezes, as pessoas são ciumentas, elas não querem sua esposa ou seu marido andando no carro de outra pessoa e por algum momento até sozinha se ela for a primeira pessoa a pegar a carona. Isso também pode ser um problema. Talvez, a sugestão de escolher a pessoa do mesmo sexo se bem que hoje em dia, isso também está complicado. Seria assim uma coisa que pode vir contra, se bem que é assim uma maluquice da cabeça das pessoas. Eu mesma não pensaria assim, mas eu acho que muita gente pensaria, isso é uma maluquice porque você não pode isolar o seu marido ou a sua esposa, ele ou ela vai estar em contato com outras pessoas em qualquer lugar onde estiver andando. Não é porque está no carro que passou a ser perigoso, mas, eu sei que as pessoas pensam nisso, eu já ouvi comentários a este respeito"...

\section{Entrevistado 8}

"...Se for carona com desconhecido eu acho que sim. Mas carona dentro de uma empresa você acaba conhecendo seu colega lá e fica sabendo se pode ir com ele ou não.

\section{Entrevistado 9}

"...Em um primeiro momento sim. Se você faz pela internet você fala: bom é (um risco) claro que hoje tudo o que a gente faz, a gente pensa, confia e (desconfia) e (torce) para que que todo mundo faça o melhor. Mas sempre tem aqueles que têm outros interesses. Mas eu acho que é num primeiro momento, mas se você conhecer as pessoas e se familiarizar, eu acho que isso é interessante. Eu por exemplo, vinha para o cursinho de Carona Solidária com dois amigos que tinham carro, rodiziavam e a gente pagava ao invés de vir de ônibus. Isso de Santo André para São Paulo, todo dia. Então era muito mais cômodo, porque todos éramos alunos do terceiro colegial e todo mundo se conhecia. Rachávamos e fazíamos a carona. Quando você conhece, sim. 
Talvez num primeiro momento de entrar pode ser que seja um empecilho então, nesse caso o programa de carona poderia promover o conhecimento, conversa com as pessoas É claro que mesmo aí o cara que estiver interessado em fazer alguma coisa, ele vai também se mostrar num segundo momento. Mas eu acho que é um risco. A sociedade de risco do Ulrick Beck".

\section{Entrevistado 10}

“...Eu não acredito porque essas coisas acabam sendo construídas dentro de um ambiente onde você teoricamente conhece as pessoas que vão dividir este transporte com você. É diferente se você chegar num ponto da zona sul da cidade, reunir algumas pessoas e dizer: vocês querem montar um grupo de Carona Solidária? Eu acho que aí vai ter uma dificuldade muito grande (pois) você realmente não conhece as pessoas. Mas quando se constrói a partir do trabalho ou a partir da escola com aquelas pessoas que se conhecem e por coincidência moram em áreas próximas e tem um trajeto mais ou menos semelhante eu acredito que esse medo da violência possa ser uma justificativa para que isso não funcione"...

\section{Entrevistado 11}

“...Não, eu me lembro do tempo em que eu estudava e morava em Ribeirão Preto e o campus da USP ficava bem fora da cidade e a gente só andava de carona e a minha faculdade era a primeira do campus. A gente pegava carona com quem era da faculdade e com quem não era. $\mathrm{Na}$ ida, às vezes era difícil, mas a volta sempre era de carona. Naquela época você não tinha esse medo, é claro que se tomava alguns cuidados como nunca estar sozinho (a). Nunca se ouvia história como hoje, primeiro porque era no interior e era outra época, mas com certeza isso é um ponto fundamental. Por isso, eu acho que deve começar nos meios, nas empresas, (do) trabalho porque aí você vai pegar carona com alguém que você conhece. Hoje em dia ninguém dá uma carona na estrada. Você tem que começar tendo esse cuidado, aos poucos você vai ampliando esse círculo. Seria interessante que as pessoas fossem mais cidadãs, responsáveis, (se desse para), conhecer outras pessoas fora do emprego, isso seria bacana"... 


\section{Entrevistado 12}

"...O fato de você fazer isso dentro de uma corporação, gera um fator de proteção contra esse tipo de exposição. Se uma pessoa dentro de uma corporação alega esse tipo de situação para não aderir, pode ser que ela tenha outros motivos para não aderir. A carona tem que ser regrada, as pessoas tem que estar condicionadas a um horário de sair ou chegar. Eu não sei se as pessoas aceitam com facilidade mudar isso, estabelecer esse regimento porque por incrível que pareça, talvez (isso) esteja ligado ao fetiche do automóvel. O meio de condução própria significa um certo tipo de liberdade que é paradoxal porque quanto mais pessoas adquirirem essa liberdade entre aspas, mais ficam presas no trânsito"...

\section{Entrevistado 13}

"...Na Alemanha você anuncia num mural e na escola você manda por e-mail. Nas corporações, nos hospitais onde as pessoas se conhecem e sabem que a pessoa trabalha, estuda, ali não teria problema. Eu acho que para o grosso do transporte, funciona"...

\section{Entrevistado 14}

"...Eu acho que pode ser, mas o fato de você viver em uma situação insegura, que você desconfia das pessoas que estão a sua volta, é inviável, você oferecer carona para uma pessoa que você não conhece. Então, eu acho que é possível. Mas eu acho que tem outros fatores como: a questão do horário que você tem que ir com outras pessoas. Quando você opta por um transporte individual você opta por maior liberdade do ponto de vista do horário, você saí a hora que você quer"...

\section{Comentários}

Apesar da insegurança e do medo estarem o tempo todo presentes nas grandes metrópoles, e na cabeça das pessoas, a maioria dos entrevistados não consideraram estes fatores como determinantes para a não adesão a um programa de Carona Solidária. 
Outros fatores como: confiança, flexibilidade de trabalho e de horário, status de ter o seu próprio carro, a facilidade de sair de minha casa e ir para o trabalho e de lá poder ir para as compras significa que são independentes, felizes, tem liberdade. Poder mostrar que tem poder aquisitivo, ou até mesmo expressar uma forma de ciúmes, entre outros, pesaram muito mais para os entrevistados.

Para GUIDDENS (1991, p.102) a confiança pessoal torna-se um projeto, a ser "trabalhado" pelas partes envolvidas, e requer a abertura do indivíduo para o outro. Onde ela não pode ser controlada por códigos normativos fixos, a confiança tem que ser ganha, e o meio de fazê-la consiste em abertura e cordialidade demonstráveis. Nossa preocupação peculiar com "relacionamentos", no sentido em que a palavra agora tomada, é expressiva deste fenômeno. Relacionamentos são laços baseados em confiança, onde a confiança não é predada, mas trabalhada, e onde o trabalho envolvido significa um processo mútuo de auto revelação.

Dessa forma, a confiança é um grande determinante das relações pessoais que levam à reciprocidade fazendo com que as pessoas tenham liberdade e assumam compromissos seja no trabalho, no lazer, na escola ou até mesmo ao compartilhar o seu automóvel com o outro.

Segundo VASCONCELOS, (1996, p.104) o significado do automóvel nas sociedades contemporâneas é multifacetado. Nenhuma característica pode explicar sozinha porque esta tecnologia influenciou muito nossas vidas. Roland Barthes, um filósofo francês, descreveu o automóvel como a "catedral gótica dos nossos tempos" (citado em Sachs, 1992). Assim como a catedral não é apenas um abrigo, o automóvel não é apenas um meio de transporte.

Para BARTHES, citado por VASCONCELOS (1991), quatro visões convencionais cobrem a maioria das concepções sobre o automóvel.

A primeira delas é a que identifica o carro com os símbolos de poder, status e riqueza, ou seja, às ligações que ele pode estabelecer entre posse, demonstração pública e riqueza do seu proprietário. Nesse sentido, o carro é um símbolo para a demonstração da superioridade e do prestígio social e 
técnico. Esta visão pode ser denominada antropológica, na medida em que representa uma forma de exteriorização de símbolos dentro de um grupo de convivência para o reconhecimento e o reforço individual (Schimidt-Ralemberg, 1985, 124 apud VASCONCELOS, 1996).

A segunda visão corresponde aos símbolos de liberdade e privacidade. No primeiro caso, envolve a expectativa de circulação livre e desimpedida no espaço e noções de velocidade e agilidade. No caso da privacidade, "o automóvel nos permite viajar quase sem limites por todos os locais do domínio público, enquanto permanecemos em um mundo completamente privado" (Stone, 1971, 95 apud VASCONCELOS, 1996).

A terceira visão corresponde às ideias de juventude, confiança própria e prazer pessoal. Está mais comumente associada à fase de adolescência. Entretanto, pode ser facilmente identificada na idade adulta, quando o automóvel aparece como um meio para desenvolver experiências emocionais relacionadas ao ato de dirigir e ao prazer estético. Esta visão pode ser denominada psicológica.

E a quarta visão relaciona-se à utilidade do automóvel como uma tecnologia que permite uma mobilidade sem precedentes na história dos transportes e a maior capacidade de conexão possível de viagens sequenciais. A decisão de comprar um automóvel e de rejeitar o transporte público - é vista como uma consequência natural de uma comparação racional entre custos e benefícios de várias oportunidades de consumo, visão que é apoiada por uma ampla bibliografia especializada (Button, 1992; Small, 1992). Ela representa uma mudança importante, à medida que supera as limitações das visões superficiais descritas anteriormente, ao propor a utilidade real do automóvel como o principal fator explicativo da sua valorização. Esta visão pode ser denominada econômica (Schimidt-Ralemberg, 1985, 124 apud VASCONCELOS, 1996). 


\section{Tema 5) Futuro da cidade de São Paulo x mobilidade}

\section{Entrevistado 1}

“....sem futuro e não é só São Paulo, claro que é o expoente do Brasil neste aspecto e em vários outros também. A questão da mobilidade é importante. Tenho vários amigos que a queixa cotidiana é essa, de perder não sei quantas horas no trânsito todos os dias, para ir de um lugar para outro porque tem que ir, porque faz parte do seu trabalho. Então, as pessoas tem que se movimentar pela cidade e isso realmente é um fator limitante e assim a média da população está perdendo horas e horas no trânsito. Todos os dias vai perdendo um tempo precioso que poderia estar fazendo coisas muito mais importantes do que estar no trânsito. Se isso se mantiver, e não for feito nada com esta situação, só vai se agravar. E está acontecendo já em outras cidades, você viaja pelo Brasil e começa a ver, Salvador por exemplo, que é uma cidade que eu visito muito e há muitos anos, você começa a perceber que cada vez mais está ficando impossível se locomover pela cidade. Lá além de tudo, não tem outras opções, não tem metrô e o número de veículos só aumenta e nas ruas, qualquer pequena avenidinha já (fica) tudo congestionado, então está ficando um caos"...

\section{Entrevistado 2}

“......Eu acho problemática esta cidade. Eu estou programando um evento para 2015 aqui, onde a questão da mobilidade da cidade é um fator limitante. Duas coisas: a mobilidade e a segurança; você vai trazer estrangeiros para cá (um número grande) e o evento tem horários fixos, as pessoas tem que chegar lá naquele horário e a cidade não oferece isso. Pelo menos com o metrô, você tem uma condição de (deslocamento).(É preciso) também uma infraestrutura de hotéis próximos para que você possa ir a pé, rapidamente. Então, eu acho que essa questão de mobilidade, afeta a cidade do ponto de vista da saúde das pessoas, do ponto de vista emocional, ela afeta economicamente, porque há grande perda de tempo no trânsito, afeta também as pessoas em termos vamos dizer do tempo em que elas perdem no trânsito. Isso é um fator por 
exemplo, de perda de horas de sono, porque elas tem que levantar mais cedo para ver se pegam menos trânsito, então eu acho que se a cidade não resolver isso, aí a tendência é parar...

\section{Entrevistado 3}

“...Eu vejo um futuro péssimo eu acho que ela não vai ter mobilidade, vai ficar engessada, não vamos conseguir ir para lado nenhum, daqui uns dias nem a pé, mais a gente anda em algumas ruas da cidade. Eu acho péssimo e acho que a situação demanda medidas drásticas de enfrentamento”...

\section{Entrevistado 4}

“...Eu acho que é de caos para pós caos. Eu creio que chegou no limite, não dá para piorar mais, tem é que achar alternativas para melhorar. Eu creio numa somatória de forças, uma somatória de alternativas e melhorar o transporte público, este transporte público de hoje, pensando em metrô e pensando em ônibus. Eu sonho com uma São Paulo com VLT- Veículos Leves sobre Trilhos que levam um grande número de pessoas, que é confortável, que não tem o custo do metrô porque ele não é subterrâneo e eu não sei o que que emperra. Emperra um pouco, o processo histórico. O que que é o processo histórico? Enquanto capitais européias e outros países mantiveram o trem para ligar uma cidade a outra e o bonde para fazer o transporte dentro da própria cidade, o Brasil teve que eliminar ferrovias e multiplicar as rodovias, (usando) combustível importado, na época caríssimo e poluente. (É preciso que) o metrô continue existindo, mas que não deteriore (nem) os ônibus, e quem sabe o VLT e a Carona Solidária (tornem-se realidade), porque olhe se 100 pessoas aderirem são 50 carros a menos, o impacto é grande”...

\section{Entrevistado 5}

“...O que a gente vê é o agravamento da mobilidade e as reações que são feitas de forma individual. Muitas pessoas tem mudado sua moradia para perto do trabalho. Eu vi a reportagem de um urbanista que falava assim que o tempo

em que as pessoas ficam no emprego não é o mesmo da casa própria. É uma coisa diferente, por exemplo, dos Estados Unidos em que as pessoas geralmente alugam casa. Então, não é todo mundo que tem casa própria; no 
Brasil existe essa ideologia em busca da casa própria e às vezes, a pessoa compra uma casa própria num lugar e tem até uma dificuldade em se desfazer desse imóvel para comprar um imóvel próximo do seu local de trabalho. Então, isso também é um complicador. Acho que essa Carona Solidária talvez nos Estados Unidos, pegue um pouco melhor porque você tem os bairros dormitórios, depois você tem os grandes centros geradores de empregos e aí pega aquela estrada e a rota é sempre a mesma. Aqui não é uma cidade muito trincada. Você tem trabalho em tudo quanto é canto, você tem moradia em tudo quanto é canto e aí, acaba dificultando. Eu acho que as questões culturais acabam influenciando como também um certo individualismo entre as pessoas. Você pode ter a carona muito mais presente no âmbito familiar, vamos para algum lugar aí leva uma filha, leva o marido, a família em bloco, um dá carona para o outro. Mas, no âmbito de trabalho, eu não percebo muito isso. Aqui mesmo na faculdade que as pessoas tem uma preocupação com o meio ambiente e com a saúde, têm dificuldade de locomoção e tal. Eu acho que a solução (de comprar) primeiro uma moto, que é uma solução individual, acaba ganhando. A pessoa então, compra uma moto porque (acha que vai) a hora que quiser, para onde quiser e economiza tempo"...

\section{Entrevistado 6}

“...A pergunta é qual mobilidade? Já não existe não é? Até hoje a nossa previsão de chegar aos locais é altamente incerta ou a gente chega muito cedo ou chega muito tarde. A gente vai pegar um avião em Cumbica, você não sabe a que hora você saí. Quer dizer, o tempo perdido nisso, é muito ruim e está piorando. Piorando porque a frota aumenta, existem estímulos para que a frota aumente e não comporta mais esse tipo de mobilidade. Tanto, que aparece hoje muito forte na campanha para prefeito, o tema mobilidade. Então, isso é um sinal de que há uma previsão de melhoria de transporte coletivo como tema central da campanha. Acho que mobilidade, saúde e educação são os três temas que mais tem ocupado (espaço nas campanhas). Dentro da saúde então, eu acho que está tão ruim que está criando condições para que a gente modifique"... 


\section{Entrevistado 7}

"...(Vejo) um futuro negro, eu não consigo nem imaginar. Vai travar a cidade inteira porque cada vez mais carros são produzidos, são vendidos. Isso não pode parar porque a indústria tem que funcionar, tem muita coisa envolvida, é emprego das pessoas, é a economia, tudo esta girando, não pode parar e a malha viária, é limitada. Tudo bem, ela pode melhorar um pouquinho, você abre uma estrada onde não tinha, melhora uma ponte, faz uma engenharia de tráfego melhor, mas no vertical não vai parar de crescer e por mais que você faça reformas na malha viária, isso é limitado. Vai chegar uma hora que realmente vai travar, uma hora vai travar, não dá para continuar como está"...

\section{Entrevistado 8}

“..(Futuro) Negro. Não dá para manter a imobilidade como está...

\section{Entrevistado 9}

“...Terrível, não é? Eu fiquei 6 meses na Espanha fazendo pós-doutorado em Madri. O que tem de melhor em Madri é o transporte público, e aí eu pensei em alugar um carro por 6 meses ou até comprar um carro velho e tal. Eu fui ver o preço da garagem e que as ruas não tinham onde parar e cada vez que eu fosse parar, eu teria que pagar o estacionamento. Só que aí eu vi a qualidade do transporte. Pensei, eu não preciso de carro. Realmente eu fiquei 6 meses andando a pé, sem precisar em nenhum momento falar, porque que eu não tenho carro, porque o transporte (público) é muito bom. Ele serve, não é um ônibus que anda duas horas. O ônibus anda no máximo 30 minutos, você pega às vezes, três ônibus para ir ao mesmo local. Mas eles passam de 10 em 10 minutos você sabe que vai chegar ali, vai pegar outro e em 30 minutos você está no seu trajeto, no máximo. Você planeja, confia, porque é cronometrado por computador ele tem que passar naquele horário, é tudo eletrônico. Quer dizer, é outro sistema. São Paulo está um caos, a quantidade de carros cada vez aumenta mais, a gente já não tem mais espaço, os ônibus estão péssimos, o metrô que vai indo muito lentamente, muito aquém do que poderia ir. Outra coisa, o Brasil só prioriza o transporte rodoviário e os trens? Nós tínhamos antes trens muito bons, agora a gente tem algum aí para inglês ver para não 
dizer que não tem. Mas eu acho que o Brasil deveria investir maciçamente em transporte ferroviário, não só metrô, mas trem de superfície também tipo VLT, não precisa ser rápido. Poderiam ser os comuns mesmo, mas que tivessem um atendimento, não como agora em que as pessoas vão penduradas, que têm risco. Lá dentro, (deve haver) um sistema adequado que tenha um controle, que tenha confiabilidade, que eu possa chegar lá e saber que o trem vai passar naquele horário. A Europa inteira trabalha com trem e funciona muito bem. Porque que nós aqui somos diferentes? A cidade toda deveria ter um projeto, o investimento inicial é alto, mas ao longo do tempo ele se mantém. A manutenção é muito pouca, você fez o trilho, nunca mais você terá que recapear o trilho. A rua não, todo ano você tem que recapear por causa da qualidade do asfalto que nós temos. Quer dizer, é muito (mais) caro manter uma rodovia, do que manter uma linha de trem. De trem podem ir 20 vagões puxados por uma mesma máquina, então eu tenho trem de transporte, tenho trem de carga, de pessoas, e de alimentos ponto-a-ponto. Se a gente fizer uma linha adequada, ele pode chegar como centro de transporte de local-a-local, (isto é) muito interessante. Eu acho que hoje se não tiver mudança, se não tiver investimento, vai ser um caos. Hoje já está um caos“...

\section{Entrevistado 10}

“...São Paulo vai acabar parando! Quer dizer, você tem uma cidade de dimensões muito grandes, você tem infelizmente um deslocamento obrigatório de um extremo ao outro porque como todo mundo sabe, o local onde você mora não é necessariamente o local onde você pode trabalhar, não é? Feliz daquele que consegue trabalhar não no mesmo bairro, mas na mesma região da cidade, mas isso não é o que acontece. Existem inúmeros exemplos de pessoas que acordam às 4 horas da manhã, 3h30 da manhã e que moram na zona sul e têm que chegar ao extremo norte da cidade para trabalhar. Então, faz uma jornada de horas para chegar no trabalho, outra jornada de horas para voltar para casa, sendo que o que é mais penalizado nesse processo, é o tempo em que ele fica em casa. Então, esse deslocamento está ficando cada vez mais difícil, porque a oferta do transporte público, não é suficiente não só em quantidade, mas também em qualidade, para convencer de maneira radical, de maneira contundente, a pessoa a dizer o seguinte: eu não vou sair 
de casa de carro. Mesmo que a pessoa agora tenha facilidade, por exemplo, de utilizar metrô e ônibus talvez ela não consiga fazer isso num trajeto curto. Talvez ela tenha que se deslocar em um pedaço desse trajeto, de carro. É fundamental que se tenha por objetivo nos próximos anos, efetivamente construir uma rede de transporte público envolvendo todas as opções que consigam oferecer esse transporte como uma alternativa real e viável. Há cinco anos eu não venho mais de carro para cá. Moro em São Caetano, com o tempo foi ficando mais fácil fazer esse trajeto. Hoje eu não preciso efetivamente me deslocar para cá de carro, mas se eu ficar aqui o dia todo, se por acaso eu tiver que sair daqui para ir a uma reunião na cidade universitária, eu vou ter problemas para fazer esse trajeto. Existe uma mudança, uma melhoria nesse processo, ela é muito lenta, mas isso precisa ser incentivado. Além da redefinição do funcionamento da estrutura da cidade (é preciso) levar o emprego para próximo das regiões mais afastadas do centro, criar núcleos auto sustentáveis onde as pessoas (possam) morar, trabalhar e se divertir, sem ter que deslocar ao longo da cidade. Acho que isso seria importante para tentar melhorar a mobilidade. O que a gente vê hoje é uma situação preocupante que se não for adequadamente abordada e com certa velocidade, vai fazer com que a cidade fique meio engessada"...

\section{Entrevistado 11}

"...Terrível, que mobilidade? Imobilidade (sim), a cidade vai se transformar em um grande estacionamento, o futuro não é promissor dessa forma"...

\section{Entrevistado 12}

“...Caótico, eu não tenho a menor dúvida. Alternativas vão aparecendo, eu não sei como. Tem algum processo de auto organização que vai ocorrendo, uma certa autonomia das pessoas. As organizações vão tentando encontrar alternativas, porque é evidente que todo mundo está sofrendo muito com o crescente problema de deslocamento. A mobilidade urbana é um dos maiores problemas que afetam a qualidade de vida contemporânea. Hoje você vê no Brasil empresas que estão dando como alternativas para o funcionário trabalhar um dia da semana em casa. As pessoas podem por si só encontrar essa alternativa no caso de profissionais liberais. É um exemplo de resposta de 
adaptação à crise. O rodízio foi uma resposta, já está implantado não dá conta, logo poderá ser implantado um sistema de pedágio nas áreas mais centrais de São Paulo. Eu tenho certeza que isso vai entrar em vigor. Tem uma outra medida para atenuar isso. Aquelas pessoas que queiram continuar andando com seu carro sozinho vão ter que incorporar este custo a mais, que é esse pedágio ou então utilizar o transporte público. Os altos preços do estacionamento pode ser que façam as pessoas pensarem ao sair de carro. Uma diária no Aeroporto de Congonhas custa $R \$ 100,00$ e tem quem pague. Isso porque tem ônibus que chega até o aeroporto.

\section{Entrevistado 13}

"...Preocupante. Nós temos aumentado a morbimortalidade no Brasil, em São Paulo, pelos efeitos da poluição. Dados da OMS comparando 2004 e 2008 mostrou que na China, Rússia, Brasil e Índia, a mortalidade estimada aumentou. Comparativamente no Japão, Alemanha, mesmo Indonésia e Estado Unidos, a mortalidade reduziu, o número de mortos reduziram. Porque há um esforço mais antigo daqueles países em reduzir a poluição, especialmente com atuação mais forte na área da redução da poluição veicular. Aqui nós vamos ter um problema de travamento grande no trânsito, que já está acontecendo e com a quantidade de carros circulando, fica impossível você ter uma política adequada de redução da poluição mesmo que você melhores os combustíveis. São mil carros licenciados por dia, no caso da cidade de São Paulo. Então você vê um futuro sombrio, se nós não investirmos em transporte público, ônibus, metrô e incentivarmos as medidas que vão complementando o transporte de massa...

\section{Entrevistado 14}

"...São Paulo vai se tornar inviável. Eu acredito que ao longo do tempo com a inviabilidade da situação, essas soluções comecem a ser discutidas porque na medida em que existe um prejuízo talvez econômico, do ponto de vista de mobilidade entre as pessoas em relação ao horário de trabalho e em relação ao deslocamento, que eu acho que é o principal ponto. Ao demorar 2 horas para chegar ao seu trabalho, eu acho começam a ser discutidas soluções do 
ponto de vista trabalho e moradia. Com isso, se comece talvez a discutir um planejamento para a cidade"...

\section{Comentários}

Todos os entrevistados demonstraram uma grande preocupação em relação à mobilidade urbana e argumentaram que se nenhuma ação efetiva for tomada urgentemente para melhoria do trânsito na cidade de São Paulo, as pessoas se tornarão reféns do congestionamento por elas criado.

Essa problemática se dá pelo fato de não haver uma oferta de transporte público eficiente que atenda à demanda. Sendo assim, a circulação humana se torna difícil uma vez que para determinados deslocamentos, é obrigado utilizar o carro.

Para que haja uma melhora no trânsito, algumas medidas de restrição ao tráfego deveriam ser tomadas, de acordo com VASCONCELOS (1996, p.217), pois elas afetam diretamente as necessidades de reprodução social das pessoas, uma vez que impõem restrições aos seus deslocamentos. Assim essas medidas sempre enfrentam oposição imediata, cuja intensidade depende do nível das restrições impostas. 


\section{Tema 6 - Opiniões sobre a decisão de restringir o vale-transporte para quem aderir ao projeto Carona Solidária.}

\section{Entrevistado 1}

"...A ideia de você instalar um programa deste tipo em Instituições grandes como hospitais públicos escolas, faculdades, eu acho que em vários lugares onde isso pode servir porque é um lugar que concentra um muita gente que vem todos os dias para trabalhar, é boa. Agora você não pode limitar quem participar e (dizer que) não vai ter vale-transporte. Eu acho que não é bem por aí, eu acho que deveria ser conversado, não sei como lidar bem com essa situação, mas deveria ser pensado melhor porque eu acho que esse tipo de programa, como eu falei, ele sozinho, desarticulado não vai resolver o problema. Mas, eu acho que é uma iniciativa que se tomar corpo pode ter algum impacto no sentido de tirar veículos das ruas, que é o que a gente está precisando, não é? Tirar veículos das ruas. A questão da mobilidade urbana está colocada. A poluição do ar afeta muito a saúde e a população já percebe isso"...

\section{Entrevistado 2}

“...Eu acho que é interessante. Uma coisa não tem ligação com a outra, porque eu não sei como é dado esse vale-transporte, o que que você tem que fazer para obter o vale-transporte? Se você vem de carro você acaba não utilizando o vale-transporte, (o mesmo) se você vem de Carona Solidária. Eu não sei a que isso pode ser atribuído"...

\section{Entrevistado 3}

"...Falta uma política institucional, embora o hospital tenha dito que ele tinha interesse, isso não tinha importância realmente. O fato de ser uma iniciativa da instituição, muitas vezes isso tem caráter muito mais de propaganda, não é? Fazer marketing não é? do que ser propriamente uma política institucional, uma preocupação"... 


\section{Entrevistado 4}

"...É complicado, muito complicado, porque aí pode ser uma coisa não intencional. Alguém que pensou numa possibilidade e virou um boato e um boato caminha, ele tem força de verdade. Aquilo que poderia ser uma possibilidade de não ter mais o vale transporte, de repente já não tem mais 0 que dizer, já se concretizou. Ou então, para solapar a ideia, alguém quis boicotar, solapar ou achou que isso poderia resultar em atraso, porque um vai passar na casa do outro, porque moram perto. Mas é de estranhar porque foi solicitação da Instituição e daí vira alguma implicação. Nossa, é difícil opinar porque o que a gente pode é levantar hipóteses. Será que com isso pensaram em ter menos gastos? Quer dizer, agora eu não preciso gastar.... Mas vamos pensar que se a ideia se alastrasse para a totalidade, se metade aderisse (1.500) e se joga com essa possibilidade de não atribuir vale-transporte e muito menos garantir os seguros de saúde, então poderia haver uma diminuição mensal de 1.500 funcionários, então poderia até ser uma medida de economia para a empresa. Mas não é uma economia grande, porque você está falando de vale-transporte e não do salário deles e o vale-transporte é um percentual pequeno em relação à transporte e à salários e encargos sociais. Então, é de se estranhar, é de se estranhar mesmo porque o vale-transporte deveria ser mantido, os direitos assegurados e os benefícios para os funcionários e haveria então, enorme adesão"...

\section{Entrevistado 5}

“...Bom, a primeira coisa é preponderante. A do econômico não é? a racionalidade das pessoas mesmo dos administradores. Eu entendo que pessoas elas viajavam por transporte coletivo, por isso elas ganhavam valetransporte porque a pessoa que vai com o carro ela não tem direito a valetransporte. Eu acho que para o hospital funcionaria bem. Porque você tem um horário de turnos começam sempre sete horas da manhã, termina..., então as pessoas saem do trabalho no mesmo horário e frequentemente moram em locais afastados do centro urbano e isso poderia ter um impacto maior"... 


\section{Entrevistado 6}

“...É uma burrice! Resumidamente burrice, se você quer fazer um programa de sustentabilidade e ao mesmo tempo você pune. As pessoas usam o valetransporte para outras coisas além de trabalhar, então esse é o tipo da miopia administrativa. Isso é falta de uma visão geral, de uma visão mais sofisticada do que seja sustentabilidade"...

\section{Entrevistado 7}

“...(O motivo) é o baixo salário basicamente, se eles fossem melhor remunerados nem pensariam nisso, pensariam primeiro no meio ambiente, pensariam primeiro até no conforto de não ter que dirigir todo dia, mas, não pensariam no dinheiro que é muito pouco do vale-transporte. Muitas vezes as pessoas procuram até não gastar o dinheiro do vale-transporte para poder sobrar, enfim tem muita gente que usa o vale-transporte para outras coisas: troca com alimentação, para mim a maior informação disso é que estão sendo mau remunerados"...

\section{Entrevistado 8}

"...Você vê aí a falta de engajamento de algumas pessoas, poucas, que estragam tudo. Uma pessoa dessa fica querendo tirar proveito de uma iniciativa pró-ambiental para economizar uns trocados do vale-transporte que ele não fez nada para merecer. Ele com isso derruba uma ação dessas. Se ele não fizesse nada seria ótimo. O cara que inventou este boato, provavelmente não era bem um boato e sim, a intenção de se aproveitar do programa para fazer uma pequena economia, é dessas pessoas que se não existissem fariam um bem para o mundo. Não constroem nada e não deixam construir. Infelizmente é esse tipo de pessoas que existe"...

\section{Entrevistado 9}

“...Isso seria ótimo, a empresa te dá um programa no qual você vai ter mais conforto, vai chegar de ponto-a-ponto, você vai sair num horário e não vai precisar esperar o ônibus. Você quer isso? O vale-transporte é a questão do monetário, porque eu acho que o funcionário entende assim: a empresa tem 
obrigação de me pagar e no transporte solidário quem paga são as próprias pessoas que pagam então o combustível. Porque eles não querem perder direitos, trabalhador nenhum quer perder seus direitos. Direitos são difíceis de ser conquistados e o vale-transporte, vale alimentação é um direito do trabalhador. No momento que ele fala olha eu vou tirar, mas você não usa. Pode ser que se eu for de carona todos os dias vai sobrar a minha cartela, mas se eu precisar eu tenho. Então é aquela coisa, primeiro o direito, segundo, é assim eu vou ganhar. Se eu não usar aqui, eu vou usar no final de semana, vou dar para o meu filho ir para a escola, vou dar para o meu pai passear, qualquer outra coisa. O primeiro é não perder o bilhete, e de certa maneira é um direito conquistado. Se esse direito for mudado de outra maneira que eu acredito que ela não vai poder fazer, a não ser que ela mude. Ou então, aderir e ver o quanto gasta, eu vou dar o valor do vale-transporte dos três ou dos quatros que estão indo para você pôr a gasolina. É a questão econômica, ninguém quer perder recursos"...

\section{Entrevistado 10}

“...A percepção é que eu estou te oferecendo uma coisa bacana, que é a Carona Solidária, mas mesmo que não seja uma informação oficial e sim um boato. Mas se você adere, eu vou te tirar uma parte do salário. É difícil porque no final das contas, a gente sabe que o vale transporte é vale transporte, mas em determinados momentos do mês, ele é moeda de troca, então, seria um motivo bastante forte é claro, não para ter esse efeito de impedir a adesão. Lembrando que na estrutura de um hospital você tem muitos funcionários que efetivamente dependem do vale transporte, eu acho que é uma situação bastante difícil"...

\section{Entrevistado 11}

“...Sempre que você mexe no bolso das pessoas é isso que acontece. Se o hospital quer implantar uma política nova tem que ter incentivo e não desincentivo. Não adianta você tirar o vale transporte, porque esse custo que você teria dando o vale transporte, as pessoas não teriam que ir de carona. Você está economizando tanto do outro lado, você diminui a poluição, você diminui acidente de trânsito desde o carro e do atropelamento, você começa ter 
um trânsito mais amigável e diminui tudo. Você economiza muito com isso, enfim todas as ações que tem que ser feitas para dar conta do prejuízo que esse trânsito trás, é uma economia"...

\section{Entrevistado 12}

“...Eu acho que a Incorporação foi oportunista, talvez ela estava vendo nisso desde o início uma oportunidade para reduzir o vale-transporte. E uma política de sustentabilidade que é uma opção das empresas e elas não fazem isso a toa. Elas fazem isso tanto com interesse direto em minimizar recursos porque muitas vezes poluição significa perda de recursos então otimizar a produção, tornar menos sustentável com menos resíduos, com menos perda de energia é também uma questão de economia direta da indústria. O deslocamento dos funcionários é um custo socioambiental tem que incorporar. É uma das medidas que tem que ser incentivadas"...

\section{Entrevistado 13}

“...Primeiro que se eu fizesse parte da direção do hospital eu faria ao contrário. Quem aderisse a isso eu aumentaria o valor do vale-transporte para incentivar mais ainda. Não sei se isso foi determinante. Eu acho que é um problema cultural de individualização do carro especialmente (os) médicos e profissionais de nível superior. Isso é pior, dependendo do hospital, você tem um pessoal de renda média mais alta, esse pessoal vai aderir mau. Talvez a adesão possa ser maior na população de baixa renda onde o que pesa é mais o custo do que a população. Eu não sei dizer qual seria a razão principal, mas seria uma combinação talvez a boataria, falta de tradição pode ser que na instituição hospitalar tenha a maioria das pessoas com baixa renda. As pessoas de renda media mais alta são mais elitistas apegadas ao carro e também fazem mais locomoções durante o dia para mais de um emprego principalmente no caso do médico são vários fatores aí”... 


\section{Entrevistado 14}

"...Eu acho que você tem que ter uma vantagem dar um estímulo para esse trabalhador em troca daquele benefício que ele conquistou. Mas eu acho que a dificuldade de você equacionar horários, acertar/casar quem mora perto de quem essas pessoas terem o mesmo horário de chegada e de saída do trabalho. Eu acho que essa talvez seja a principal dificuldade em relação a isso. Tem também a questão da afinidade porque tem pessoas que moram próximas e não tem afinidade isso as vezes você tem até incompatibilidade"...

\section{Comentários}

A maioria dos entrevistados acha que o vale-transporte é muito importante e dificilmente os funcionários de uma empresa abririam mão de qualquer coisa que the seja oferecido. Sabe-se que é um benefício necessário para esses trabalhadores.

Sabendo que a Lei $\mathrm{N}^{0} 7.418 / 1985$ que institui o vale-transporte em seu artigo $2^{\circ}$, letra a) diz que "o referido benefício não tem natureza salarial, nem se incorpora à remuneração para quaisquer efeitos", isso mostra claramente a fala dos entrevistados quando eles argumentam que o vale-transporte não serve apenas para o uso no transporte coletivo e sim como moeda de troca em momentos difíceis durante o mês e como complemento quando o trabalhador não dispõe mais de seu salário.

Para os entrevistados sempre que uma empresa quiser implantar algo novo mesmo que seja para o bem de todos os trabalhadores, ela sempre deverá oferecer alguma coisa em troca para que aquela adesão seja mais bem aceita, ou seja, o vale-transporte é um direito adquirido assim como os outros tipos de vales: alimentação, gás entre outros, no entanto, esse dinheiro poderia ser incorporado ao ordenado dos profissionais de saúde de uma outra maneira com apoio legal. Eles não perderiam seu direito e poderiam aderir ao Programa de Carona Solidária. 
Cabe então trabalhar mais no sentido de contribuir para o aprimoramento da consciência das pessoas em geral.

Há quem diga ainda que a Instituição Hospitalar quis aderir a mais um projeto ambiental que é o da Carona Solidária, por questões de marketing, pois atualmente as empresas que trabalham a sustentabilidade são mais bem vistas no mercado. 


\section{6 - CONCLUSÃO}

Tendo identificado os conhecimentos e percepções que os funcionários de uma Instituição Pública Hospitalar (ICESP) tinham sobre as questões ambientais relacionadas à saúde em particular os problemas relacionados à poluição do ar na cidade de São Paulo e verificado como um programa de Carona Solidária poderia contribuir para que houvesse melhoria no ambiente de São Paulo, obteve-se como resultado a confirmação de que todos os respondentes da pesquisa que disseram sim demonstraram ter preocupação com a qualidade do meio ambiente, principalmente pensando nas futuras gerações constituídas por seus filhos, netos, entre outros.

No entanto, tratando-se de questões práticas como compartilhar o automóvel para participar da Carona Solidária, notou-se um certo desinteresse por parte dos respondentes.

Alguns disseram nos questionários que aceitariam a carona se fosse com pessoas conhecidas, colegas de trabalho, colegas de escola. Isso já mostra que algumas pessoas procuram mudar suas atitudes em favor do meio ambiente e de sua saúde, mas, querem fazer isso com segurança.

Essa questão, ainda é um mito para eles. Não é fácil mudar atitudes mesmo quando se tem certeza de que aquilo irá trazer melhoras para sua vida. A convivência com o outro, dividir com os outros seu espaço, sua solidão, seus problemas, ainda é muito difícil para a maioria das pessoas. Às vezes, elas até querem, tem vontade, porém, o seu EU fala mais forte.

Percebe-se claramente que como todas ideias novas, são usualmente contestadas, a Carona Solidária dificilmente será aceita de imediato.

A questão cultural de ter e sair com um carro novo, do ano, ainda é um valor para uma parcela da população. Não querer o outro no carro porque não sabe como será o seu comportamento como também decidir ir às compras ao sair do trabalho ou ir ao cabelereiro, isto é, mudar o trajeto anteriormente estipulado para encontrar outros amigos, também são motivos para não querer assumir o compromisso com a carona. 
Para algumas doenças a população entrevistada ainda não conseguia estabelecer a relação entre saúde e ambiente. No momento em que essas pessoas começarem a perceber com profundidade os problemas de saúde e ambientais causados pela poluição do ar, talvez elas mudem suas atitudes.

A maioria dos entrevistados nos questionários aplicados considerou que a população tinha a percepção da existência de problemas de saúde decorrentes da poluição do ar.

Todos os respondentes sabiam que a poluição do ar faz mal à saúde, porém, influenciados pela cultura, onde apenas se faz o que a sociedade impõe para que se sintam parte dela, torna-se difícil mudar atitudes e comportamentos, como dar e receber carona.

Esses profissionais afirmaram que a Carona Solidária é uma iniciativa muito interessante para ser usada localmente (empresas, faculdades, escolas, hospitais entre outros) desde que tenham um número expressivo de funcionários circulando. Possibilita que haja interação entre as pessoas que fazem o mesmo trajeto, todos os dias, podendo assim selar laços afetivos e de amizades.

Alguns consideraram que se essa idéia fosse incorporada como política pública poderia até facilitar a utilização desde que viesse acompanhada de outras medidas de circulação já existentes.

Para eles, São Paulo encontra-se em estado de alerta por conta da quantidade de carros existentes em suas ruas e avenidas e toda e qualquer iniciativa voltada para resolver ou minimizar essa problemática, deveria ser discutida e implementada na tentativa de diminuir o número de veículos automotores.

Neste estudo ficou evidente que não será de um dia para o outro que as questões relacionadas com o meio ambiente serão vistas como prioridade pelos governantes.

A questão da Carona Solidária para ser aceita vai precisar de participação popular, se houver interesse em tê-la como mais uma opção de 
transporte. É preciso lembrar que as políticas públicas são formadas a partir das necessidades de determinados grupos populacionais.

Acredita-se que a educação ainda seja o melhor caminho para que essas mudanças ocorram, e que a partir daí haja uma alteração no comportamento de cada um.

Esse trabalho foi importante por mostrar que sempre é possível contribuir com idéias e ações para melhorar a poluição do ar na cidade de São Paulo. 


\section{7 - RECOMENDAÇÕES}

1 - Para a Instituição Hospitalar onde foi realizada a pesquisa:

Possibilitar que os funcionários interessados possam participar de um Programa de Carona Solidária:

- realizar palestras para tirar dúvidas existentes;

- proporcionar algum incentivo que leve esses funcionários a querer participar do projeto;

- garantir que mesmo participando recebam todos os seus benefícios principalmente o vale-transporte;

- oferecer alguma contribuição financeira para aqueles que aderirem ao projeto como, pagar estacionamento, o combustível, entre outros e

- mostrar que o excesso de carros nas ruas pode causar doenças por meio da poluição do ar, que faz mal à saúde.

2 - Para os gestores de municípios, com destaque para a cidade de São Paulo.

Muitas ações poderão ser planejadas e realizadas, tais como:

- Criar políticas públicas que atendam as necessidades da população, em relação ao trãnsito na cidade;

- fazer com que a população participe ativamente das propostas de mudança em relação à mobilidade nas cidades;

- melhorar e investir no transporte público motorizado de massa: ônibus, trens, metrô e transportes não motorizados: bicicleta;

- construir corredores de ônibus eficientes e criar faixas exclusivas para motocicletas; 
- aumentar o número de transportes nos horários de pico, e propor rotas alternativas;

- expandir com rapidez a malha metroviária;

- organizar integração com ônibus, metrô, trens e automóveis participantes do programa de Carona Solidária;

- aumentar o número de placas nos dias de rodízio;

- investir na concepção do transporte elétrico e

- construir monotrilhos e Veiculos Leves sobre Trilhos;

Todas essas ações poderão contribuir de alguma forma para um futuro melhor e um planeta mais sustentável. 


\section{8 - REFERÊNCIAS}

Albuquerque EM de. Avaliação da técnica de amostragem "Respondent-driven Sampling" na estimação de prevalências de doenças transmissíveis em populações organizadas em redes complexas. \{tese de mestrado\}. Rio de janeiro: Escola Nacional de Saúde Pública Sérgio Arouca-ENSP, Fiocruz; 2009.

Andrade MM. Introdução á metodologia do trabalho científico. 10 $10^{\underline{a}}$ ed. São Paulo: Atlas; 2010.

Aranha ML de. Martins MHP. Filosofando introdução à filosofia. $4^{a}$ ed. São Paulo: Moderna; 2009.

Assunção JV de, Malheiros TF. Poluição atmosférica. In: Philippi Jr A, Pelicioni MCF. Educação ambiental e sustentabilidade. Ed. Barueri, SP: Manole; 2009.

Barbosa L. Sociedade de Consumo. Rio de Janeiro: Zahar; 2010.

Baldin N. Munhoz EMB. Snowball (bola de neve): uma técnica metodológica para pesquisa em educação ambiental comunitária. Curitiba. 2011. www.pucpr.br/eventos/educere/educere2011/.

Bardin L. Análise de conteúdo. Lisboa: Geográfica; 2009.

Beck U. Sociedade de risco. Rumo a uma outra modernidade. São Paulo: Ed $34 ; 2010$.

Branco GM, Szwarc A, Branco FC. Programa Ambiental de Inspeção e Manutenção Veicular. São Paulo: Blucher; 2012.

Brasil. Lei № 7.418 de 16 de dezembro 1985. Instiui o vale-transporte e dá outras providências.

Brasil. Lei № 9.795 de 27 de abril de 1999. Dispõe sobre a educação ambiental, institui a Política Nacional de Educação Ambiental e dá outras providências. Diário Oficial da União. 28 maio 1999.

Brasil Lei 12.633 de 14 de maio de 2012. Institui o dia nacional da Educação Ambiental. Diário Oficial da União. 15 maio 2012. 
Bruna CG. Pirró LFS. Poluição Atmosférica. In Romero MA. Philippi Jr A. Bruna GC, Editores. Panorama Ambiental da Metrópole de São Paulo. São Paulo: Signus; 2004.

Bruna GC. Transporte e meio ambiente. In: Philippi Jr A, Roméro MA, Bruna GC, Editores. Curso de Gestão ambiental. São Paulo: Manole; 2004.

Cançado JED, Braga A, Pereira LAA, Arbex MA, Saldiva PHN, Santos UP. Repercursões clínicas da exposição à poluição atmosférica. J. Bras Pneumol. 2006; 32 (Supl 1): S5-S11.

CETESB - Companhia de Tecnologia de Saneamento Ambiental. Relatório sobre poluição do ar \{publicação na internet\}. São Paulo; 2011 \{acesso em 15 de agosto de 2012\}.

CETESB - Companhia de Tecnologia de Saneamento Ambiental. Guia de atividades didáticas sobre poluição do ar $2^{\mathrm{a}}$ edição \{publicação na internet\}. São Paulo; 2011 \{acesso em 15 de agosto de 2012\}. Disponível em http://www.cetesb.sp.org.br/gerenciamento-deriscos/Emergencia.

CET - Companhia de Engenharia de Tráfego. Boletins técnicos \{publicação na internet\} São Paulo; 2011 \{acesso em 28 de outubro de 2012\}. Disponível em http://www.cetsp.com.br/consultas/boletinstécnicos.aspx.

Chiesa $A M$ et al. A Construção de tecnologias de atenção em saúde com base na promoção da saúde. Ver. Esc. Enfermagem USP. 2009.43 (Esp2): 1352-7 www.ee.usp.br/reeusp.

Christianini WAC, Hagiwara SS. Operação de trânsito um desafio permanente. Boletim Técnico CET 44. Disponível www.cetsp.com.br/média/56369/btcetsp44.pdf.

Clifford G. A Interpretação das Culturas. Rio de Janeiro: LTC; 1989.

Conselho Nacional do Meio Ambiente (CONAMA). Resolução, 1990. 
Dias GF. Educação Ambiental principios e práticas. São Paulo: Gaia; 2011.

Franco M de AR. Planejamento Ambiental para a cidade sustentável. São Paulo: Edifurb; 2001.

Freire MLR.Educação Ambiental eOperação Rodízio na cidade de São Paulo: In: Operação Rodízio como instrumento de Educação Ambiental - Seminário Internacional. São Paulo: Sonora; 1998.

Freire P. Educação e Mudança. São Paulo: Paz e Terra; 2011.

Geertz C. A interpretação das culturas. Rio de Janeiro: LTC; 2008.

Gil AC. Métodos e técnicas de pesquisa social. São Paulo: Atlas; 2010.

Gomide M, Serrão MA. A educação ambiental e a promoção da saúde. Cad. Saúde Coletiva. 2004.

Gouveia N, Mendonça GAS, Leon AP, Correia JEM, Junger WL, Freitas CU, Daumas RP, Martins LC, Giussepe L, Conceição GMS, Manerich A, Cruz JC. Poluição do ar e efeitos na saúde nas populações de duas grandes metrópoles brasileiras. (Epidemiologia e Serviços de Saúde; 2003; 12(1): 29-40).

Guerra AJT, Hasenack H, Scortegagna A. Atlas geográfico mundial. São Paulo: Fundamentos; 2006.

Guiddens A. As consequências da modernidade. São Paulo: Unesp; 1990.

Guimarães FA. Poluição do ar. São Paulo: Fundacentro; 1992.

Gullo A A S. Violência urbana: um problema social. Tempo Social; Rev. Sociol. USP, S. Paulo, 10 (1): 105-119, maio de 1998.

Hoffmann et al. Comportamento Humano no Trânsito. São Paulo: Casa do Psicólogo; 2004.

IUCN - International Union for Conservation of Nature. Managing protected areas in the tropics, switzerland, 1994. \{acessado em outubro de 2012\}. 
Jacobi P. Cidade e meio ambiente percepções e práticas em São Paulo: Annablume; São Paulo. 1999.

Uma agenda para a Rio + 20. Jornal da USP. 2011 agosto 29 a setembro 4;. Ano XXVII № 936.

Jornal Diário do Comércio. 2011 agosto 2; p 11.

Phillip Jr A, Malheiros TF. Controle do ar. In Philippi Jr A. Editor. Saneamento, Saúde e Ambiente. Fundamento para um desenvolvimento sustentável. Barueri, SP: Manole; 2005.

Kemp DD. Global Environmental Issues: A Climatological. Londres, 1994.

Laraia RB. Cultura um conceito antropológico. Rio de Janeiro: Zahar; 2009.

Layrargues PP. Complexidade e a releitura do significado da educação ambiental. In Loureiro et al. Organizadores. Repensar a Educação Ambiental: um olhar crítico. São Paulo: Cortez; 2009.

LPAE - Laboratório de poluição Atmosférica Experimental da Faculdade de Medicina da Universidade de São Paulo. São Paulo, 2007.

Leff E. A complexidade ambiental. São Paulo: Cortez; 2003.

Leonard A. A história das coisas. Da natureza ao lixo, o que acontece com tudo que consumimos. São Paulo: Zahar; 2010.

Lipp M. Rocha JC. Stress, Hipertensão arterial e Qualidade de Vida, Campinas, SP: Papirus; 1996.

Luzzi D. Educação e meio ambiente uma relação intrínseca, Barueri, SP: Manole; 2012.

Martins LC, Latorre MRDO, Cardoso MRA, Gonçalves FLT, SALDIVA PHN, Braga ALF. Poluição atmosférica e atendimento por pneumonia e gripe em São Paulo, Brasil Ver Saúde Pública 2002; 36 (1): 88-94 www.fsp.usp.br/rsp.

McCormick J. Rumo ao paraíso: a história do movimento ambientalista. Rio de Janeiro: Relume-Dumará; 1992. 
Medina NM. Os Desafios da Formação de Formadores para a Educação Ambiental. In Philippi JR A. Pelicioni MCF. Editores. Educação Ambiental: Desenvolvimento de Cursos e Projetos. São Paulo: Signus; 2000.

Mendonça R. Como Cuidar do seu Meio Ambiente. São Paulo: BEl; 2010.

Ministério da Saúde. Promoção da Saúde: Carta de Ottawa, Brasília, 1996.

Ministério da Saúde. Portaria no 687, de 30 março de 2006. Aprova a Política Nacional de Promoção da Saúde.

Minayo MCS. O Desafio do Conhecimento: Pesquisa Qualitativa em Saúde. São Paulo: Hucitec; 2010.

Morin E. Os Sete Saberes Necessários à Educação do Futuro. Brasília: Cortez; 2005.

Natal D. Fundamentos de Saúde Pública. In: Philipp Jr A, Roméro MA, Bruna GC. Curso de Gestão Ambiental. Barueri, SP: Manole; 2004.

Odum EP. Ecologia. Guanabara Koogan S.A. 1988.

Oliveira SC. Educação Ambiental com Vistas a um Trânsito Saudável. \{Trabalho de Conclusão do Curso de Especialização\}. São Paulo: Faculdade de Saúde Pública da USP; 2010.

Oliveira RDF, Alves JWS. Cadernos de Educação Ambiental Mudanças Climáticas Globais no Estado de São Paulo: 2011.

OMS. Mudança Climática e Saúde Humana - Riscos e Respostas: Sumário Revisado 2009 www.opas.org.br visitado em 10 de outubro de 2012.

Ortigoza S A G. Cortez A T C. Da Produção ao Consumo: Impactos Socioambientais no Espaço Urbano. São Paulo: Unesp; 2009.

Pasternak S. Leme MCS. De Vila a Metrópole. In Saldiva et al. Meio Ambiente e Saúde: O Desafio das Metrópoles. São Paulo: Exlibris; 2010. 
Pelicioni MCF. Educação em Saúde e Educação Ambiental Estratégias de Construção da Escola Promotora da Saúde. \{Tese de livre-docência\}. São Paulo: Faculdade de Saúde Pública da USP; 2000.

Pelicioni MCF. Fundamentos da Educação Ambiental. In: Philipp Jr A, Roméro MA, Bruna GC. Curso de Gestão Ambiental. Barueri, SP: Manole; 2004.

Pereira et al. O Ar da Cidade, Ruído e as Desigualdades na Saúde. In: Saldiva PHN et al. Meio Ambiente e Saúde: O Desafio das Metrópoles. São Paulo: ExLibris; 2010.

PNUMA - Programa das Nações Unidas para o Meio Ambiente. Mude o hábito: um guia da ONU para a neutralidade climática. ISBN 978-82-7701-073-1, Arendal, 2008.

Poluição é a "pior já registrada" em Pequim. \{homepage na internet\}. São Paulo: Greenpeace 2013; \{acesso em 13 maio 2013\}. Disponível em: http://ultimossegundo.ig.com.br/ciencia/meioambiente/2013-01-13/poluicao-e-epior-ja-registrada-em-pequim-diz-greenpeace.html.

Programa Cidades e Soluções, exibido em 05/2009. www.globonews/programacidadesesoluções.com \{acessado em 15 de junho de $2011\}$.

Programa Cidades e Soluções, exibido em 21/12/2011. www.globonews/programacidadesesoluções.com \{acessado em 27 de janeiro de 2012\}.

Reigota M. Educação Ambiental: Fragmentos de sua História no Brasil. In Noal FO. Reigota M. Barcelos VHL. Organizadores. Tendências da Educação Ambiental Brasileira. Santa Cruz do Sul, RS: Edunisc; 1998.

Reigota M. Ecologistas. Santa Cruz do Sul, RS: Edunisc; 1999.

Reigota M. O que é Educação Ambiental. São Paulo: Brasiliense; 2009.

Reigota M. Meio Ambiente e Representação Social. São Paulo: Cortez; 2010. 
Reis VC, Pinheiro JF, Lima CO. Projetos de Educação Ambiental na Área de Transportes Urbanos em São Paulo. In: Philipp Jr A, Pelicioni MCF. Educação Ambiental Desenvolvimento de Cursos e Projetos. São Paulo: Signus; 2002.

COP 18: Kyoto renovado e pouco compromisso. RADIS. 2013; (124): 5.

Revista Vida Simples. 2011; (105): 19.

Rezende PTV, Souza PR. Mobilidade Urbana nas Grandes Cidades Brasileiras: Um estudo sobre os Impactos do Congestionamento. XII SIMPOI; FGVEAESP. São Paulo: 2009.

Richardson RJ et al. Pesquisa Social Métodos e Técnicas. São Paulo: Atlas; 2012.

Sant`Anna ETG. Efeito da Poluição Atmosférica Urbana sobre o Epitélio Respiratório de Ratos Eutróficos e Desnutridos. \{Tese de mestrado\}. São Paulo: Escola Paulista de Medicina da UFSP; 1996.

Sauvé L. Educação e Meio Ambiente: Construir a Esperança sem Ingenuidade. In Ziaka Y. Souchon C. Robichon P. Editores. Caderno de Proposições para o Século XXI: Educação Ambiental seis Proposições para Agirmos como Cidadãos. São Paulo: Polis; 2003.

Seade. Frota total de veículos. Região metropolitana de São Paulo. 2009. Disponível em http://www.seade.gov.br/produtos/imp/index.php?page=tabela.

Sema - Secretaria Estadual de Meio Ambiente. Debatendo a poluição do ar. \{publicado na internet\}. São Paulo; 1997 \{acesso em junho de 2012\}. Disponível em http://www.ambiente.sp.gov.br/wpcontent/uploads/cea/debatendo.pdf.

Severino AJ. Metodologia do Trabalho Científico. 23a ed. Revisada e atualizada. 5ํㅗㄹ reimpressão. São Paulo: Cortez; 2010.

Sparti SCM, Educação para o Trânsito como Desenvolvimento de Consciência: um Estudo com Universitários/as. \{Tese de doutorado\}. São Paulo: Pontifícia Universidade Católica de São Paulo (PUC); 2003. 
Szwarc A. et al. Mobilidade Sustentável: Realidade e Desafios. In Saldiva PHN et al. Meio Ambiente e Saúde: o Desafio das Metrópoles. São Paulo: Exlibris; 2010.

Stap WB. et al The Concept of Environmental Education The Journal of Environmental Education, v1 oㅜ 1, 1989.

Sumário Revisado OMS. Mudança Climática e Saúde Humana - Riscos e Respostas. Brasília. 2008.

Tanaka S. 2010 Mudanças Climáticas. São Paulo: SM; 2011.

Toledo GIFM de. Avaliação da Exposição da População à Poluição relacionada ao Tráfego no Município de São Paulo. \{tese de doutorado\}. São Paulo: Faculdade de Saúde Pública da USP; 2010.

Toledo RF de. Educação Ambiental em Unidades de Conservação do Estado de São Paulo. \{dissertação de mestrado\}. São Paulo: Faculdade de Saúde Pública da USP; 2002.

Toledo RF de. Educação, Saúde e Meio ambiente: Uma Pesquisa Ação no Distrito de lauaretê do Município de São Gabriel da Cachoeira/AM. \{tese de doutorado\}. São Paulo: Faculdade de Saúde Pública da USP; 2006.

UNCSD - United Nations Conference on Sustainable Development. \{publicação na internet\}. \{acessado em 2012\}. Disponível em http://www.uncsd 2012.org.

Vasconcelos EA. O que é Trânsito. Coleção primeiros passos. $3^{\text {a }}$ edição, revisada e ampliada, São Paulo: Brasiliense; 1998.

Vasconcelos EA. Transporte Urbano nos Países em Desenvolvimento: Reflexões e Propostas, São Paulo: Unidas; 1996.

Wikipédia - Enciclopédia livre \{acessado em 08 de janeiro de 2013\}. Disponível em http://pt.wikipedia.org/wiki/Escala Likert.

WHO - World Health Organization. Air quality guidelines \{online\}. Genebra; 1999. Disponível em http://www.who.int/peh/air/airindex.htm. 
Zacarias R. "Sociedade de Consumo", Ideologia do Consumo e as Iniquidades Socioambientais dos Atuais Padrões de Produção e Consumo. In In Loureiro et al. Organizadores. Repensar a Educação Ambiental: um olhar crítico. São Paulo: Cortez; 2009.

Ziaka Y. Souchon C. Robichon P. Educação Ambiental: Seis Proposições para Agirmos como Cidadãos. São Paulo: Polis; 2003.

http://www.rio20.info/2012/noticias-2/rio20-em-numeros.

http://www.sinaldetransito.com.br/curiosidades foto.php?IDcuriosidad $\underline{\mathrm{e}=38}$ 


\section{COMITE DE: ETICA EM PLSQUISA - COEP \\ Faculdade de Saúde Pública Universidade de São Paulo}

OF.COEP $/ 412 / 11$

25 de novembro de 2011

Prezadas pesquisadora e orientadora,

O Comitê de Ética em Pesquisa da Faculdade de Saúde Pública da Universidade de São Paulo, em sua 9.a/11 Sessão Ordinária, realizada em 18/11/2011, analisou de acordo com a Resolução n. 196/96 do Conselho Nacional de Saúde e suas complementares, o protocolo de pesquisa n. 2301, intitulado "EDUCAÇ̃̃O AMBIENTAL. PARA A PROMOÇÃO DA SAÚDE COM TRÂNSITTO SAUDÁVEL", do grupo III, sob responsabilidade da pesquisadora Sandra Costa de Oliveira e orientação da Professora Maria Cecilia Focesi Pelicioni, considerando-o APROVADO.

Cabe lembrar que, de acordo com a Res. CNS 196/96, são deveres do(a) pesquisador(a): 1) Comunicar de imediato qualquer alteração no projeto e aguardar manifestação deste Comitê de Ética em Pesquisa para dar continuidade à pesquisa; 2) Manter sob sua guarda e em local seguro, pelo prazo de 5 (cinco) anos, os dados da pesquisa, contendo fichas individuais e todos os demais documentos recomendados pelo COEP, no caso eventual auditoria; 3). Comunicar formalmente a este Comitê por ocasião do encerramento da pesquisa; 4) Elaborar e apresentar relatórios parciais e final; 5) Justificar perante o COEP interrupção do projeto ou a não publicação dos resultados.

Atenciosamente

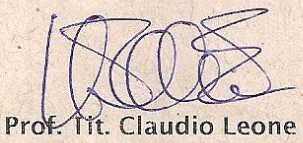

Prof. Tit. Claudio Leone

Coordenador do Comitê de Ética em Pesquisa - FSP/USP

$11 \mathrm{~m} .^{\mathrm{a}} \mathrm{Sr}{ }^{\mathrm{a}}$

Prof. a Assoc. Maria Cecilia Focesi Pelicioni

Departamento de Prática de Saúde Pública

Reubids: Guviane

Faculdade de Saúde Pública da USP

Av. Dr. Arnaldo, 715 - Cerqueira César - CEP 01246-904 - São Paulo - SP Contato:(5511)30617779 | coep@fsp.usp.br | www.fsp.usp.br 


\section{ANEXO II}

\section{INSTITUTO DO CANCER DO ESTADO DE SÃO PAULO Octávio Frias de Oliveira \\ Secretaria de Estado da Saúde}

Faculdade de Medicina da Universidade de São Paulo

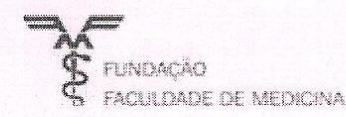

Memo ICESP - Pesquisa 1945/2011

São Paulo, 07 de dezembro de 2011

Para : Sandra Costa de Oliveira

A/C: Evelyn

Depto: Gestão de Desenvolvimento de Pessoas

Referente ao projeto - NP204/11: "Educação ambiental para a promoção da saúde com trânsito saudável"

Pesquisador responsável: Sandra Costa de Oliveira

Encaminhamos Parecer do Instituto do Câncer do Estado de São Paulo referente à solicitação de execução do projeto supracitado no ICESP para que seja encaminhado ao Comitê de Ética em Pesquisa.

Por gentileza, após aprovação/ciência do Comitê de Ética em Pesquisa, solicitamos que nos envie os documentos citados abaixo:

- Envio da carta de aprovação/ciência do CEP referente a participação do ICESP;

- Cópia dos Relatórios Semestrais/Final e publicação;

Por gentileza, protocolar esta carta confirmando o recebimento e enviar por fax 55 (11) 38933504

Agradecemos à colaboração e estamos disponíveis para maiores esclarecimentos.



Roberto Jun Ara

Gerente de Pesquisa

Instituto do Câncer do Estado de São Paulo- ICESP

"Octávio Frias de Oliveira"






\section{ANEXO III}

\section{INSTITUTO DO CANCER DO ESTADO DE SÃO PAULO \\ Octávio Frias de Oliveira \\ Secretaria de Estado da Saúde}

Faculdade de Medicina da Universidade de São Paulo

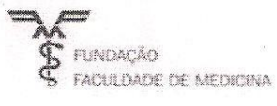

Registro: NP 204/2011

Ref. Solicitação de execução de estudo: NP 204/11 - "Educação ambiental para a promoção da saúde com trânsito saudável"

Pesquisador responsável: Sandra Costa de Oliveira

Prezado Pesquisador

CONSIDERAÇÕES

Trata-se de um estudo prospectivo com finalidade para obtenção de mestrado. 0 objetivo principal do estudo é Identificar os motivos que levam ou não as pessoas a participarem de um programa de Carona Solidária na cidade de São Paulo-SP. O Espaço do Colaborador será utilizado para aplicação do TCLE e dos questionários aos funcionários.

\section{RESPONSABILIDADES DO PESQUISADOR}

- Iniciar as atividades do estudo somente após aprovação/ciência do Comitê de Ética em Pesquisa para execução no ICESP segundo a Res. 196/96;

- Fornecer cópia da Carta de Aprovação e Relatório Semestral com ciência do CEP ao NP- ICESP;

- Enviar ao NP a publicação dos resultados do estudo;

Informamos que sua solicitação foi DEFERIDA.

Atenciosamente

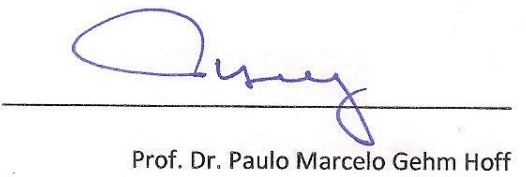

Diretor Clínico

Drof. Dr. Paulo M. G. Hoff Diresor Clínico ICESP 


\section{ANEXO IV}

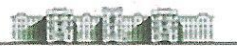 \\ MEDICINA \\ TSP \\ COMITÊ DE ÉTICA EM PESQUISA}

\section{CIÊNCIA}

O Comitê de Ética em Pesquisa da Faculdade de Medicina da Universidade de São Paulo, em 17.01.12 tomou ciência do Projeto $\mathrm{n}^{\mathrm{0}} \mathbf{0 0 1 / 1 2}$ intitulado "Educação Ambiental para a promoção da saúde com trânsito saudável.", vinculado ao ICESP, que envolverá atividade prática e/ou experimental no âmbito do Instituto do Câncer do Estado de São Paulo e que conta com prévia aprovação do Comitê de Ética em Pesquisa da Faculdade de Saúde Pública da Universidade de São Paulo, onde o projeto será executado.

Pesquisador(a) Responsável: Sandra Costa de Oliveira

CEP-FMUSP, 17 de janeiro de 2012.

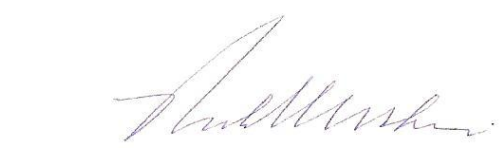

Prof. Dr. Paulo Eurípedes Marchiori

Vice-Coordenador interino

Comitê de Ética em Pesquisa

Comitê de Ética em Pesquisa da Faculdade de Medicina da Universidade de São Paulo cep.fmusp@hcnet.usp.br -3061-8004 


\section{ANEXO V}

\section{COMITE DE ÉTICA EM PESQUISA - COEP}

Faculdade de Saúde Pública Universidade de São Paulo

\section{OF.COEP/192/12}

08 de outubro de 2012

Prezadas pesquisadora e orientadora,

O Comitê de Ética em Pesquisa da Faculdade de Saúde Pública da Universidade de São Paulo, analisou, de acordo com a Resolução n. ${ }^{\circ} 196 / 96$ do Conselho Nacional de Saúde e suas complementares, o protocolo de pesquisa n. 2301 ,' intitulado "EDUCAÇÃO AMBIENTAL PARA A PROMOÇÃO DA SAÚDE COM TRÂNSITO SAUDÁVEL", do grupo III, sob responsabilidade da pesquisadora Sandra Costa de Oliveira e orientação da Professora Mária Cecilia .Focesi Pelicioni, considerando APROVADO "AD REFERENDUM" as entrevistas com os profissionais da área de saúde e ambiente utilizando a metodologia bola de neve (snowball).

Cabe lembrar que, de acordo com a Rès. CNS 196/96, são deveres do(a) pesquisador(a) 1) Comunicar de imediato qualquer alteração no projeto e aguardar manifestação dește Comitê de Ética em Pesquisa para dar continuidade à pesquisa; 2) Manter sob sua guarda e em local seguro, pelo prazo de 5 (cinco) anos, os dados da pesquisa, contendo fichas individuais e todos os demais documentos recomendados pelo COEP, no caso eventual auditoria; 3) Comunicar formalmente a este Comitê por ocasião do encerramento da pesquisa; 4) Elaborar e apresentar relatórios parciais e final; 5) Justificar perante o COEP interrupção do projeto ou a não publicação dos resultados.

Atenciosamente,

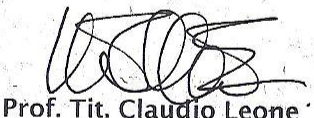

Prof. Tit. Claudio Leone

Coordenador do Comitê de Ética em Pesquisa - FSP/USP

$11 \mathrm{~m}^{\mathrm{a}} \mathrm{Sr} \mathrm{a}^{\mathrm{a}}$

Prof. ${ }^{a}$ Assoc. Maria Cecilia Focesi Pelicioni

Departamento de Prática de Saúde Pública

Faculdade de Saúde Pública da USP

Av. Dr. Arnaldo, 715 - Cerqueira César - CEP 01246-904 - São Paulo - SP Contato: (55 11) 30617779 | coep@fsp.usp.br | www.fsp.usp.br 


\section{ANEXO VI \\ TERMO DE CONSENTIMENTO LIVRE ESCLARECIMENTO \\ Questionário de Pesquisa}

Eu, Sandra Costa de Oliveira, aluna de Mestrado em Saúde Pública da Faculdade de Saúde Pública da Universidade de São Paulo (FSP/USP), sob orientação da Professora Dra Maria Cecília Focesi Pelicioni, do Departamento de Prática de Saúde Pública, pretendo desenvolver a pesquisa intitulada: Educação Ambiental para promoção da saúde com trânsito solidário que tem como objetivos:

1- Identificar os motivos que levam ou não as pessoas a participarem de um programa de Carona Solidária na cidade de São Paulo-SP.

2 - Verificar seus conhecimentos, opiniões e percepções sobre as relações entre a saúde e o meio ambiente, e em particular o uso do automóvel e a melhoria da qualidade do ar.

3 - Verificar em que medida isto irá influenciar sua decisão em participar de um programa de Carona Solidária.

Solicito por meio deste termo, o qual será elaborado em 2 (duas) vias, a sua autorização e colaboração para participar do estudo, respondendo um questionário que não necessitará de qualquer identificação de sua parte. Sua participação é livre e espontânea, responsabilizo-me por manter seus dados pessoais em sigilo, mas os resultados gerais obtidos na entrevista serão publicados. Você poderá recusar ou desistir a qualquer momento sem risco de qualquer prejuízo ou penalização. No entanto, sua participação é muito importante e enriquecerá muito esse estudo.

Obrigada desde já, qualquer que seja sua decisão. A pesquisa foi aprovada pelo Comitê de Ética em Pesquisa da Faculdade de Saúde Pública da USP FSPUSP.

Qualquer questão, dúvida, esclarecimento ou reclamação sobre os aspectos éticos dessa pesquisa, favor entrar em contato com o: Comitê de Ética em Pesquisa da Faculdade de Saúde Pública da USP - Av. Dr. Arnaldo, 715, 2oㅡ andar, Cerqueira Cesar - SP, telefone (11) 3061-7779.

Ao final da pesquisa me comprometo a apresentar os resultados para os participantes.

\section{Sandra Costa de Oliveira}

\section{Autorização}

$\mathrm{Eu}$, 
Após ler e receber explicações sobre a pesquisa, e ter meus direitos de:

1- receber resposta a qualquer pergunta e esclarecimento sobre os procedimentos, riscos, benefícios e outros relacionados à pesquisa;

2 - retirar o consentimento a qualquer momento e deixar de participar do estudo;

3- não ser identificado e ser mantido o caráter confidencial das informações relacionadas à minha privacidade;

4- procurar esclarecimento com o Comitê de Ética em Pesquisa da Faculdade de Saúde Pública da Universidade de São Paulo, no telefone 11 3061-7779 ou Av. Dr. Arnaldo, 715 - Cerqueira César, São Paulo, - SP, em caso de dúvidas ou notificação de acontecimentos não previstos. Declaro estar ciente do exposto e desejo participar da pesquisa.

São Paulo,

Nome do participante

Assinatura do participante:

Eu, Sandra Costa de Oliveira, declaro que forneci todas as informações referentes à pesquisa para o participante.

Assinatura da pesquisadora

Data:

Qualquer dúvida entrar em contato com:

Sandra Costa de Oliveira: (11) 98220-3144 ou e-mail: sandraco@usp.br 


\section{ANEXO VII}

Questionário

(folha 1)

1) Você se preocupa com o meio ambiente?

Sim ( ) Por quê?

Não ( ) Porquê?

2) Dos problemas ambientais da cidade de São Paulo quais você considera mais relevantes?

3) Você tem tido algum problema de saúde relacionado à algum problema ambiental?

3 a) Você se lembra de algum problema de saúde de alguém de sua família relacionado à algum problema ambiental?

4) Você já ouviu falar em transporte compartilhado ou Carona Solidária?

$\operatorname{Sim}($ ) O que?

Não ( )

4 a) Qual a sua opinião sobre esse assunto? (discorra).

5) Você já se cadastrou anteriormente em algum site de carona?

$\operatorname{Sim}($ ) Qual?

Não ( ) Por quê?

6) Se você se cadastrou, você indicaria este site para outras pessoas? Por quê?

7) O que é necessário em um programa de carona para que você possa sentir-se seguro?

8) Você tem carro?

$\operatorname{Sim}()$

Não ( ) 


\section{ANEXO VIII \\ TERMO DE CONSENTIMENTO LIVRE ESCLARECIMENTO}

\section{Entrevista de Pesquisa}

Eu, Sandra Costa de Oliveira, aluna de Mestrado em Saúde Pública da Faculdade de Saúde Pública da Universidade de São Paulo (FSP/USP), sob orientação da Professora $\mathrm{Dr}^{\mathrm{a}}$ Maria Cecília Focesi PELICIONI, do Departamento de Prática de Saúde Pública, pretendo desenvolver a pesquisa intitulada: Educação Ambiental para promoção da saúde com trânsito solidário que tem como objetivos:

1- Identificar os motivos que levam ou não as pessoas a participarem de um programa de Carona Solidária na cidade de São Paulo-SP.

2 - Verificar seus conhecimentos, opiniões e percepções sobre as relações entre a saúde e o meio ambiente, e em particular o uso do automóvel e a melhoria da qualidade do ar.

3 - Verificar em que medida isto irá influenciar sua decisão em participar de um programa de Carona Solidária.

Solicito por meio deste termo, o qual será elaborado em 2 (duas) vias, a sua autorização e colaboração para participar do estudo, respondendo a esta entrevista que não necessitará de qualquer identificação de sua parte. Sua participação é livre e espontânea, responsabilizo-me por manter seus dados pessoais em sigilo, mas os resultados gerais obtidos na entrevista serão publicados. Você poderá recusar ou desistir a qualquer momento sem risco de qualquer prejuízo ou penalização. No entanto, sua participação é muito importante e enriquecerá muito esse estudo.

Obrigada desde já, qualquer que seja sua decisão. A pesquisa foi aprovada pelo Comitê de Etica em Pesquisa da Faculdade de Saúde Pública da USP FSPUSP.

Qualquer questão, dúvida, esclarecimento ou reclamação sobre os aspectos éticos dessa pesquisa, favor entrar em contato com o: Comitê de Ética em Pesquisa da Faculdade de Saúde Pública da USP - Av. Dr. Arnaldo, 715, 2o andar, Cerqueira Cesar - SP, telefone (11) 3061-7779.

Ao final da pesquisa me comprometo a apresentar os resultados para os participantes.

\section{Sandra Costa de Oliveira}

\section{Autorização}

$\mathrm{Eu}$,

Após ler e receber explicações sobre a pesquisa, e ter meus direitos de:

1- receber resposta a qualquer pergunta e esclarecimento sobre os procedimentos, riscos, benefícios e outros relacionados à pesquisa; 
2 - retirar o consentimento a qualquer momento e deixar de participar do estudo;

3- não ser identificado e ser mantido o caráter confidencial das informações relacionadas à minha privacidade;

4- procurar esclarecimento com o Comitê de Ética em Pesquisa da Faculdade de Saúde Pública da Universidade de São Paulo, no telefone 11 3061-7779 ou Av. Dr. Arnaldo, 715 - Cerqueira César, São Paulo, - SP, em caso de dúvidas ou notificação de acontecimentos não previstos. Declaro estar ciente do exposto e desejo participar da pesquisa.

São Paulo,

Nome do participante

Assinatura do participante:

Eu, Sandra Costa de Oliveira, declaro que forneci todas as informações referentes à pesquisa para o participante.

Assinatura da pesquisadora

Data:

Qualquer dúvida entrar em contato com:

Sandra Costa de Oliveira: (11) 98220-3144 ou e-mail: sandraco@usp.br 


\begin{abstract}
ANEXO IX
Perguntas a serem feitas para os profissionais da área de saúde conforme sugestão da Banca de Qualificação de Mestrado em 19 de outubro de 2011, da aluna Sandra Costa de Oliveira № USP 5824512, com o tema Educação Ambiental para Promoção da Saúde com Trânsito Solidário.
\end{abstract}

Em primeiro lugar queremos agradecer sua contribuição e o aceite em participar desta pesquisa. Posso gravar nossa conversa?

1) Sabendo que o meio ambiente é um grande determinante da saúde e da doença: o Sr/Sra acha que a população em geral consegue perceber esta ligação e principalmente os fatos relacionados à poluição do ar?

2) Em sua opinião quais os benefícios que um Programa de Carona Solidária pode trazer para seus adeptos?

3) $\mathrm{O} \mathrm{Sr} / \mathrm{Sra}$ acredita que ações isoladas como o incentivo à participação de um Programa de Carona Solidária devam ser inseridas como política pública por parte do governo ou dependem apenas de uma opção pessoal?

4) A desconfiança e o medo presente nas grandes cidades seria um fator determinante para a falta de adesão ao Programa de Carona Solidária?

5) Como o Sr/Sra vê o futuro de uma cidade como São Paulo se a questão da mobilidade se mantiver como está?

6) Gostaríamos de saber sua opinião sobre o seguinte fato:

Houve a solicitação de um Hospital Público da cidade de São Paulo para que fosse implantado entre seus funcionários um Programa de Carona Solidária. Aceitamos o desafio e lá permanecemos por 6 meses. Oferecemos todas as informações disponíveis preparando-os em pequenos grupos, e colhemos sob a forma de questionário suas opiniões, seus interesses e necessidades sobre 0 assunto. No entanto, no meio do 
processo onde haviam pessoas muito entusiasmadas ocorreu um problema: circulou uma informação oficial de que quem participasse não poderia receber mais vale-transporte. Isso parece ter influenciado preponderantemente nas adesões dos interessados que acabaram limitando-se a $10 \%$ dos entrevistados, porém ninguém transformou essa idéia em ação.

Para o Sr/Sra a que isso pode ser verdadeiramente atribuído?

$\mathrm{O} \mathrm{Sr} / \mathrm{Sr}^{\mathrm{a}}$ gostaria de acrescentar mais alguma coisa?

$\mathrm{O} \mathrm{Sr} / \mathrm{Sr}^{\mathrm{a}}$ poderia me indicar outros profissionais que discutem esse assunto?

Mais uma vez grata por sua importante contribuição!

Sandra Costa de Oliveira-Mestranda da FSP (/USP)

Maria Cecilia Focesi Pelicioni - Orientadora - Prof ${ }^{\mathrm{a}}$ Associada da FSP (USP) 


\section{ANEXO X \\ FICHA DE INDENTIFICAÇÃO DOS PROFISSIONAIS ENTREVISTADOS SOBRE QUESTÕES RELACIONADAS À SAÚDE HUMANA E POLUIÇÃO DO AR}

Ficha de Identificação: 1

Nome: Prof Associado N G

Formação: Médico

Linha de Pesquisa: Epidemiologia Ambiental

Local de Trabalho: Faculdade de Medicina da Universidade de São Paulo

\section{Ficha de Identificação: 2}

Nome: Prof Titular J V A

Formação: Engenheiro

Linha de Pesquisa: Tecnologia de Controle da Poluição do ar, poluentes tóxicos, monitoramento do ar, ventilação industrial e gestão ambiental.

Local de Trabalho: Faculdade de Saúde Pública da Universidade de São Paulo

\section{Ficha de Identificação: 3}

Nome: $\operatorname{Prof}^{\mathrm{a}} \operatorname{Dr}^{\mathrm{a}} \mathrm{A}$ C N

Formação: Física

Linha de Pesquisa: Avaliação e Gerenciamento de Riscos Ambientais

Local de Trabalho: Faculdade de Medicina da Universidade de São Paulo

\section{Ficha de identificação: 4}

Nome: $\operatorname{Prof}^{\mathrm{a}} \mathrm{Dr}^{\mathrm{a}} \mathrm{S}$ C M S

Formação: Pedagoga

Linha de Pesquisa: Desenvolvimento de Consciência e Intervenções Psicoeducacionais

Local de Trabalho: Pontifícia Universidade Católica de São Paulo (PUC-SP) 


\section{Ficha de Identificação: 5}

Nome: $\operatorname{Prof}^{\mathrm{a}} \mathrm{Dr}^{\mathrm{a}} \mathrm{H} \mathrm{R}$

Formação: Geógrafa

Linha de Pesquisa: Estudo dos impactos à saúde decorrentes de alterações climáticas e ambientais, de queimadas de cana-de-açúcar e de mudanças na cobertura vegetal.

Local de Trabalho: Faculdade de Saúde Pública da Universidade de São Paulo

\section{Ficha de Identificação: 6}

Nome: Prof Dr P H N S

Formação: Médico Patologista

Linha de Pesquisa:

Local de Trabalho: Faculdade de Medicina da Universidade de São Paulo

\section{Ficha de Identificação: 7}

Nome: $\operatorname{Prof}^{\mathrm{a}} \operatorname{Dr}^{\mathrm{a}} \mathrm{E}$ T G

Formação: Bióloga

Linha de Pesquisa: Meio ambiente mutagênese ambiental, poluição atmosférica e bioindicadores vegetais.

Local de Trabalho: Faculdade de Medicina da Universidade de São Paulo

\section{Ficha de Identificação: 8}

Nome: $\operatorname{Dr}$ G M B

Formação: Engenheiro

Linha de Pesquisa: Inspeção Veicular

Local de Trabalho: Controlar 


\section{Ficha de Identificação: 9}

Nome: Prof ${ }^{a}$ Associada W M R G

Formação: Engenheira e Socióloga

Linha de Pesquisa: Qualidade Ambiental e Saúde

Local de Trabalho: Faculdade de Saúde Pública da Universidade de São Paulo

Ficha de Identificação: 10

Nome: Prof $\operatorname{Dr} A$ B

Formação: Médico

Linha de Pesquisa: Epidemiologia ambiental

Local de Trabalho: Faculdade de Medicina da Universidade de São Paulo

\section{Ficha de Identificação: 11}

Nome: Prof ${ }^{a}$ Associada M R A C

Formação: Odontologia

Linha de Pesquisa: Doenças respiratórias em crianças e fatores de riscos ambientais

Local de Trabalho: Faculdade de Saúde Pública da Universidade de São Paulo

\section{Ficha de Identificação: 12}

Nome: Prof Dr L G

Formação: Ciências Biológicas

Linha de Pesquisa: Saneamento, promoção da saúde, indicadores de sustentabilidade ambiental e de saúde e abordagem ecossistêmica em saúde. Local de Trabalho: Faculdade de Saúde Pública da Universidade de São Paulo 
Ficha de Identificação: 13

Nome: Dr U P S

Formação: Médico Pneumologista

Linha de Pesquisa: Especialista em estudos das doenças respiratórias e mobilidade urbana.

Local de Trabalho: INCOR

Ficha de Identificação: 14

Nome: Prof $\operatorname{Dr} L A$ A P

Formação: Médico Epidemiologista

Linha de Pesquisa: Epidemiologia Ambiental

Local de Trabalho: Faculdade de Medicina da Universidade de São Paulo 
ANEXO XI

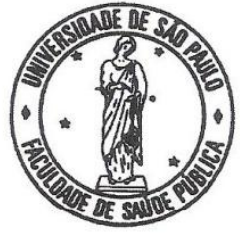

Ofício APJ \#59/11
UNIVERSIDADE DE SÃO PAULO

FACULDADE DE SAÚDE PÚBLICA

Departamento de Saúde Ambiental

Av. Dr. Arnaldo, 715 - São Paulo,SP

CEP 01246-904

Tel. (11) 3061-7118/(11) 3061-7970

São Paulo, 15 de agosto de 2011

Ref: Convite. Projeto Editorial 2a Ed. Educação Ambiental e Sustentabilidade

Confirmando entendimentos havidos, temos a satisfação de convidá-lo para participar 2a Edição do Livro Educação Ambiental e Sustentabilidade, na qualidade de autor de capítulo.

Os textos, contendo cerca de 30 páginas, devem ser inéditos, elaborados com base em estudos e pesquisas concluídos ou em andamento, que permitam contribuições ao tema. O formato recomendado é fonte Times New Roman 11, espaçamento duplo, margens laterais de $2 \mathrm{~cm}$, superior e inferior de $3 \mathrm{~cm}$. Para garantir a qualidade editorial da obra em referência, solicitamos leitura do Projeto Editorial, no qual estão identificados os objetivos, geral e das várias partes que a compõe.

Os eventuais esclarecimentos e textos produzidos devem ser encaminhados à Giuliana Talamini (editorial15@manole.com.br; Tel. (11) 3061-7118).

Objetivando atender ao cronograma de produção editorial previsto, solicitamos o encaminhamento do capítulo até 30 de agosto de 2011.

Agradecemos desde já sua participação e comprometimento.

Cordialmente,

Arlindo Philippi Jr

Maria Cecília Focesi Pelicioni 